Beggar-Thy-Neighbour Tax Cuts:

Mobility after a Local Income and Wealth

Tax Reform in Switzerland

Isabel Z. Martínez

May 2016 Discussion Paper no. 2016-08 


$\begin{array}{ll}\text { Editor: } & \text { Martina Flockerzi } \\ & \text { University of St.Gallen } \\ & \text { School of Economics and Political Science } \\ & \text { Department of Economics } \\ & \text { Bodanstrasse 8 } \\ & \text { CH-9000 St. Gallen } \\ & \text { Phone } \quad+41712242325 \\ & \text { Fax } \quad+41712243135 \\ & \text { Email seps@unisg.ch } \\ & \text { School of Economics and Political Science } \\ & \text { Department of Economics } \\ & \text { University of St.Gallen } \\ & \text { Bodanstrasse } 8 \\ \text { Publisher: } & \text { CH-9000 St. Gallen } \\ & \text { Phone +41 71 224 23 25 } \\ & \text { Fax }+41712243135 \\ & \text { http://www.seps.unisg.ch }\end{array}$




\title{
Beggar-Thy-Neighbour Tax Cuts: Mobility after a Local Income and Wealth Tax Reform in Switzerland ${ }^{1}$
}

\author{
Isabel Z. Martínez
}

Author's address:

\author{
Isabel Z. Martínez \\ Schweizerisches Institut für Aussenwirtschaft und Angewandte \\ Wirtschaftsforschung \\ SIAW-HSG \\ Bodanstr. 8 \\ $\mathrm{CH}-9000$ St. Gallen \\ Email_isabel.martinez@unisg.ch \\ Website www.isabelzmartinez.com
}

\footnotetext{
${ }^{1}$ I thank Alan Auerbach, Aline Bütikofer, Emmanuel Saez, Lukas Schmid, Arthur Seibold, Pedro Souza, Charles Varner, Danny Yagan, Cristobal Young, Josef Zweimüller, and Seminar participants at UC Berkeley, the NARSC Annual Meeting in Portland, OR, and the AER Annual Meeting 2016 for fruitful discussions and helpful comments. Special thanks go to Marianne Nufer and Reto Achermann from the Cantonal Tax Administration of the Canton of Obwalden in Sarnen, as well as Ben Jann and Reto Föllmi, who helped obtaining access to the data for this project. The Tax Administration of the Canton of Obwalden allowed me to access the individual tax data, making this research possible. Individual federal income tax data have been made accessible within the SNSF Sinergia Project No. 130648 'The Swiss Confederation: A Natural Laboratory for Research on Fiscal and Political Decentralization". This work has benefited from financial support through the SNSF Doc.Mobility grant No.158823.
} 


\begin{abstract}
Tax competition raises the question to which extent taxpayers respond to differences in income tax rates by migrating to low-tax areas. This paper analyzes a large, two-step tax reform in the canton of Obwalden in central Switzerland in 2006 and 2008. The canton first introduced a regressive income tax scheme with the explicit purpose of attracting affluent taxpayers, followed by a flat rate tax, thereby lowering taxes for all taxpayers. DiD estimations comparing Obwalden and two neighboring cantons confirm that the reform was successful in increasing the canton's tax base by increasing the share of rich and their average income. Using individual tax data I apply a 2SLS approach to estimate how responsive migration was to the tax reduction. I find an elasticity of the stock of rich taxpayers in the canton with respect to the average net-of-tax rate of 1.9-2.4. The elasticity of the inflow of rich taxpayers is even larger, ranging from 5 to 12. These large elasticities can be explained by (i) the large pool of intentionally treated in the present institutional setting, which puts almost no restrictions on taxpayers to take advantage of the low tax, and (ii) the initially low share of rich taxpayers in Obwalden combined with the small size of the canton. A small number of rich taxpayers relocating therefore translates into a large elasticity. DiD estimates of cantonal revenue, however, suggest that the tax cuts despite attracting and retaining a substantial number of rich taxpayers, did not lead to an increase in cantonal tax revenue.
\end{abstract}

\title{
Keywords
}

Tax-induced mobility; Personal income tax; Local taxes; Tax competition; Elasticity of taxable income ETI.

\section{JEL Classification}

$H 71, H 73, R 23, H 31, H 24$. 


\section{Introduction}

In the presence of tax competition, governments are concerned about the drain of their tax base to other, low-tax regions. While in the 1990s the focus has been on capital income taxation, lately concerns are also about top income earners evading taxes by relocating to tax havens. The topic has gained large political attention, fueled by media coverage on prominent examples of sport stars, singers, and actors living in places like Switzerland or Florida, or, more recently, Gérard Depardieu who officially moved from France to Russia in response to an increase in taxes in France.

These prominent examples focus on a very special group of 'workers', who are particularly mobile. From the literature on top incomes, however, we know that the group of the top $1 \%$ consists of more than just stars from the sports and entertainment world, but encompasses CEO's, self-employed, and high-earning professionals. On economic grounds little is known about the extent to which these taxpayers relocate to low-tax regions to benefit from low taxes. I address this question by analyzing a regressive income tax reform in central Switzerland, which explicitly aimed at attracting rich taxpayers.

Gaining a better understanding of the channels through which taxpayers respond to taxation is crucial for the design of optimal tax policies. Moreover, these questions will even gain importance in the future, since tax competition is likely to intensify, as labor is becoming more mobile. This is due to continuing advances in transportation and communication technologies, making it easier for people to live and work in different places, as well as to political reasons such as the European Integration, reducing migration costs.

I exploit quasi-experimental variation created by the regressive income tax reform in the Swiss canton of Obwalden in 2006, which provides an ideal setting to study taxinduced mobility of taxpayers. I present new evidence that the elasticity of the number of rich taxpayers with respect to the average net-of-tax rate is large, and that taxpayers are more responsive to tax competition than prior results suggested so far. In the present institutional setting we are able to observe such large effects partly because certain limitations on tax-optimizing behavior are absent. Mainly, the prevalence of residence-based taxation as opposed to source-based taxation allows taxpayers to shift their tax burden without shifting their economic activities.

In December 2005 the Swiss canton of Obwalden passed a tax reform by popular vote. As of January 1 2006, incomes were to be taxed progressively up to taxable incomes of 300,000 CHF, but then marginal tax rates started declining again, and so did average 
taxes. This regressive income tax scheme affected roughly the top 1\% of Swiss taxpayers. All that was needed to take advantage of the regressive income tax, was to relocate to the canton of Obwalden, since in Switzerland residence-based taxation applies. Furthermore, it is residency at the end of the year which determines the tax liability for the whole calendar year, such that taxpayers had about 12 months to move to Obwalden and still benefit from the tax scheme in 2006 already. Since the Swiss tax code does not draw any distinction between labor and capital incomes, high-paid employees could take advantage of the scheme as well as self-employed and rentiers.

I analyze the effect of the reform using two different, complementary approaches. Using federal income tax data, aggregated at the municipality level, I first compare Obwalden to its two neighbors, Lucerne and Nidwalden, in a Difference-in-Differences (DiD) setting. The former is a large canton with an urban center, but with tax rates similar to those in Obwalden prior to the reform. Nidwalden on the other hand is, like Obwalden, a small canton with no big economic center, but tax rates in Nidwalden had always been lower than in Obwalden before the reform. With the reform, Obwalden matched Nidwalden's low tax rates.

I compare two outcomes in these cantons' municipalities: (i) the share of rich taxpayers before and after the reform, and (ii) net income per taxpayer. The results indicate that the reform had the intended effect, increasing the share of rich taxpayers by either attracting and / or retaining them in the canton. Compared to its neighbors, the share of rich taxpayers in Obwalden grew by $24-30 \%$. This is also reflected by an estimated average increase in net income per taxpayer of $16 \%$ as a result of the reform. Income growth, however, is concentrated among the rich taxpayers. The reform had no effect on measured net incomes of taxpayers below the regressive threshold.

Descriptive statistics based on the federal income tax data further show that after 2005 the share of rich taxpayers in Obwalden increased remarkably, and much more so than in any other canton in Switzerland. This again indicates that the reform had an effect on the number of rich taxpayers living in the canton, and that it is unlikely that the top $1 \%$ in Switzerland experienced a positive exogenous income shock which happened to coincide with the reform in Obwalden.

To shed more light on taxpayers' responses to this reform, I use individual income tax data from the canton of Obwalden for the period 2001-2010 ${ }^{1}$ Descriptive results show that the responses in terms of inflows have been of an immediate nature. Average and

\footnotetext{
${ }^{1}$ This data has been made available by the cantonal tax administration of the Canton of Obwalden in Sarnen. Many thanks go to Marianne Nufer and Reto Achermann from the tax administration of the Canton of Obwalden, as well as to Ben Jann and Reto Foellmi, who helped obtaining the data for this project.
} 
median income and wealth of those who moved-in immediately after the introduction of the regressive tax are higher than before, and average income and wealth of the in-comers in this period were also higher than those of the residents.

In a second step I estimate the elasticity of rich taxpayers in the canton to the average net-of-tax rate (this is: one minus the average tax rate), with a Two-Stages Least Squares (2SLS) approach using individual income tax data from Obwalden. The observed tax rate change may be endogenous to the number of rich taxpayers, if tax cuts came as a response to a few number of high income earners already living in the canton. To isolate the effect of the reform on the number of rich taxpayers, I instrument the net of tax rate with the DiD treatment interaction dummy. Treated taxpayers are those falling in the regressive part of the tax scheme. I define as control group rich taxpayers with taxable incomes slightly below the regressive threshold. In the second stage I regress the log of taxpayers on the $\log$ of the tax rate instrument. I find an elasticity of 1.9 to 2.3 with respect to the stock of rich taxpayers. With respect to the in-flow of rich taxpayers I find even larger elasticity of up to 11.8 in the short-run and 9.7 in the first five years after the reform. These estimates are very large, compared to Kleven et al. (2014), who find an elasticity of 1.5-2 for high-income foreigners working in Denmark.

This paper contributes to the literature on tax-induced mobility and local public finance. Even though the question of moving responses to taxation or the provision of public goods has been considered in the public finance literature ever since Tiebout's (1956) model of local provision of public goods, the empirical literature investigating taxinduced mobility has started to grow only recently with register data becoming available for research. The work by Kleven et al. $(2013,2014)$ is the only one to my knowledge that studies tax-induced mobility and and estimates corresponding elasticites. Both studies find large migratory responses of European football players and high-income foreigners in Denmark, respectively. These, however, are quite specific and special groups of workers. Young and Varner (2011) as well as Young et al. (2014), who use individual income tax data for the U.S., in contrast, only find minor evidence that the rich elites move due to lower taxes.

The present study adds to this literature by looking at a tax reform meant to attract new taxpayers from within the country as well as from abroad, where no restrictions on citizenship or income source apply for eligibility of the tax scheme. I show that if the pool of intentionally treated is large and the region trying to attract rich taxpayers is relatively poor and small, the magnitude of the estimated elasticity is very large. In such a setting, even the introduction of a regressive income tax allows for potentially large 
gains for a region engaging in fierce tax competition. Key to this finding is the prevalence of residence-based taxation, as opposed to source-based taxation. This paper shows that in such a setting the responses by taxpayers are large, implying potentially high costs for the jurisdictions which lose out on their tax base.

In addition, this is the first paper to use individual panel data from tax returns to address these questions in the Swiss context, where international as well as sub-national tax competition have a long tradition. Switzerland has proven to be an ideal laboratory to study effects of local tax changes due to its strong federal character. The findings of my study nevertheless have implications beyond Switzerland. Other states, such as the U.S., allowing for tax competition at the state or metropolitan area level, give rise to corresponding behavioral responses of the citizens. The European Union is another example of how economic integration and liberalization of labor markets and migratory policies on the one hand, may conflict with the fiscal power autonomous nation states have over their citizens on the other. Even though within the European context mobility costs are higher than within Switzerland, these considerations still matter for households living in border regions, and, more generally, for high income earners who are known to be more mobile - even those who are not sport stars or famous actors.

The remainder of this paper is organized as follows. Section 2 gives an overview of previous research on tax mobility. Section 3 describes the tax reform in Obwalden. In Section 4, I present a simple model of how individuals can react to local differences and changes in taxation. The two data sets used in this study are presented in Section 5 along with some first descriptive evidence on the effects of the reform. In Section 6 I present DiD estimations comparing Obwalden to its two neighbors Lucerne and Nidwalden. Section 7 presents the 2SLS estimation strategy and the elasticity results based on the data from the canton of Obwalden. Section 8 concludes.

\section{Mobility of Individuals in Response to Taxation}

A substantial body of the empirical literature on mobility responses to taxation is based on data from Switzerland, which due to its federal structure with substantial tax setting competences on the cantonal and municipal levels has long served as a natural laboratory to study tax related questions. Furthermore, its small size and well-developed infrastructure keep mobility costs and cultural differences low - at least within cantons. Based on aggregate data, Kirchgässner and Pommerehne (1996), Feld and Kirchgässner (2001) and Schaltegger et al. (2011) find evidence supporting the hypothesis that there is income 
segregation across cantons or municipalities, respectively. This seems to be especially true for high-income earners. While studies based on aggregate data give insights about the main correlates of the allocation patterns of households, they may suffer from reverse causality. A municipality with a large share of high-income households can implement a lower tax rate but still raise the same tax revenue per capita as a municipality with only a small share of high-income households.

To avoid this issue, Liebig et al. (2007) and Schmidheiny (2006) use individual level data from Switzerland. Both studies regress the moving probability of a household on different individual and municipality characteristics. The advantage of using individual data is that from the perspective of the individual, local tax rates can be seen as exogenously given, thereby circumventing potential endogeneity affecting the estimates based on aggregate data. Schmidheiny (2006) develops an extensive location choice model, which translates neatly into conditional and nested logit models for empirical estimation. He finds that for relocating households in the area of Basel in 1997, low tax levels attract high income individuals. This is only partly explained by progressivity. Rather the results suggest that the rich prefer low taxes to a greater extent than explained by the tax schedule and that households tend to choose locations close to similar households. He therefore finds the hypothesis of income segregation confirmed.

Liebig et al. (2007), who use data from the Swiss census in 2000, look more specifically into tax rate changes between 1995 and 2000 in the roughly 700 largest Swiss municipalities. However, they do not reach such a strong conclusion as Schmidheiny (2006). They find migratory responses to be small and concentrated among Swiss college graduates. The authors explicitly address the problem of potential endogeneity by first regressing out-migration from a municipality between 1995-2000 on tax changes in the period 1990-1995, and then regressing tax changes in 2000-2005 on the out-migration in the former five-year period. According to the authors, reverse causation seems negligible. A shortcoming of the census data is that income is not covered, a problem the authors try to overcome estimating Mincer-type wage regressions. This income measure is far from perfect, as the $R^{2}$ is about $56 \%$ and because capital incomes, which are taxed together with labor incomes, cannot be taken into account. It is of crucial importance, however, to include capital incomes, since households deriving income from capital rather than labor presumably face lower mobility costs. Another caveat of the census data is that it only reveals the place of residence in 1995 and 2000, not specifying the point in time of moving and whether the household has moved more than once.

Recent studies on migratory responses to tax changes from other countries rely on 
natural experiments. Young and Varner (2011) examine the migratory responses to a substantial ex post increase in the top marginal tax rate of 2.6 percentage points in the state of New Jersey in 2004. As New Jersey lies in the New York metropolitan area, it is easy to move to one of the three other states in the metropolitan area and still commute to the same job. Using a DiD model of out-migration, they find only small migratory responses of the affected group and therefore conclude "that, at least in terms of the migration response to state income taxes, the rich are not differentthey seem to have much the same non-response as the general population" (Young and Varner, 2011, p.278). In a follow-up study using nation-wide individual tax records with a panel dimension for the period 1999-2011, Young et al. (2014) test the two hypotheses of whether millionaires move around to get the cheapest tax rate, or whether they are embedded elites with location-dependent social capital they need to do business and make income against each other. They find limited evidence of millionaire tax flight across the US, and therefore conclude that rich taxpayers are part of the elite who possess valuable social capital which is location dependent. Millionaire migration is responsive to top income tax rates, but this effect is completely driven by Florida. A border-region analysis does not suggest that clustering happens on lower-tax side of the borders. Kleven et al. (2014) investigate the effects of a preferential tax scheme for high-income expats in Denmark. Similar as in the case I study here, tax cuts in Denmark where introduced to attract high income earners, but this was limited to foreigners. The authors find that the scheme had a very large effect on the number of high-income foreigners in the country and estimate an elasticity between 1.5 and 2. In another paper, Kleven et al. (2013) analyze the migratory responses of European football players between the top 14 leagues and find that differences in the tax regime plays an important role in the decision to move: "[t]he elasticity of the number of foreign players with respect to the net-of-tax rate on foreigners is around one, and even larger for the highest-quality players" (Kleven et al., 2013, p.1922). The authors argue that being an extremely mobile group of 'workers', these estimates should be interpreted as an upper bound on the tax-induced migratory responses in the labor market as a whole. My results show that this is not necessarily true and that mobility elasticities may well be larger, even for regular high income taxpayers.

\section{Income and Wealth Tax Reform in Obwalden}

In 2006, the canton of Obwalden introduced a regressive tax schedule with marginal rates declining at taxable incomes above 300,000 CHF, and at taxable wealth of 5 million CHF. 
The aim explicitly was to attract high-income and wealthy individuals and to keep up with the competitive tax rates of the neighboring cantons, especially Zug, Nidwalden and Schwyz, which have long been known for their low tax rates on high incomes and wealth (for a political map of Switzerland including the differences in average tax rates across cantons and municipalities, see Figure B1 in the Appendix). Since 1999, Obwalden had been ranked among the high-tax cantons for taxes on personal income and wealth, ranking first in the years $2002-2005 .^{2}$

In order to lower the overall tax load, the cantonal parliament suggested a two-step tax strategy. The first step was to strengthen its position by actively engaging in intercantonal tax competition for high-income taxpayers and firms. In a second step in the near future, the overall tax load was to be lowered. ${ }^{3}$ Due to its geographic location in the heart of Switzerland and the small size of the country, mobility costs are low and commuting times to urban centers like Lucerne, Zug and Zurich lie within a reasonable range of one hour or less (see Figure B2 in the Appendix for an overview of the commuting distances and population densities in urban agglomerations). Therefore it seemed feasible to attract high-income taxpayers even if their workplace was outside Obwladen.

Initial losses in tax revenue were to be financed through exceptional payouts each canton had received from large gold sales by the Swiss National Bank in 2005. Most cantons have used this money to reduce their debts, sometimes combined with (future) tax reductions. Obwalden was no exception to this, the only difference being the dramatic size in tax cuts for the rich. The 134.5 million CHF Obwalden received form the Swiss National Bank were used to repay debt and reduce debt service. In addition, the canton made a capital provision of 23.5 million CHF to finance initial losses in municipalities' tax revenue over the first five years.

The introduction of the regressive tax scheme had been decided by the cantonal parliament in October 2005 with 39 against 4 votes, and the mandatory popular referendum to confirm the act was held on December 11 2005. The new tax law was accepted by clear majority of $86 \%$. The scheme immediately became effective as of January 12006 . However, to take advantage of the low taxes it was sufficient to officially reside in Obwalden as of December 31 2006, since in Switzerland this is the reference date defining the location of the tax liability. Hence, individuals from other cantons had roughly 12 months to consider a relocation to Obwalden. The tax strategy was accompanied by improvements

\footnotetext{
${ }^{2}$ This was mainly due to the high tax load on low-income taxpayers, since there was no personal exemption and an additional per capita tax. Source: "Steuerbelastung nach Kanton, Gesamtindex 1999-2006", BfS.

${ }^{3}$ This argumentation was shared with the voters in the official information material for the popular referendum on the new tax law: "Abstimmungsbotschaft Kantonale Volksabstimmung vom 11. Dezember 2005", Kanton Obwalden.
} 
in spatial planning and lower rates for imputed rents to increase the attractiveness of real estate in Obwalden.

Starting in October 2005, the proposal and the introduction had gained large media attention in the whole country and this attention grew considerably once the introduction had been decided upon at the ballot. ${ }^{4}$ Left-wing politicians all over the country protested heavily against this new tax law and took the matter to the Federal Court. The plaintiffs saw the principle of proportional taxation according to one's ability to pay, and the principle that taxes should be general and equal in nature, violated. The canonical view in the media and academia, however, was that the Federal Court had no say in this and was not going to rule, due to the large set of rights the constitution guarantees to cantons in taxation matters. Furthermore, in a similar case in the canton of Schaffhausen in 2004 (which had gone by surprisingly unnoticed) the same court had rejected the appeal. ${ }^{5}$ It therefore came as a surprise for many observers as well as for the President of the Cantonal Conference of Financial Directors ${ }^{6}$ when on June 12007 the court essentially ruled in favor of the plaintiffs. ${ }^{7}$ Thus the canton was obliged to change its schedule again. To guarantee legal certainty, however, the regressive schedule remained valid for the tax period of 2007. Keeping the promise of lowering taxes for everyone and offering attractive conditions for high-income households, the canton was the first to introduce a flat rate tax, with a general social exemption of 10,000 CHF, effective January $12008 .^{8}$ Again, it was sufficient for individuals to move to (or out of) Obwalden by December 31 2008 , as it is residence on the last day of the year which determines the tax liability.

Panel a) of Figure 1 depicts the changes in marginal tax rates over time exemplarily for the municipality of Sarnen. ${ }^{9}$ Income earners with incomes above 300,000 CHF taxable income benefited substantially from the tax cut in 2006 (red line), while those with incomes below that threshold faced similar or slightly lower marginal tax rates than before the change. As Panel b) of Figure 1 shows, average tax rates were reduced for

\footnotetext{
${ }^{4}$ In the large liberal newspaper Neue Zürcher Zeitung NZZ for example, there were 12 articles on taxes in Obwalden between January 12000 and October 15 2005, but 49 articles on regressive taxation in Obwalden between December 12005 and July 312007.

${ }^{5}$ See for example comments from Prof. Silvio Borner (University of Basel) and Charles Blankart (Humboldt University Berlin) in $N Z Z$ 24./25.12.2005, Georg Rich (honorary professor University of Bern and former chief economist Swiss National Bank) in NZZ 22.8.2006, and Prof. Pascal Hinny (University of Fribourg) in NZZ 22.1.2007

${ }^{6}$ Eveline Widmer-Schlumpf, NZZ 2./3.6.2007.

${ }^{7} \mathrm{BGE} 133 \mid 206$. One of the judges had in fact argued that in his view the introduction of a regressive income tax was "alarming but acceptable" given its intended temporary nature on the way to lower overall taxes in the near future (NZZ 2./3.6.2007).

${ }^{8}$ In September 2006, the Financial Director of Obwalden, Hans Wallimann, announced in an interview that the canton was planning on lowering taxes for low and middle incomes in 2009 (NZZ, 21.9.2006). The court ruling did therefore not alter the canton's original plans in a substantial way.

${ }^{9}$ The cantonal tax is multiplied by a municipality-specific tax multiplier, which is why taxes vary across municipalities. The peculiarities of cantonal and municipal level taxation in Switzerland are explained in Appendix A.
} 
all taxpayers in 2006, also for those with taxable incomes below 70,000 CHF. This is true for all municipalities in Obwalden (and especially for the municipality of Lungern), despite the differences in local tax multipliers (see Figures A2 and A3 in Appendix A for an overview of the evolution of taxes by municipality). With the introduction of the flat rate tax in 2008 (green line), it were taxable incomes below 340,000 CHF which saw a decrease in marginal rates, while incomes above that level where now again taxed at a higher rate than during the regressive period — but not as high as before the 2006 reform. This cut in marginal rates for low and middle incomes translated into lower average tax rates also for high income earners. In Sarnen the average tax rate in 2008 was only higher than in 2006 for taxable incomes above 555,100 CHF; in all other municipalities the break-even taxable income was even higher with up to 658,600 CHF in Lungern.

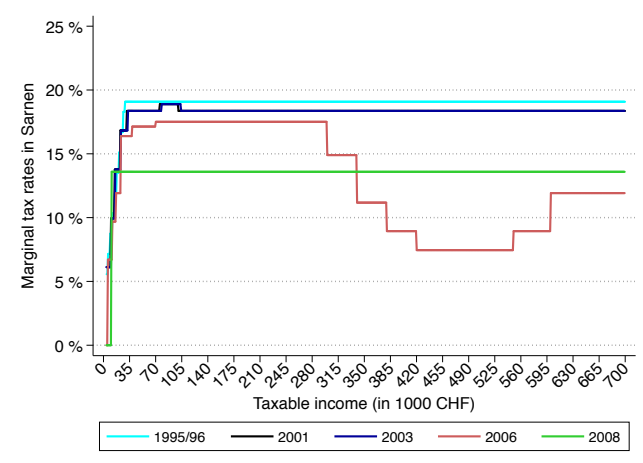

(a) Effective marginal tax rates

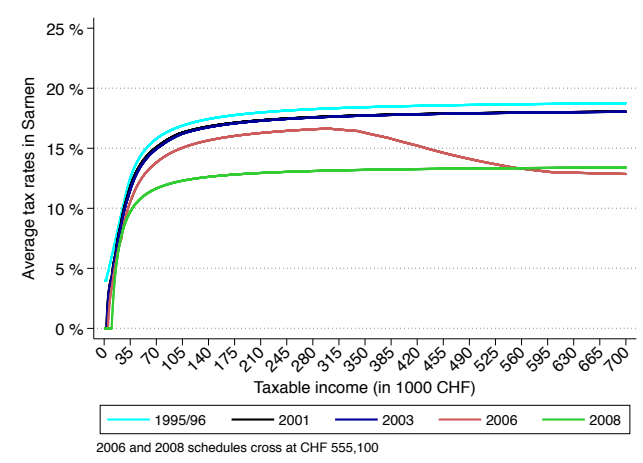

(b) Effective average tax rates

Figure 1: Effective average and marginal tax rates after different cantonal tax reforms

Note: Marginal and average tax rates for gross income of a single taxpayer, multiplied by the cantonal and the local tax multipliers. See Figure A3 in Appendix A for an overview of the marginal tax rates in all municipalities of the canton.

Source: Own calculations.

\section{Theoretical Model}

Cutting local taxes affects the income distribution and the potential for raising revenue through two channels. First, individuals may decide to move to the area if the average tax is lower than in their current place of residence. Second, residents affected by the tax cut may adjust their taxable income as a reaction of lower marginal tax rates. This implies two different elasticities with respect to taxation, a mobility elasticity and a reported income elasticity (also elasticity of taxable income ETI). In the following, both behavioral responses are presented in turn, and then they are combined to describe the overall effect the tax change has on the canton's tax base. 


\subsection{The Elasticity of Reported Income}

Tax Scheme. Assume there is a progressive, piece-wise linear tax scheme in place, with a marginal tax rate $\tau_{b}$ which is constant within each income bracket $b=1, \ldots, B$, but differs across brackets. Integrating the area under the tax curve $f(z)$ gives the amount of taxes due in a given canton $j, T_{j}(z)$. The average tax rate with respect to gross income $y$ is defined as: $\bar{\tau}=T_{j}(z) / y$.

Utility Maximization. In each period $t$, individuals $i$ living in canton $j$ maximize a utility function

$$
U_{j t}^{i}\left(c_{t}, z_{t}, \mu_{j t}^{i}\right)=c_{t}-h_{i}\left(z_{t}\right)+\mu_{j t}^{i},
$$

where $c_{t}$ is consumption in period $t, z_{t}$ is the individual's reported income, and $h_{i}\left(z_{t}\right)$ denotes the labor supply cost of earning $z$. This cost function $h_{i}\left(z_{t}\right)$ is increasing and convex, so that $h_{i}^{\prime}\left(z_{t}\right)>0$ and $h_{i}^{\prime \prime}(z)>0 . \mu_{j t}^{i}=\mu_{1 t}^{i}, \ldots, \mu_{J t}^{i}$ are preference parameters individuals have for each canton, and there are $j=1, \ldots, J$ cantons to choose to move to, while keeping a given job and not moving out of the country. This is analogous to the location-choice framework in Kleven et al. (2013). ${ }^{10}$

The unobservable components $\mu_{j t}^{i}$ of this decision are assumed to increase the moving costs for the household. ${ }^{11}$

The budget constraint takes on the form

$$
c_{t}=z_{t}-T_{j}\left(z_{t}\right)=z_{t}\left(1-\tau_{j t}\right)+R_{j t},
$$

where $R_{j t}=\left(z_{t} \tau_{j t}-T_{j}\left(z_{t}\right)\right)$ denotes virtual income from the non-linear tax schedule, arising from the fact that incomes below the tax bracket the individual is in are taxed at a different (usually lower) rate (for an illustration of the virtual income concept, see Gruber and Saez, 2002; Saez, 2013).

The Elasticity of Reported Income. Abstracting from income effects, the resulting "reported income supply function" reads as $z_{i t}\left(1-\tau_{j t}\right) .{ }^{12}$ This is the crucial function to

\footnotetext{
${ }^{10}$ An alternative interpretation of $\mu_{j t}^{i}$ would be that of the stochastic part in a random utility model (RUM) where individuals decide about moving, nested in the utility function (1).

${ }^{11}$ If $\mu_{j t}^{i}$ was zero so that the moving decision would be fully explained by the tax difference and the distance to the new location, this would imply unrealistically high tax-induced mobility. There are only very few unobserved factors presumably reducing mobility costs, e.g., the location of the workplace and duration of the commute. If however, commuting is not expensive, and given that commuting expenses can be deducted from taxable income, commuting reduces taxable income ceteris paribus.

${ }^{12}$ With the exception of Gruber and Saez (2002), the ETI literature usually abstracts from income effects, which considerably simplifies the presentation especially of efficiency effects. The reason is that empirical estimates suggest that income effects are small, especially in the case of reported income (see for example the estimates in Kleven and Schultz, 2014). Note that $R$ is only a virtual income component arising from the tax scheme and therefore entering the individual's budget constraint, but it is not part of taxable income. For a discussion of the relevance of income effects in the estimation of the ETI the reader is referred to Gruber and Saez (2002) and (Saez et al., 2012, especially pp.5-6); for an overview on income effects in labor supply models see Blundell and MaCurdy (1999).
} 
determine the elasticity of reported income with respect to the net-of-tax rate, defined as

$$
e=\frac{1-\tau_{j t}}{z_{i t}} \cdot \frac{\partial z_{i t}}{\partial\left(1-\tau_{j t}\right)}
$$

\subsection{The Mobility Elasticity}

Migration Decision. From the reported income supply function, it is possible to determine the individually optimal reported income $z_{i t}^{\star}$ for each location $j$. $U_{j t}^{i}$ is the utility a tax unit $i$ would enjoy in canton $j$. The household chooses the canton that yields the highest utility, so that moving to $j$ is optimal if

$$
U_{j t}^{i}\left(z_{i}^{\star}\left(1-\tau_{j t}\right)\right)+\mu_{j t}^{i}>\max \left\{U_{j^{\prime} t}^{i}\left(z_{i t}^{\star}\left(1-\tau_{j^{\prime} t}\right)\right)+\mu_{j^{\prime} t}^{i}\right\}, \quad \forall j^{\prime} \neq j .
$$

While for the moving decision alone what matters is the average tax rate, this solution takes into account that individuals can not only choose a location, but adjust to the prevailing marginal tax rates.

The Mobility Elasticity. The presented utility framework corresponds to a random utility model (RUM), where utility is decomposed into a deterministic and an unobservable part: $U_{j t}^{i}(c, z)=V_{j t}^{i}(c, z)+\mu_{j t}^{i}$ (for a detailed overview of RUMs, see Train, 2009). Assuming that the individual and unobserved term $\mu_{j t}^{i}$ follows some extreme value distribution it is possible to determine the probability of moving, $P_{j t}^{i}$. The elasticity of moving with respect to the net of tax rate is then given by:

$$
\varepsilon_{j t}^{i}=\frac{\mathrm{d} \log P_{j t}^{i}}{\mathrm{~d} \log \left(1-\tau_{j t}\right)} .
$$

Location choice models, however, become increasingly complex when the choice set is large. In the present context, individuals theoretically have more than 2000 municipalities to choose from when deciding where to relocate. Furthermore, this approach would require to compute households' hypothetical tax load in each Swiss municipality in every year. Unfortunately, there is no tool comparable to the tax calculator TAXSIM by Feenberg and Coutts (1993), which allows computing marginal and average tax rates for all U.S. states, in the Swiss context. Instead, I rely on a combined 2SLS and DiD approach to estimate the mobility elasticity in Section 7.

\subsection{The Total Elasticity of the Canton's Tax Base}

What has been presented so far, were the individual income elasticities and moving probabilities. Here I show how the two behavioral responses add up to the total elasticity of a canton's tax base into a part of real responses to taxation, e.g., labor supply responses, 
and into a part of moving responses. Together, these elasticities determine how much a canton can increase its tax base by cutting taxes.

Rather than an individual's taxable income, let now $z_{b t}$ be a canton's tax base, i.e., the sum of reported incomes in year $t$ and tax bracket $b . x_{t}$ denotes the sum of incomes in that bracket $b$ that moved to the canton (potentially from a higher-tax canton) during period $t$, such that $z_{t}=z_{t-1}+\Delta z_{t-1}+x_{t}$. The term $\Delta z_{t-1}$ accounts for changes in residents' taxable income and for losses in taxable income due to taxpayers moving out or dying.

Now assume there is one canton, $l$, which lowers its income tax by introducing a regressive schedule. Taking all other cantons' taxes as given, there will be a fraction of taxpayers residing in the surrounding cantons for whom $\tau_{j t}>\tau_{l t}$. They may consider moving to canton $l$ and take their taxable income with them.

Individuals maximize utility along the lines set out above. Aggregating over all taxpayers in a given income bracket $b$ after moving decisions and adjustments in taxable income have been made, one obtains the overall elasticity of reported income in canton $l$ :

$$
e=\frac{1-\tau_{l t}}{z_{t}} \cdot \frac{d z_{t}}{d\left(1-\tau_{l t}\right)}
$$

This elasticity can be thought of as consisting of two components: the elasticity $e_{1}$ of reported income of former residents of canton $l$, and the elasticity of attractable income, $e_{2}$. The former residents of canton $l$ have an elasticity of reported income of

$$
e_{1}=\frac{\left(1-\tau_{l t}\right)}{z_{t-1}} \frac{d z_{t-1}}{d\left(1-\tau_{l t}\right)} .
$$

The part of taxable income attracted from other cantons due to the tax cut, $x_{t}=$ $x_{t}\left(\tau_{j t}-\tau_{l t}\right)$, is increasing in the tax rate difference $\tau_{j t}-\tau_{l t} . x(0)=0$ as there is no reason to move away for tax reasons if tax rates are identical. Hence, $z_{l t}=z_{l t}\left(1-\tau_{l t}, \tau_{j t}\right)=$ $z_{l, t-1}\left(1-\tau_{l t}\right)-x\left(\tau_{j t}-\tau_{l t}\right)$ is increasing in the net-of-tax rate $\left(1-\tau_{l t}\right)$ and the other cantons' marginal tax rates $\tau_{j t}$.

Following the lines of Piketty et al. (2014), the moving elasticity of the tax base with respect to taxation can be defined as $e_{2}=s \cdot e . s$ denotes the fraction of the behavioral response of $z_{t}$ to $\mathrm{d} \tau_{l t}$ due to individuals moving to the low-tax canton $l$ for tax reasons.

$$
s=\frac{d x / d\left(\tau_{j t}-\tau_{l t}\right)}{d z_{t} / d\left(1-\tau_{l t}\right)+d x / d\left(\tau_{j t}-\tau_{l t}\right)}=\frac{d x / d\left(\tau_{j t}-\tau_{l t}\right)}{\partial z_{t} / \partial\left(1-\tau_{l t}\right)},
$$

and

$$
e_{2}=s \cdot e=\frac{1-\tau_{l t}}{z_{t}} \frac{d x}{d\left(\tau_{j t}-\tau_{l t}\right)}
$$


By construction $(1-s) e=\left(z_{t-1} / z_{t}\right) e_{1}$ or $e=\left(z_{t-1} / z_{t}\right) e_{1}+e_{2}$. Starting from a situation with no gains in the tax base due to tax-induced in-migration, $z_{t}=z_{t-1}$, the total elasticity is the sum of the standard labor supply elasticity and the tax-induced inmigration elasticity: $e=e_{1}+e_{2}$.

\section{Data}

\subsection{Federal Income Tax Data}

The first approach to assess the effect of the reform is based on a cross-cantonal comparison of the share of rich taxpayers and their incomes using federal income tax data. The federal income tax data have the advantage that they allow comparing incomes across cantons and over time, since the definition of taxable income is identical across cantons and has remained remarkably stable over time. Furthermore, the individual data are available for the period 1971-2012, allowing to control for pre-reform trends. Due to minor changes in the data structure and quality prior to the tax period 1989, I use the years 1989-2010 for the analysis. Prior to 2001, Switzerland had a biennial praenumerando tax system, such that only income data for every second year is available. The praenumerando system also implies that incomes were realized in the period preceding the tax period: in tax period 1989/90 incomes realized in 1987/88 are reported and averaged over two years. ${ }^{13}$

While the federal tax data is encompassing in time and space, it is limited in scope. The only income variables are taxable and so-called net income ("Revenu net" or "Reineinkommen"), both encompassing all taxable income sources from labor and capital. Net income is net of itemized deductions but not net of social deductions nor taxes. Realized capital gains remain untaxed at the individual level in Switzerland and are therefore not part of the income definition. Wealth is taxed at the cantonal and municipal level only, which is why the federal tax statistics do not contain information on wealth. Available individual characteristics are marital status, number of children, employment status (employee, selfemployed, non-working), and municipality of residence. Because individual identifiers are set at the cantonal level, it is not possible to follow individuals over time once they leave their canton of residence. Note, finally, that married couples have to file together and a taxpayer may therefore be an individual or a married couple (cohabiting individuals always file separately).

Due to some of these limitations, the first approach to assess the effect of the reform in

\footnotetext{
${ }^{13}$ For details on the praenumrando tax system and the change to the postnumerando system in the late 1990s, see Föllmi and Martínez (2014).
} 


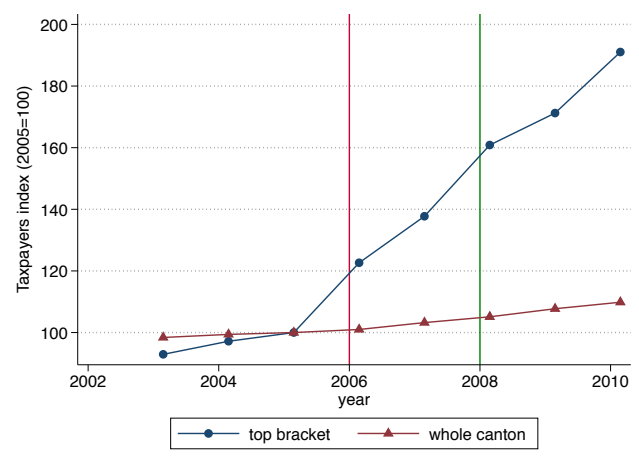

(a) Evolution of taxpayers

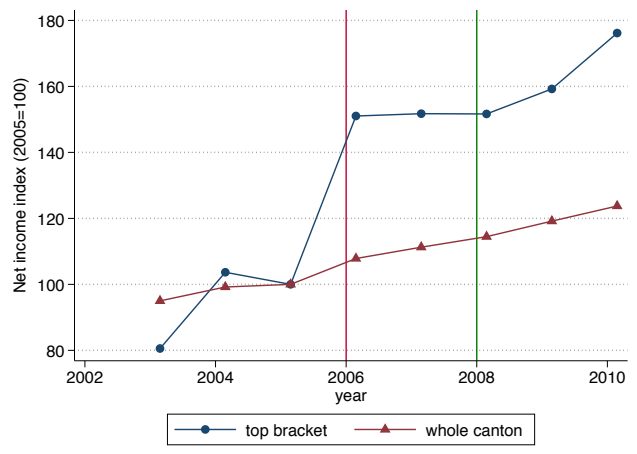

(b) Income evolution

Figure 2: Evolution of net income and taxpayers in Obwalden, top bracket and overall

Note: Net income as defined by the federal income tax ("Revenu net" or "Reineinkommen"), this is: income net of itemized deductions, but not net of social deductions and taxes. Top bracket: net income $>200,000 \mathrm{CHF}$. Source: Federal income tax statistics, 2003-2010, ESTV.

Obwalden (Section 6) is based on data aggregated at the municipality level. In Section 7 I overcome some of these limitations by using cantonal income tax data from Obwalden, which is very rich in detail but limited to Obwalden.

\subsubsection{Descriptive statistics}

Descriptive inspection of the number of taxpayers and the income arising from the top bracket of the federal income tax statistics (200,000 CHF and more) suggests that Obwalden indeed experienced a large increase in rich taxpayers after 2005. Figure 2 shows indices for taxpayers (Panel a) and net income (Panel b) in the top bracket and the whole canton $(2005=100)$. Obwalden has experienced a steady increase in tax units, but this has been much steeper in the top bracket than overall: from 2005 to 2006, the share of taxpayers in the latter group increased by $20 \%$. (Figure 2.a). While the increase in taxpayers has been steady, the increase of net income in the top bracket is characterized by an increase of $50 \%$ from 2005 to 2006 (Figure 2.b). This suggests that top incomes have increased remarkably, especially since there are only some 200 to 250 taxpayers (in 2005 and 2006, respectively) in this bracket in the federal statistics.

Comparing these experiences to neighboring and near-by cantons shows that the lowtax neighbors Schwyz and Zug experienced only a slight increase in their tax base at the top after 2006. In Nidwalden, a third low-tax canton, there was no increase in the top bracket at all. The sharp jump observed in Obwalden in 2006 is therefore a really unique phenomenon.

These developments across cantons are a first indicator that the observed increase 
in rich taxpayers and their incomes is unlikely due to spurious correlation, caused for example by a positive income shock in 2006 affecting the top $1 \%$ in the whole country but not the bottom 99\%. This suggest that the growing share of rich taxpayers in Obwalden's population may indeed have been triggered by the large tax cut for top incomes. 


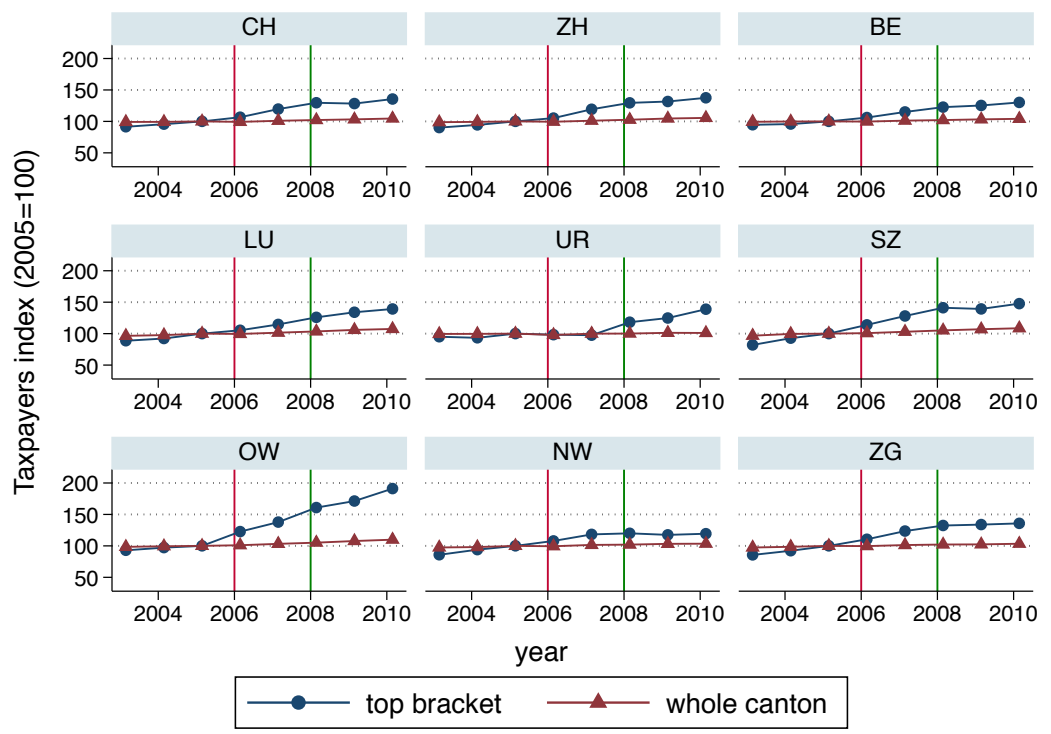

(a) Evolution of taxpayers

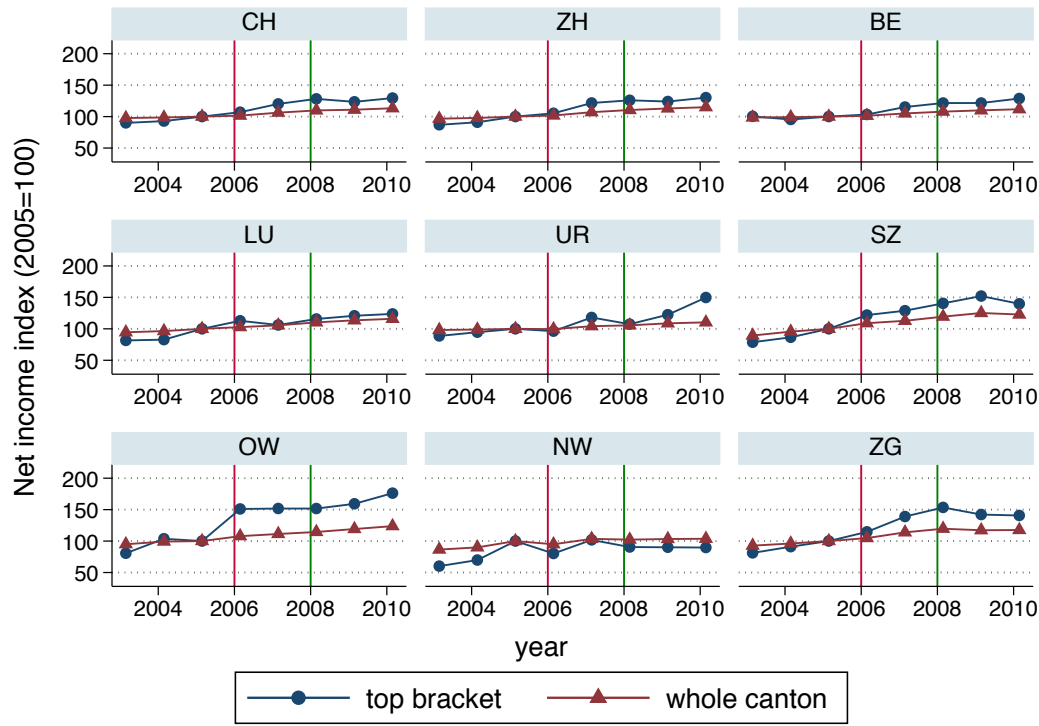

(b) Income evolution

Figure 3: Evolution of taxpayers and net income in selected cantons, top bracket and overall

Note: Net income as defined by the federal income tax ("Revenu net" or "Reineinkommen"), this is: income net of itemized deductions, but not net of social deductions and taxes. Top bracket: net income $>200,000$ CHF. Source: Federal income tax statistics, 2003-2010, ESTV. 


\subsection{Cantonal Income and Wealth Tax Data from Obwalden}

To overcome some of the limitations of the federal income tax data, I use individual income tax data from the Canton of Obwalden for the period 2001 to $2010 .{ }^{14}$ These register data are of very high quality and detail. The panel data contain the full information collected in the annual income tax returns such as all sources of income and all deductions applied as well as some basic information about the tax unit like age, nationality, marital status, number of dependents, and self-declared occupation. What makes the data unique is that in addition, the records contain the exact date when a taxpayer registered with the municipality, along with their canton and municipality of origin, or the country of origin if they moved-in from abroad. This allows to shed light on the moving behavior of taxpayers.

However, the data are limited to taxpayers with a tax liability in the canton of Obwalden during the period 2001 to 2010. Because individuals have a cantonal rather than a national tax id, it is not possible to link individual tax data from different cantons. I therefore lack information on wealth and incomes earned before moving to Obwalden or after leaving the canton. Similarly, it is not possible to identify the intentionally treated non-movers from other cantons.

Obwalden being a small canton, the number of observations is relatively small compared to similar studies. The total population is roughly 35,000 individuals in 2010 ( $0.5 \%$ of the Swiss population), which corresponds to 18,000 to 22,000 taxpayers each year (since married couples file together). This small population size has its drawbacks when it comes to the analysis, but it has to be noted that all the cantons engaging successfully in tax competition by lowering their rates are small in terms of population and geographical area. This is not surprising, since a small, open economy has relatively large potential gains from cutting taxes as the tax base increases, but relatively small losses in foregone revenue. This is in line with the small size of tax havens for off-shore wealth (for theory and evidence on asymmetric tax competition where countries differ in size, see Wilson, 1991,9; Winner, 2005; Habermacher and Kirchgässner, 2012), and Obwalden can be seen as representative in the case of competing over income taxes. Its proximity to the cities of Lucerne and Zurich harbors potential to attract high-income and wealthy taxpayers seeking a favorable place of residence with respect to taxes as well as centrality and natural amenities.

\footnotetext{
${ }^{14}$ These data have been kindly provided by the Tax Administration of the Canton of Obwalden for this research project.
} 


\subsubsection{Descriptive statistics}

The data allow for a descriptive analysis of the characteristics of the new arriving taxpayers in the canton (the in-comers or in-movers) before and after the reform. Figure 4 depicts average taxable income and wealth of in-comers (left scale) along with their number each year (right scale). Over the decade under consideration, the number of in-comers has been increasing, starting already before the 2006 tax cut on high incomes. Looking at in-comers' average taxable income and wealth, however, suggests that there has been a change in the type of in-comers right after the tax cut: both income and wealth of in-comers increased sharply right after the tax cut. In the years after, this increase was reverted somewhat but average income and wealth of in-movers stayed above pre-reform levels. This is noteworthy, since there was a sharp economic downturn in 2008/2009 and one might have expected a drop in average income and wealth of in-comers. Median income and wealth (Panels c) and d) of Figure 4) follow similar patterns as the average, suggesting that the results are not driven by extreme outliers. 


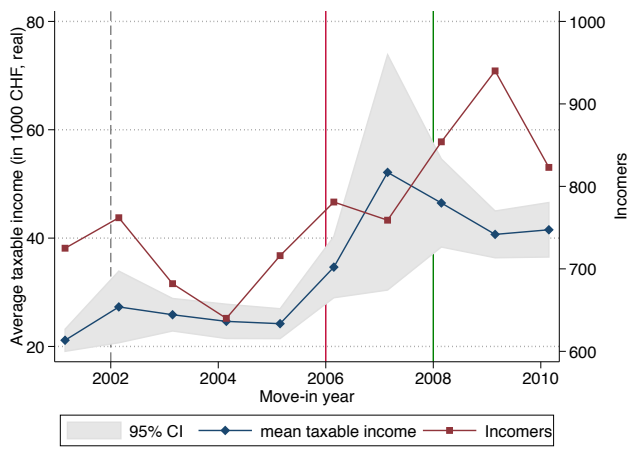

(a) Average income

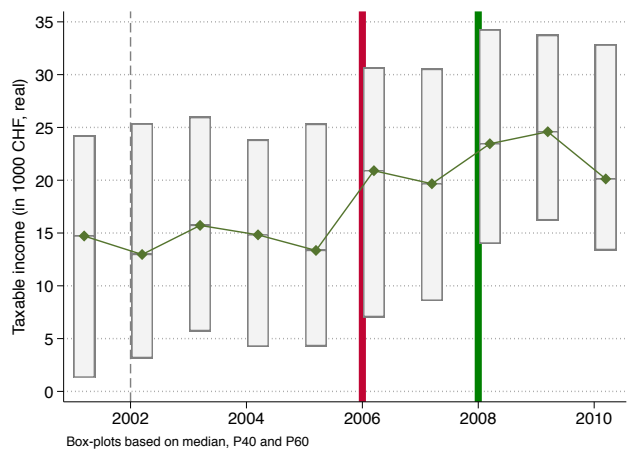

(c) Median income

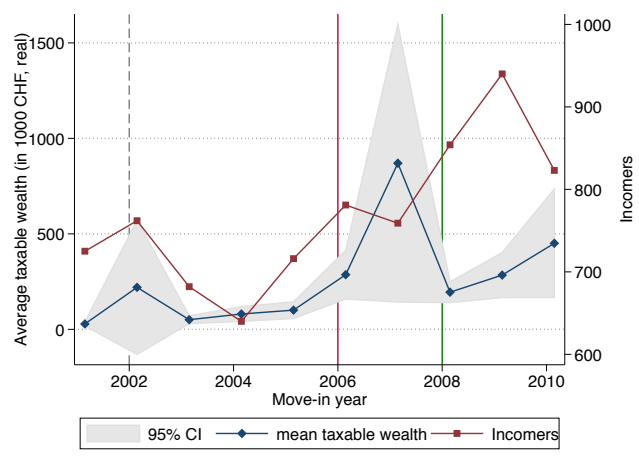

(b) Average wealth

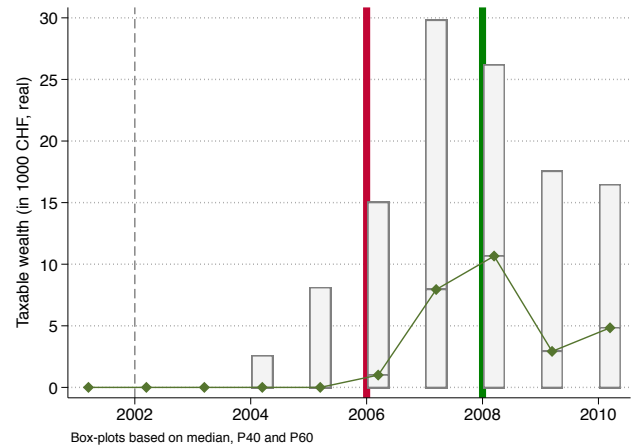

(d) Median wealth

Figure 4: In-comers and their average and median taxable income and wealth in move-in year

Note: Taxpayers moving to Obwalden in year $t$ pay taxes in Obwalden in that year. The red line 2006 marks the introduction of the regressive schedule, in 2008 (green line) the flat rate tax came into place; the grey dotted line marks the introduction of the AFMP with the EU.

Source: Personal income and wealth tax data Obwalden, 2001-2010.

The observed increase in average taxable incomes of newly arriving taxpayers has been due to increases in both, mobile income sources, such as dividends or real-estate income, and immobile income sources, such as labor income (Figure 5). The strong increase in average mobile income per in-mover is not very surprising. Taxpayers relying on incomes whose realization is independent of the canton of residence can be expected to be more mobile and therefore more responsive to changes in taxation. However, also the average labor incomes of in-movers were higher right after the cut. Although information on the location of the workplace is not available, assuming that the tax-cut did not create a substantial number of new, high-paying jobs taken by in-comers rather than residents, this suggests that the canton of Obwalden has the potential to attract not only mobile capital income, but also more immobile labor incomes. As Figure 6 shows, indeed many in-comers moved in from geographically close cantons, allowing to commute to the same 
job.

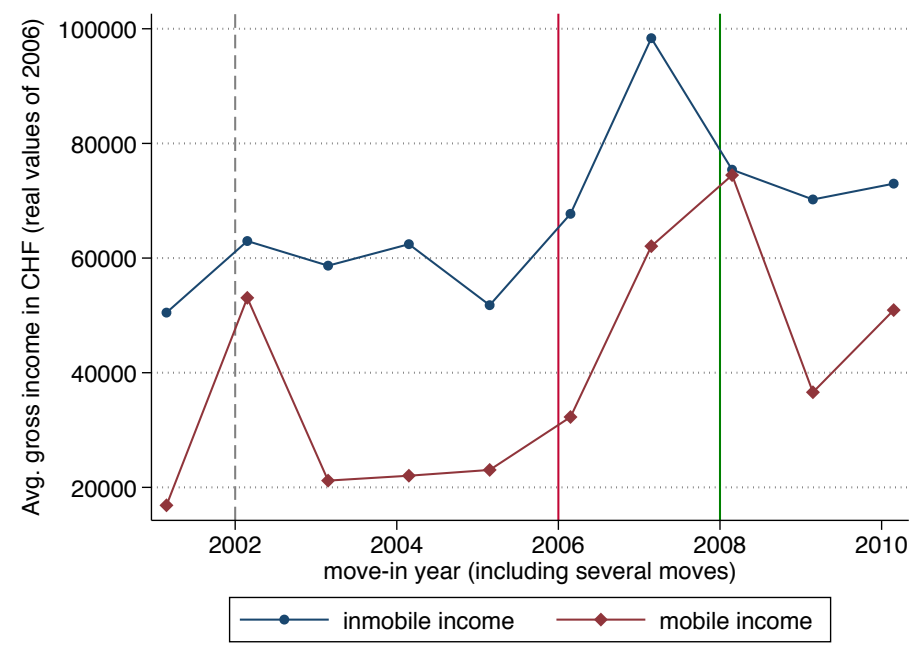

Figure 5: In-comers' average gross mobile and immobile income, 2001-2010

Note: All location-independent income sources are defined as mobile income, including all kinds of capital incomes such as interest income on bank accounts, dividends, returns on shares etc., as well as transfer incomes, such as unemployment benefits, alimony payments from ex-spouses etc. Labor income from employment and self-employment is classified as immobile income. Gross values before deductions.

The red line 2006 marks the introduction of the regressive schedule, in 2008 (green line) the flat rate tax came into place; the grey dotted line marks the introduction of the AFMP with the EU.

Source: Personal income and wealth tax data Obwalden, 2001-2010.

Considering the origin of taxpayers, the majority of in-comers moved-in from Lucerne and Nidwalden, the two major neighboring cantons, followed by large cantons like Zurich, Aargau and Bern as well as from abroad (Figure 6). Figure 6 further shows the origin of taxpayers with incomes larger than 300,000 CHF in at least one year of the period 2001-2010 (red bars). Again, most of them moved from Lucerne, followed by Zurich, Nidwalden, and Solothurn. 


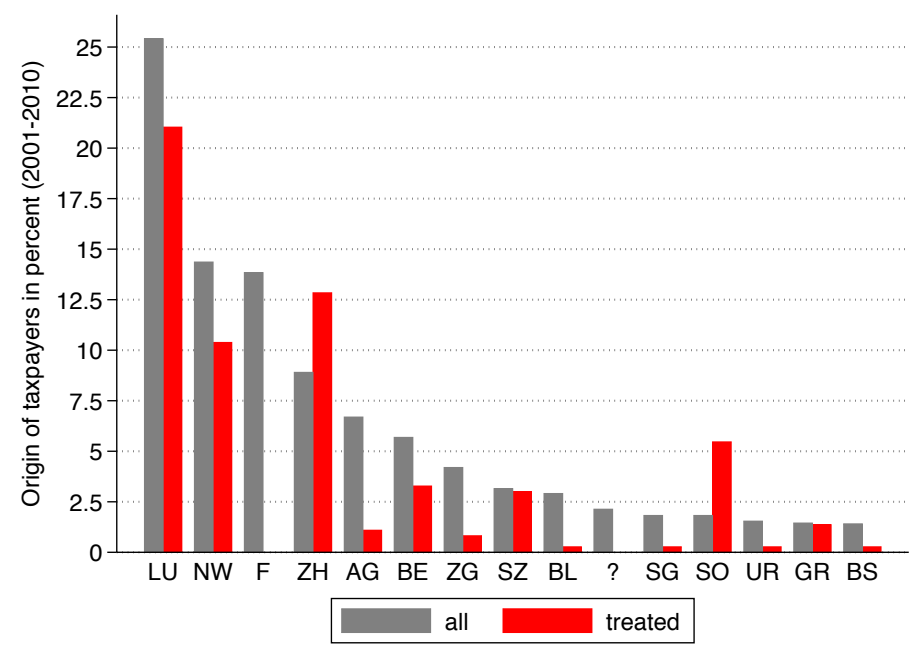

Figure 6: Origin of taxpayers who moved to Obwalden in the period 2001-2010

Note: The graph shows the origin of taxpayers in percent of all in-comers (grey bars) and in percent of the treated in-comers with rate-determining income above the regressive threshold of 300,000 CHF (red bars). F stands for foreign, i.e., taxpayers who moved-in from abroad. ? indicates cases where the origin is not reported in the data. Source: Personal income and wealth tax data Obwalden, 2001-2010.

\section{Comparison with the Neighbors Nidwalden and Lucerne}

The fiscally federal setting of Switzerland bears one important advantage when studying the effect of tax reforms compared to more unitary systems. Since the reform directly affected taxpayers living in Obwalden only, but not those living in other cantons, there are potentially 25 control groups Obwalden can be compared to.

\subsection{DiD Estimates of Relative Performance}

Unfortunately, the available individual federal income tax data is not detailed enough and has no unique tax-id to identify taxpayers across time and cantons. This impedes a comparison of individuals across cantons. I therefore estimate how the reform affected aggregate outcomes in Obwalden compared to its neighbors in a DiD setting. Using the federal income tax data described in Section 5, I compare (i) the share of rich, defined as taxpayers with federal taxable income above 300,000 CHF, in percent of the total of taxpayers, and (ii) net income per taxpayer. Making use of yet another data source, the cantonal revenue statistics and balance sheets, I finally analyze (iii) the effect on cantonal tax revenue. The first outcome is a direct measure of whether the reform was successful in attracting and retaining rich taxpayers. The second sheds light on how the reform affected the tax base on average. The third outcome addresses the question whether 
Obwalden was on the wrong side of the Laffer curve before the reform, such that the tax cuts led to an increase in tax revenue.

In case of the first two outcomes, rather than comparing Obwalden to all other 25 cantons, I make the comparison with its two direct neighbors, Lucerne (LU) and Nidwalden (NW). Nidwalden is a suitable control group since it's geographic characteristics, size and location are very similar to that of Obwalden, making commuting times to all major cities in the area, namely Lucerne, Zurich (ZH), and Zug (ZG), comparable. The canton Lucerne is Obwalden's major neighbor and hosts the closest urban center, the city of Lucerne. Obwalden, Nidwalden and Lucerne all share the same local labor market. In addition, both comparison cantons fulfill the parallel trends assumption in the outcomes under consideration needed for the DiD estimation (see Figures 7 and 8).

A major difference between the cantons is the average tax burden at different income levels. Nidwalden has always had lower taxes than Obwalden, while in Lucerne, especially the city, taxes were always higher. Nidwalden was one of the cantons Obwalden wanted to challenge by meeting or even undercutting Nidwalden's tax rates for high income and wealth levels. This can be seen in Figure B3 in the Appendix, which shows the evolution of tax rates in the two cantons for different gross income levels for comparison. It is apparent that the reform aimed at undercutting the traditional low-tax canton at high incomes only. Even after the flat rate tax introduction in 2008, the average tax rate is higher in Obwalden for Married taxpayers without children with a modest gross income of 60,000 CHF. Figure B4 compares the corresponding evolution of tax rates in Lucerne and Obwalden. In these two cantons tax rates have moved fairly parallel. In fact, Lucerne adopted major tax cuts in 2008 and 2010, hoping to attract rich taxpayers as well. Summing up, the 2006 reform in Obwalden reduced tax rates for everyone, but the tax cuts were by far largest for high incomes.

In the DiD estimations presented below, the unit of analysis are the municipalities within each canton. This results in seven treated municipalities in Obwalden, eleven control municipalities in Nidwalden, and 83 control municipalities in Lucerne. For both outcomes of interest - the share of rich and the average income per taxpayer - the reduced form estimates are based on the following specification of a simple DiD model:

$$
Y_{g, c, t}=\alpha+\beta \cdot(T R \cdot P R)+\lambda \cdot T R+\gamma \cdot P R+\epsilon_{g, c, t} \quad,
$$

where $Y_{g, i, t}$ denotes the outcome at time $t$ in a municipality $g$ belonging to canton $c=$ $\{0,1\}$, indicating whether the municipality lies in the treated canton Obwalden or in the comparison canton. $T R=\mathbb{1}[i=1]$ is the treatment group dummy, $P R=\mathbb{1}[t \geq 2006]$ 
is a dummy indicating the post-reform period. The coefficient of interest $\beta$ is the $\mathrm{DiD}$ estimator measuring the effect of the reform on the outcome. This baseline specification is then extended to include time trends and fixed effects.

\subsubsection{Outcome 1: Share of rich taxpayers}

Figure 7 depicts the share of taxpayers in Lucerne, Nidwalden, and Obwalden, respectively, with taxable income above $300,000 \mathrm{CHF} .{ }^{15}$ For illustrative purposes, the series are scaled such that Obwalden matches the comparison canton in 2005. ${ }^{16}$ Both Panels a) and b) show how the share of rich taxpayers increased steeply after the reform in Obwalden. Especially in comparison with Lucerne, the increase has been dramatic.

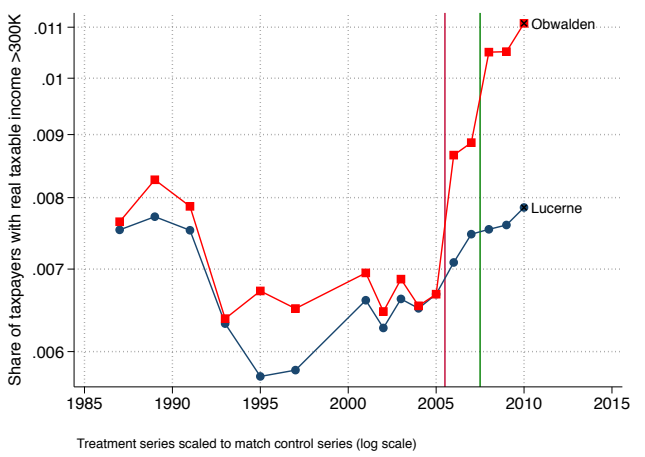

(a) Lucerne vs. Obwalden

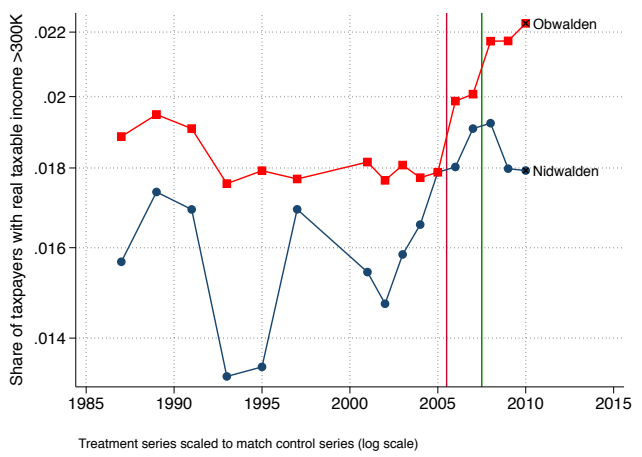

(b) Nidwalden vs. Obwalden

Figure 7: Share of rich taxpayers with federal taxable income $>300,000 \mathrm{CHF}$

Note: Treatment series scaled to match control series in 2005 (log scale).

Source: Individual federal income tax data, ESTV Bern

Table 1 shows the DiD estimates of the log share in rich taxpayers with taxable income above 300,000 CHF, estimated separately for each comparison canton according to equation (9) and extensions thereof. Top Panel A presents results for the comparison with Lucerne, estimates in Panel B at the bottom of the table stem from the comparison with Nidwalden.

The estimated baseline increase in the share of rich taxpayers in Obwalden due to the tax reform is $\exp (0.215)=24 \%$ when compared to Lucerne, and $30 \%$ when compared to Nidwalden. These estimates are robust to the inclusion of year and municipality fixed effects (Columns 3 and 4, respectively), although in the case of Nidwalden, they become statistically insignificant. Adding a time trend (Column 2) rises the estimates above $35 \%$

\footnotetext{
${ }^{15}$ This is federal taxable income, which generally exceeds cantonal taxable income as deductions at the federal level are less generous than at the cantonal level.

${ }^{16}$ In reality, Obwalden's share of rich taxpayers before the tax reform was lower than in Nidwalden and Lucerne.
} 
in both comparison scenarios. Overall, coefficients are comparable when estimated with either Nidwalden or Lucerne as a control group. Given that the comparison with Lucerne satisfies the parallel trends assumption in a more satisfactory way than with Nidwalden, the somewhat smaller estimates from the comparison with Lucerne are, however, more trustworthy and precise.

Table 1: DiD estimates of log share of rich in the canton

\begin{tabular}{|c|c|c|c|c|}
\hline & $\begin{array}{c}(1) \\
\text { Baseline }\end{array}$ & $\begin{array}{c}(2) \\
\text { Canton } \\
\text { trend }\end{array}$ & $\begin{array}{l}(3) \\
\text { Year } \\
\text { FE }\end{array}$ & $\begin{array}{c}(4) \\
\text { Municipality } \\
\text { FE }\end{array}$ \\
\hline & \multicolumn{4}{|c|}{ Panel A: Lucerne } \\
\hline DiD & $\begin{array}{c}0.215^{*} \\
(0.109)\end{array}$ & $\begin{array}{c}0.302^{* * *} \\
(0.0801)\end{array}$ & $\begin{array}{c}0.217^{*} \\
(0.109)\end{array}$ & $\begin{array}{c}0.230^{* *} \\
(0.109)\end{array}$ \\
\hline Canton-specific trend & No & Yes & No & No \\
\hline Year FE & No & No & Yes & Yes \\
\hline Municipality FE & No & No & No & Yes \\
\hline Observations & 1,411 & 1,411 & 1,411 & 1,411 \\
\hline R-squared & 0.012 & 0.013 & 0.022 & 0.084 \\
\hline \multirow[t]{2}{*}{ No. of clusters } & 110 & 110 & 110 & 110 \\
\hline & \multicolumn{4}{|c|}{ Panel B: Nidwalden } \\
\hline DiD & $\begin{array}{c}0.261^{*} \\
(0.148)\end{array}$ & $\begin{array}{l}0.310^{*} \\
(0.157)\end{array}$ & $\begin{array}{c}0.261 \\
(0.152)\end{array}$ & $\begin{array}{c}0.261 \\
(0.151)\end{array}$ \\
\hline Canton-specific trend & No & Yes & No & No \\
\hline Time FE & No & No & Yes & Yes \\
\hline Municipality FE & No & No & No & Yes \\
\hline Observations & 288 & 288 & 288 & 288 \\
\hline R-squared & 0.126 & 0.128 & 0.137 & 0.165 \\
\hline No. of clusters & 18 & 18 & 18 & 18 \\
\hline
\end{tabular}

$* * * \mathrm{p}<0.01,{ }^{* *} \mathrm{p}<0.05,{ }^{*} \mathrm{p}<0.1$

Note: In Models (1)-(3), standard errors are clustered at the municipality level, in Model (4) robust standard errors are reported. All regressions include a constant, a post-treatment dummy $(t>2005)$, and a treatment group dummy. DiD denotes the interaction of the post-treatment with the treatment group dummy, hence the Difference-in-Differences estimator.

Source: Individual federal income tax data, ESTV Bern. 


\subsubsection{Outcome 2: Net income per taxpayer}

The evolution of net income per taxpayer is plotted in Figure 8. Again pre-treatment trends are most similar for Obwalden and Lucerne. The dip in taxable income per taxpayer in the mid 1990s is mainly data driven. The number of taxpayers escalates from 1991 to 1993, thereby increasing the denominator. The reason for this is unclear, but is most probably related to changes in reporting tax statistics by the Federal Tax Administration. Therefore (and as can be seen from the graphs) it affects all cantons equally, such that it should not pose a threat to identification. While the increase in income per taxpayer after the reform in Obwalden is not as dramatic as the increase in the share of rich, it is still apparent how average income growth in Obwalden was steeper than in its neighboring cantons.

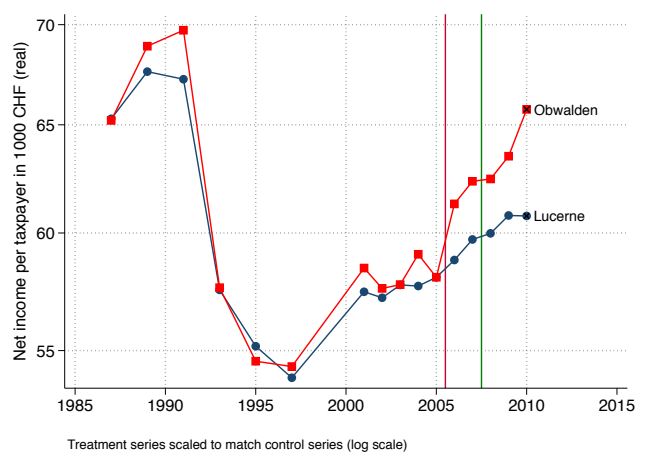

(a) Lucerne vs. Obwalden

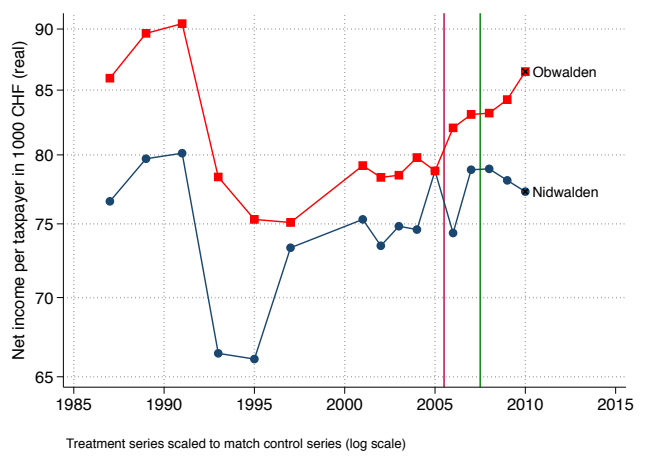

(b) Nidwalden vs. Obwalden

Figure 8: Net income per taxpayer

Note: Treatment series scaled to match control series in 2005 (log scale). Net income is "Reineinkommen" as defined by the federal income tax, i.e., net of itemized deductions but not net of social deductions nor taxes. Source: Individual federal income tax data, ESTV Bern.

The corresponding regression results are presented in Table 2. Column 1 presents the baseline reduced-form estimates. While the point estimate from the comparison with Lucerne (top Panel A) is small and statistically not significant at conventional levels, the estimate from the comparison with Nidwalden (bottom Panel B) suggests that in the five years after the 2006 reform, taxable income per taxpayer increased by roughly $17 \%$ more in Obwalden than it would in absence of the large tax cuts. Adding a canton-specific time trend (Column 2) suggests that compared with both cantons, average incomes in Obwalden rose by approximately $16 \%$. Controlling for municipality and time fixed effects, however, the effect vanishes completely (Column 3).

In Columns 4 and 5, finally, I split the sample into taxpayers with taxable incomes 
smaller than 300,000 CHF, and therefore falling below the regressive threshold, and into those with incomes above the threshold. As expected, the reform did not have an effect on average income of taxpayers below the threshold. For taxpayers above the threshold, however, net income per taxpayer rose significantly. The comparison with Lucerne suggests an increase in net income of rich taxpayers in Obwalden compared to the group of rich in Lucerne of almost 14\%. The estimates from the comparison with Nidwalden are even larger, suggesting a relative increase in average incomes of what should otherwise be comparable taxpayers of $26 \%$ in Obwalden.

The takeaway from these estimates is that the reform had a positive effect on net incomes per taxpayers, which concentrated among the rich. Stated differently, not only did the pool of rich taxpayers in Obwalden get larger, but also richer. This can be due to different factors, not only rich taxpayers moving to Obwalden, but also increases in (taxable) income by residents who now face a lower marginal tax rate, as well as residents who would have otherwise moved to a low-tax canton. That there is no effect among the "bottom 99\%" of taxpayers suggests that the reform did probably not trigger economic growth or job creation (which also was not the aim of the reform). 
Table 2: DiD regressions of net income per taxpayer

\begin{tabular}{|c|c|c|c|c|c|}
\hline & $\begin{array}{c}(1) \\
\text { Baseline }\end{array}$ & $\begin{array}{c}(2) \\
\text { Canton } \\
\text { trend }\end{array}$ & $\begin{array}{c}(3) \\
\text { Municip. } \\
\text { FE }\end{array}$ & $\begin{array}{c}(4) \\
\text { Sample: } \\
<300 K\end{array}$ & $\begin{array}{c}(5) \\
\text { Sample: } \\
>300 K\end{array}$ \\
\hline & \multicolumn{5}{|c|}{ Panel A: Lucerne } \\
\hline DiD & $\begin{array}{c}0.051 \\
(0.070)\end{array}$ & $\begin{array}{c}0.145^{* * *} \\
(0.055)\end{array}$ & $\begin{array}{c}0.036 \\
(0.057)\end{array}$ & $\begin{array}{l}-0.005 \\
(0.012)\end{array}$ & $\begin{array}{c}0.129^{*} \\
(0.067)\end{array}$ \\
\hline Canton-specific trend & No & Yes & No & No & No \\
\hline Time FE & No & No & Yes & Yes & Yes \\
\hline Municipality FE & No & No & Yes & Yes & Yes \\
\hline Controls & No & Yes & Yes & Yes & Yes \\
\hline Observations & 1,748 & 46,001 & 46,001 & 7,193 & 3,644 \\
\hline R-squared & 0.025 & 0.227 & 0.288 & 0.868 & 0.245 \\
\hline \multirow[t]{2}{*}{ No. of clusters } & 115 & 115 & 115 & 115 & 110 \\
\hline & \multicolumn{5}{|c|}{ Panel B: Nidwalden } \\
\hline DiD & $\begin{array}{l}0.156^{*} \\
(0.081)\end{array}$ & $\begin{array}{c}0.153^{* *} \\
(0.060)\end{array}$ & $\begin{array}{c}0.003 \\
(0.065)\end{array}$ & $\begin{array}{c}-0.008 \\
(0.014)\end{array}$ & $\begin{array}{c}0.234^{* *} \\
(0.088)\end{array}$ \\
\hline Canton-specific trend & No & Yes & No & No & No \\
\hline Time FE & No & No & Yes & Yes & Yes \\
\hline Municipality FE & No & No & Yes & Yes & Yes \\
\hline Controls & No & Yes & Yes & Yes & Yes \\
\hline Observations & 288 & 10,264 & 10,264 & 1,203 & 1,002 \\
\hline R-squared & 0.121 & 0.166 & 0.253 & 0.926 & 0.303 \\
\hline No. of clusters & 18 & 18 & 18 & 18 & 18 \\
\hline
\end{tabular}

$* * * \mathrm{p}<0.01, * * \mathrm{p}<0.05, * \mathrm{p}<0.1$

Note: Standard errors clustered at the municipality level. Observations are municipality-year cells. In Columns $2-5$ cells are further split into different binary characteristics of the taxpayers, namely: married, single parents, married with children (with single taxpayers with no dependents being the reference category), and self-employed, non-working, retiree (with employees being the reference category). By splitting up the municipality-year cells into these categories, the number of observations increases. Models (2)-(5) further control for cell size. Detailed results are reported in Tables B2 and B1 in the Appendix.

Source: Individual federal income tax data, ESTV Bern. 


\subsubsection{Outcome 3: Cantonal tax revenue}

To analyze the effect of the reform on cantonal tax revenue, I use he cantonal revenue statistics and balance sheets covering the period 1990-2014. ${ }^{17}$ In the same vein as in the approach laid out above, I compare tax revenue per capita ${ }^{18}$ from personal income taxes as well as total personal tax revenue from income and wealth taxes across cantons. Rather than limiting the analysis to comparisons with Lucerne and Nidwalden only, I here compare the revenue in Obwalden to that in each of the Swiss cantons in a simple DiD analysis of the 2006 tax reform as described in equation (9). A graphical inspection of the parallel trends assumption in tax revenues across cantons shows that for quite a few although not all cantons this assumption is fulfilled. Since in the four years prior to the reform trends are parallel to those in Obwalden in almost all 25 cantons, I run DiD regressions comparing all 25 cantons to Obwalden, using the time frame 2002-2014.

Figure 9 exemplary shows DiD estimates of the change in cantonal income tax revenue (Panel a) and in total personal income tax revenue (Panel b) due to the reform in Obwalden from a model controlling for canton-specific time trends. Both graphs show how in comparison with almost every canton, the point estimates indicate a negative effect of the reform. More then half of the estimates are statistically significantly smaller than zero. While this analysis is far from perfect, it indicates that in the best case the 2006 tax reform was revenue neutral. Despite the increase in the share of rich taxpayers after the reform, Obwalden was not on the wrong side of the famous Laffer curve.

\footnotetext{
${ }^{17}$ Finanzstatistik der Kantone, available online from the Federal Finance Administration: http://www.efv.admin.ch.

${ }^{18}$ Population data obtained from the Swiss Federal Statistical Office, BFS.
} 


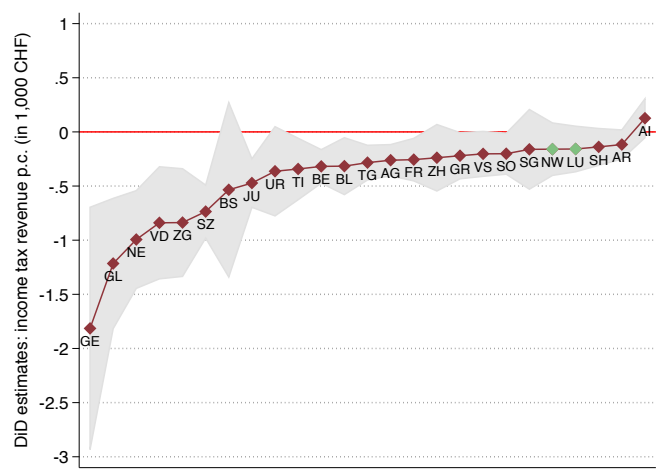

(a) Personal income tax revenue

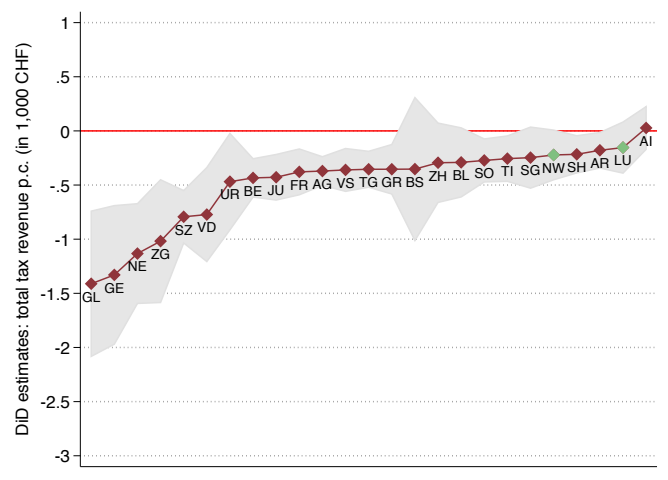

(b) Total personal tax revenue

Figure 9: DiD estimates of cantonal tax revenue in Obwalden and all other Swiss cantons

Note: Point estimates and 90\% confidence intervals from DiD regressions of personal income tax revenue (Panel a) and total personal tax revenue (Panel b) in pairwise comparisons of Obwalden with all other cantons. Data source: Finanzstatistik der Kantone, EFV.

\subsection{Robustness}

The presented results are relatively robust to variations in the model specification, such as the inclusion of linear time trends or municipality and time fixed effects. All the presented models are estimated in logs, and results tend to be statistically less significant when estimated in levels. Since the levels of the series differ quite substantially between Obwalden and the cantons used as controls, the specification in logs is more appropriate. Changes over time are made comparable despite the level differences. Additionally, the specification in logs allows for a straightforward interpretation of the results as percentage changes.

A potential threat to identification is movement into treatment. If taxpayers from Nidwalden and Lucerne moved to Obwalden in response to the treatment, this would inflate the reported estimates. I address this concern in the following subsection. In addition, I run a set of placebo estimations, placing the reform at different points in time in the pre-treatment period.

\subsubsection{Movement into treatment by cross-cantonal movers}

If rich taxpayers moved from Nidwalden and Lucerne, respectively, to Obwalden because of the treatment, these control groups were in fact negatively treated by the reform. In that case, the coefficients presented in Table 1 would be upward biased. Estimates would still be informative from a policy perspective in the Swiss context, but they would over-estimate the underlying responses of economic agents to tax changes. 
Combining the federal income tax data with the cantonal tax data from Obwalden, it is possible to correct the number of treated taxpayers in each of the control cantons and re-estimate the regressions on the share of rich taxpayers in each canton. Since the cantonal tax data from Obwalden reports the origin of taxpayers who moved there, I correct the number of rich in each canton by adding the number of treated taxpayers who moved to Obwalden after 2005 back to their municipality of origin, and subtracting them from their municipality of destination in Obwalden. For the very few cases where only the canton but not the municipality of origin is recorded, I still deduct the taxpayers from the municipalities in Obwalden. However, I am not able to assign them to a specific municipality in their canton of origin. This affects 5 observations in Nidwalden and 6 observations in Lucerne; in total, after 200511 treated taxpayers moved from Nidwalden and 27 from Lucerne to Obwalden. I calculate the corrected share of rich taxpayers in each canton and re-estimate the regressions of Table 1 . The obtained estimates should now represent a lower bound of the effect, because part of the response to the reform is shut down. This is especially true as Lucerne is one of the cantons from which the largest number of taxpayers comes from, both treated and untreated (see Figure 6).

Table B3 in the Appendix presents the estimates corrected for cross-cantonal movers. Interestingly, the estimated coefficients are larger than without the correction in both comparison groups and across most specifications. In the comparison with Lucerne, they all remain statistically significant. In the case of Nidwalden, the effect of the reform is not statistically significant anymore (Panel B). The point estimates still remain comparable between the two control scenarios and across different specifications. I conclude that the estimated increase in the share of rich taxpayers is therefore not driven by movement into treatment.

Net income per taxpayer, can unfortunately not be to corrected for cross-cantonal movers in a satisfactory way with the data at hand. Since I only observe moving patterns in the data from the canton of Obwalden, but not in the federal tax data used for these estimations, corrections taking into account both, origin and income, are not possible: because the data sets cannot be matched, it is not possible to correct for those incomes that are now reported in Obwalden, but were originally reported in Nidwalden or Lucerne.

\subsubsection{Placebo estimates}

The federal income tax data used here covers the period 1987-2010, therefore including an 18-year long pre-treatment period. This allows to conduct placebo tests of all the presented $\mathrm{DiD}$ estimates, by artificially specifying any year in the pre-treatment period 
as reform year. Under the hypothesis that the DiD estimates presented so far capture the true effect of the reform, the same estimates placing the reform in any year before 2006 (and excluding all periods after 2005 affected by the true reform), should be statistically insignificant. The results of these placebo tests are presented in the following graphs.

The placebo estimates for the log share of rich taxpayers in Obwalden compared to its neighbors are depicted in Figure 10. The estimates from the comparison with both neighbors show how prior to the actual reform Obwalden would have had a lower share of rich taxpayers. Note further that estimates for 2006 are corrected for cross-cantonal movers as described above. The graphs show that while in the case of Nidwalden (Panel b) the point estimate becomes statistically insignificant when correcting for movers, this is only marginally true. The difference between true reform estimate and the placebo estimates is substantial and stable over the whole pre-treatment period.

Similarly, the estimates of the change in real net income per taxpayer (Figure 11) are all close to zero or even negative in the comparison with Lucerne (Panel a) in the pre-treatment period. This confirms that the reform substantially increased income per taxpayer, presumably through inflows of taxpayers as well as adjustments in reported income. I find the same patterns from placebo estimates for a large range of different specifications, from baseline estimates to the inclusion of time trends an canton-specific time fixed effects.

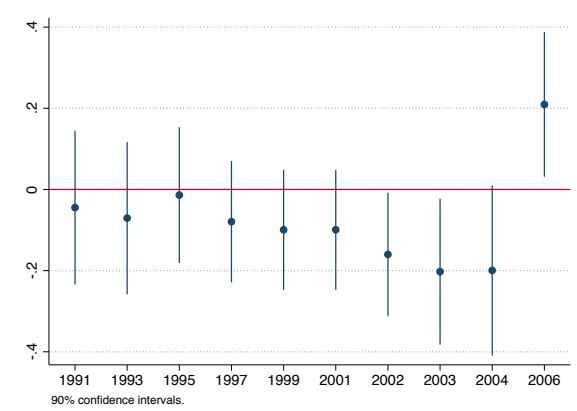

(a) Lucerne vs. Obwalden

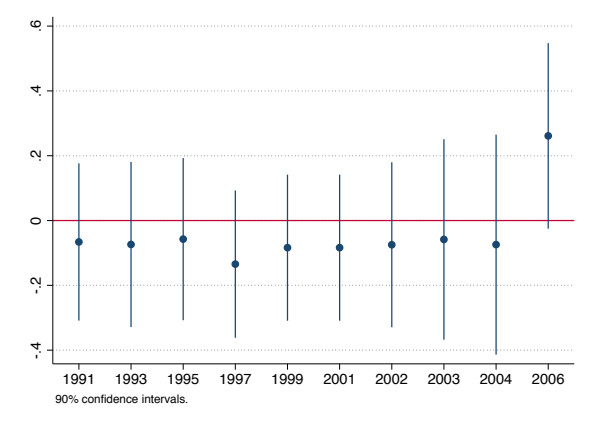

(b) Nidwalden vs. Obwalden

Figure 10: Placebo estimates for the log share of rich taxpayers

Note: The plots depict the DiD estimates of the log share of rich taxpayers in a municipality, corrected for cross-cantonal movers, including municipality and year fixed effects, analogous to Column 4 in Table B3. 


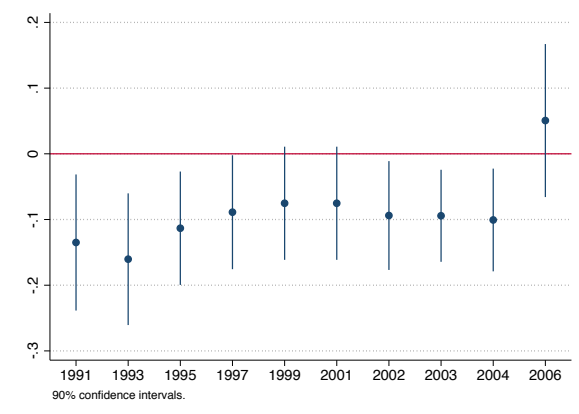

(a) Lucerne vs. Obwalden

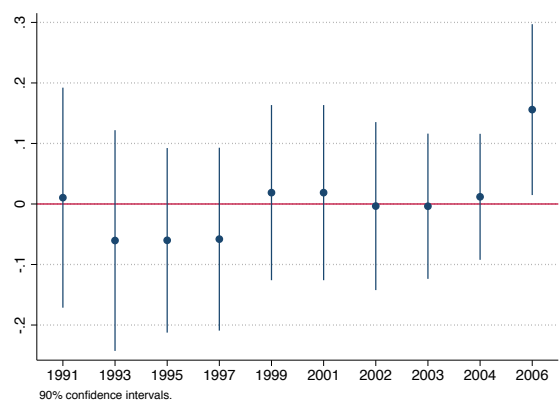

(b) Nidwalden vs. Obwalden

Figure 11: Placebo estimates for net income per taxpayer

Note: The plots depict the simple reduced form DiD estimates of the log net income per taxpayer in a municipality, analogous to Column 1 in Table 2.

\subsubsection{Capitalization into housing prices?}

One claim often made is that fiscal policy capitalizes in property prices, as suggested in the seminal paper of Oates (1969). Empirical studies find that capitalization of lower tax rates into property prices is imperfect in Switzerland (Kirchgässner and Pommerehne, 1996; Schmidheiny, 2006; Schaltegger et al., 2011). This is in line with the theoretical model by Stadelmann and Billon (2012), which predicts that full capitalization is only possible if the elasticity of supply in the housing market is zero. Given that the housing supply is elastic to some degree, moving to a low tax municipality pays off especially for rich households with high incomes, despite higher property prices. In a recent study based on Swiss data, Morger (2013) further shows that capitalization differs for different types of apartments and household groups, so that there is no "one true capitalization rate" (Morger, 2013, p.35). He finds that capitalization is moderate in most cases, except for low-quality apartments (demanded by low-income households) in nearby municipalities. This suggests that low tax rates may crowd out poor households through higher rental prices.

Housing data on condominiums, houses, and rental apartments in Obwalden and surrounding commuting zones and cantons, respectively, suggests that indeed prices for different housing types reacted differently to the reform. Figure 12 shows how after the reform prices for condominiums and houses increased only moderately, following common trends found in surrounding commuting zones. The price increase for condos was even below average compared to other regions. The same is not true for rental apartments. In this category, where prices are available only at cantonal level, prices increased substantially in 2006 and then again after 2008, when the flat rate tax was 
introduced.

Under the assumption that low-income households rely more heavily on rental apartments, these findings suggest that the reform could have affected low-income households negatively through housing prices. If high-income households on the other side have a preference for residential property, the evolution of real estate prices in Obwalden was moderate enough that these households would still benefit from low taxes.

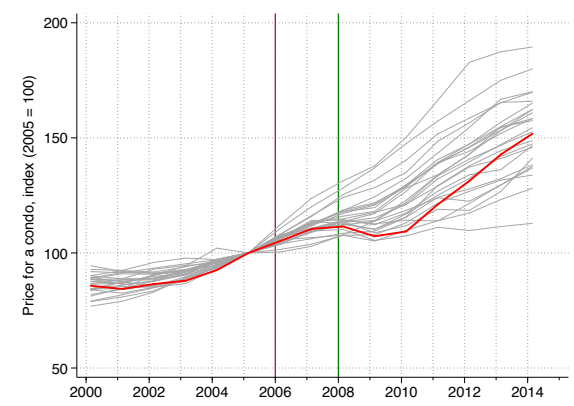

(a) Condominiums

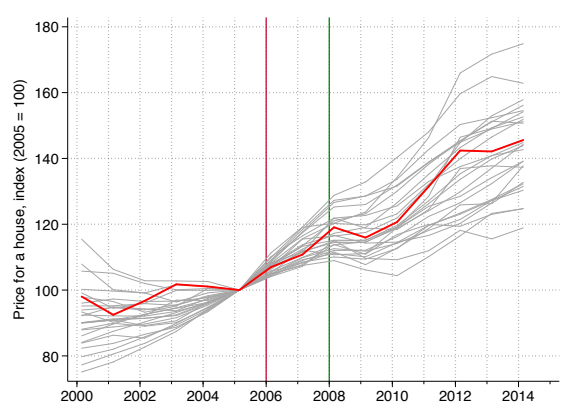

(b) Houses

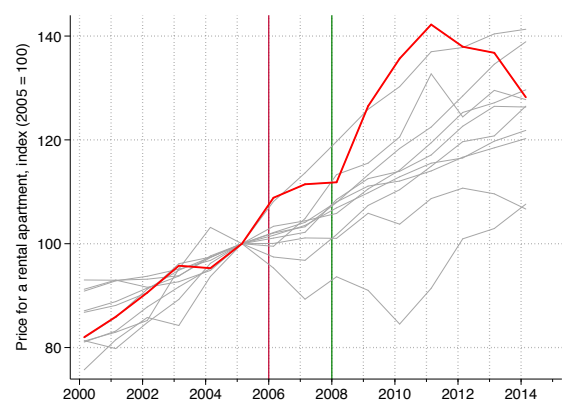

(c) Rental apartments

Figure 12: Price index for apartments, houses, and rentals in Obwalden and surrounding areas

Note: Panels a) and b) depict the hedonistic transaction price index for apartments and houses, respectively in 26 labor market regions. Panel c) shows the hedonistic offer price index for rental flats in 11 cantons.

Source: Wuest und Partner AG, Zurich.

\section{Individual Responses to the Regressive Income Tax Reform in Obwalden}

In this section, I first address how taxpayers responded to the tax reform and present estimates of the elasticity of rich tax payers in the canton with respect to the net-of-tax rate. These estimates are based on comparison of different income groups within in the canton, thereby following a method commonly used in the literature on responses to taxation. Subsection 7.2 presents estimates of the elasticity of taxable income (ETI) of 
top earners.

\subsection{Elasticity of Rich Taxpayers in the Canton using DiD Estimation}

Presumably, the 2006 tax reform lead to an increase in the stock of rich taxpayers above the regressive threshold, since they benefit from a falling marginal and average tax rate. The increase can be due to (i) an increased inflow of newly attracted taxpayers, (ii) prevented out-migration from high-income and wealthy taxpayers to other low tax cantons, and (iii) adjustments in (taxable) income of taxpayers already living in the canton. Using the detail-rich individual cantonal income tax data from Obwalden (described in Section $5.2)$ it is possible to shed light on the stock as well as on the inflow of rich taxpayers in the canton in response to the tax changes.

\subsubsection{Defining a suitable control group}

To estimate effects of the reform I define a control group not directly affected by the 2006 tax change and perform a set of DiD estimations. One possible control group are taxpayers with income (or wealth) just below the regressive scheme kicks in. This approach is similar to other studies in this field, including Kleven et al. (2013).

At this point, the important distinction between taxable and rate-determining income needs to be introduced. To avoid double taxation of incomes earned abroad, for example, but at the same time take into account the totality of income earned in a year to maintain the progressiveness of the tax scheme, the Swiss tax system uses two income definitions: taxable income and rate-determining income. Usually, taxable income determines the tax rate. Some taxpayers, especially top earners, however, have income from abroad or real-estate income from other cantons, which is taxed at the source in their corresponding jurisdictions. These incomes do not form part of taxable income in their place of residence, since they are not taxed twice. These incomes are, however, part of rate-determining income. Rate-determining income takes all income sources into account as if they were earned in the canton of residence, allowing for all applicable deductions (e.g., maintenance cost of real estate). This income is then used to determine the average tax rate of the taxpayer in the canton of residence. This average tax rate is then applied to the income which is taxable in the canton, the taxable income. Since it is rate-determining income which puts taxpayers either above or below the regressive part of the tax scheme, in what follows the treatment and control groups are defined according to their rate-determining income.

Figure 13 shows the evolution in the number of treated taxpayers compared to different 
control groups. Panels a) and b) depict the stock of all taxpayers living in a canton in a given year and falling into either the treatment or control category. The difference between Panel a) and Panel b) is that in the former the control group is defined as having a rate-determining income of $60-80 \%$ of the regressive threshold, while in Panel b) taxpayers with rate-determining income of up to $95 \%$ of the threshold, or 280,000 $\mathrm{CHF}$, are in the control group. While the latter group is closer to the treated, it seems as if the control group could be responding to the treatment, as their number goes up too after the tax reform. Especially in-comers from other cantons may have expected to have higher incomes in the future, or they their former canton of residence's income definition resulted in a higher taxable income than the taxable income they had according to Obwalden's tax laws.

As expected, both control groups seem to respond to the 2008 reform, while the number of originally treated taxpayers remains stable after 2007. This makes sense, since the 2008 reform implied large cuts in marginal and average tax rates for the control group, but only small changes for the originally treated.

Panels c) and d) of Figure 13 depict the flow of taxpayers moving to Obwalden in a given year. In Panel c) again the control group is defined as having rate-determining income of $60-80 \%$ of the regressive threshold. Again it seems that the control group responded to the treatment in 2006. Therefore, in Panel d) the control group is redefined as having a rate-determining income of $55-75 \%$ of the regressive threshold for comparison. In addition, defining the control group through an income range which is further away from the threshold, is a way to ensure the control group was not affected by the treatment. Taxpayers with incomes closer to the threshold moving to Obwalden may have made the moving decision thinking they would benefit from the low tax rates, but miscalculated their taxable income as it is calculated in Obwalden, or they were too optimistic about the income they would realize in that year.

Overall the number of in-comers in the treatment and control group is very small and therefore more noisy than the series of the total number of taxpayers. This also affects the trends prior to the reform. While in all four panels of Figure 13 the common trend assumption holds, there is more noise in the case of the in-comers compared to the full set of residents. The number of in-comers depicted in Figure 13 is potentially downward biased. The register data only record the last move of a taxpayer. Since the data were exported in 2012 (when tax records up to 2010 were definitively assessed), households who moved within the canton between 2006 and 2012 do not show up as in-comers from outside anymore. In the stock of rich taxpayers, however, there are only 
a handful of observations with a moving date after 2005 and for which the canton of origin is Obwalden, thereby indicating that new arriving taxpayers did not move around substantially within Obwalden.

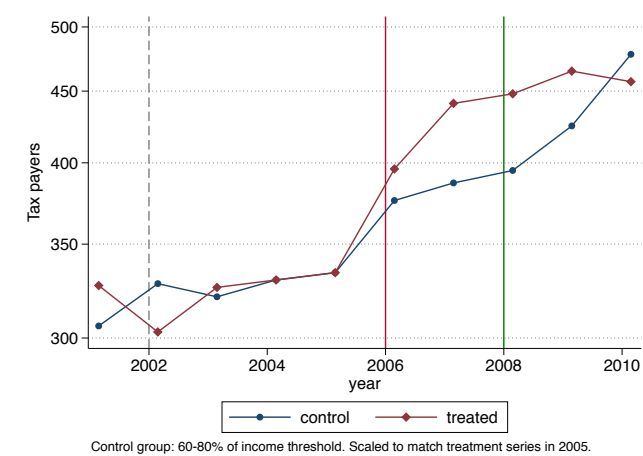

(a) Residents, $60-80 \%$

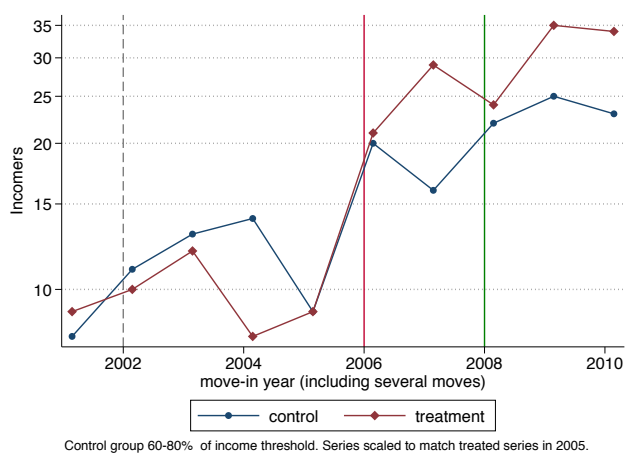

(c) Inmovers, $60-80 \%$

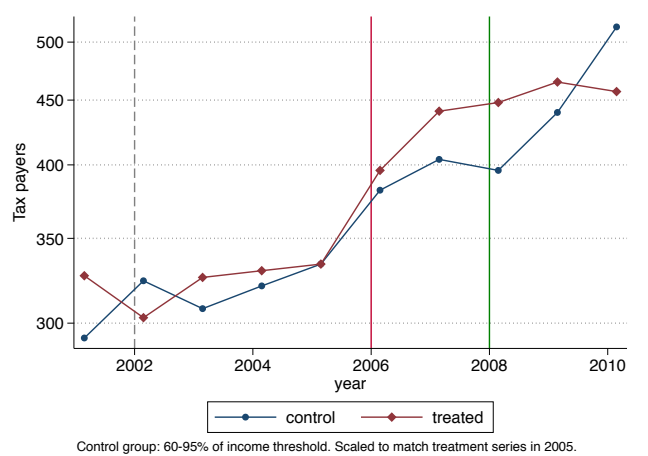

(b) Residents, 60-95\%

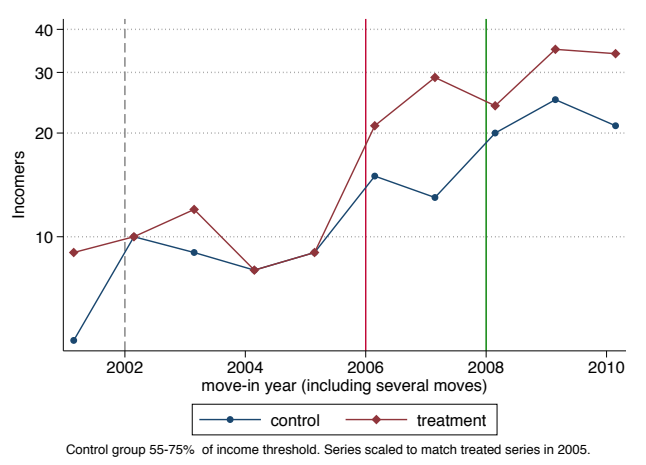

(d) Inmovers, $55-75 \%$

Figure 13: Control vs. treatment groups, 2001-2010

Note: The percentages indicate how the control group is defined in each panel in terms rate-determining income relative to the regressive threshold of 300,000 CHF. 60-80\%, for example, means that taxpayers with incomes of 180,000-240,000 CHF fall into the control group. The treatment group is always defined as taxpayers above the threshold of 300,000 CHF.

Source: Personal income and wealth tax data Obwalden, 2001-2010.

Table 3 presents descriptive statistics for the treatment and control groups of both, the stock and the inflow of rich taxpayers, respectively. While treatment and control groups differ from the total flow and stock, respectively, they are similar to each other in most characteristics. Taxpayers in the group of treated are more likely to be foreigners, and they depend more heavily on capital income and self-employment, but less on employment than the control group. These differences in the income composition, however, arise from how the treatment is designed. By aiming at top earners, the treatment group will almost by definition depend more heavily on capital than on labor incomes, since this is a feature 
generally observed at the top of the income distribution across space and time in capitalist societies.

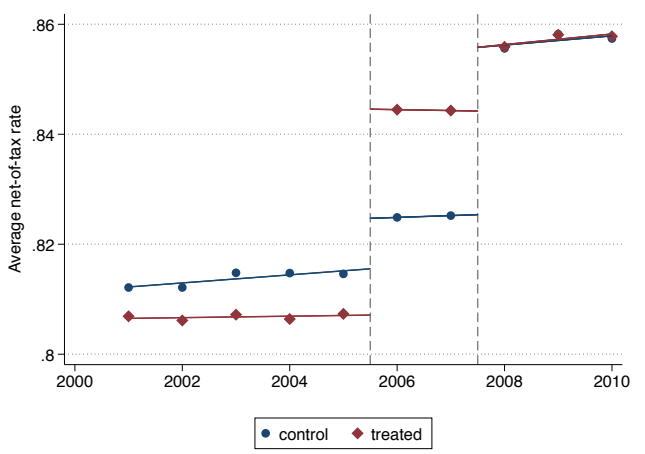

(a) Residents

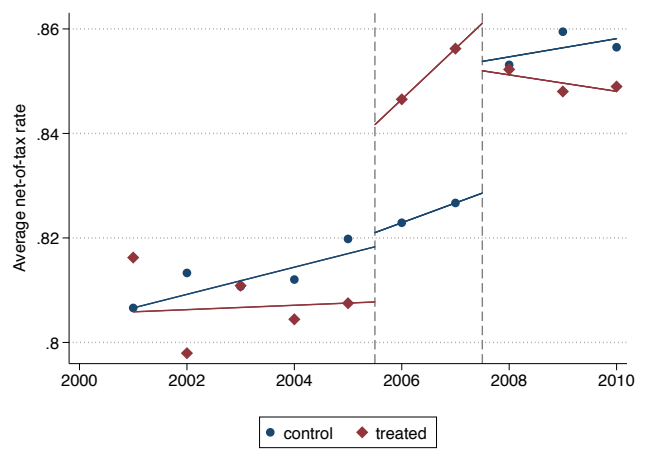

(b) In-comers

Figure 14: Average net-of-tax rates in control and treatment groups, 2001-2008

Note: Binned scatter plots with regression discontinuities in 2005.5 and 2007.5. Control group defined as having rate-determining income of 180,000-240,000 CHF, corresponding to $60-80 \%$ of the regressive threshold. The treatment group are taxpayers with incomes above the threshold of 300,000 CHF.

Source: Personal income and wealth tax data canton Obwalden, 2001-2010.

Figure 14 shows the variation in the average net-of-tax rates (i.e., $1-\bar{\tau}$ ) of the income tax, created by the reform. While before the reform the treated had lower net-of-tax rates than taxpayers in the control group, this relation was reversed with the regressive income tax. The treated residents (Panel a) faced an increase of $\simeq 4 \%$ in their average net-of-tax tax rate. The introduction of the flat rate tax in 2008 equalized the net-of-tax rate across individuals. The upward sloping curves in Panel b) suggest that in-comers selected into low-tax municipalities. Especially for the (small) group of treated in-comers the average net-of-tax rate was remarkably higher in 2007 than in 2006. This increase can further be explained by the fact that the average in-comer of 2007 in this group was richer than those coming before and after, therefore benefiting more extensively from the regressive tax scheme.

Figure 15 shows the distribution of taxpayers by their canton of origin. Most incomers lived in another Swiss canton before moving to Obwalden, yet still almost $15 \%$ of all in-comers moved in from abroad (category A). While there are in-comers from every canton in each year (not depicted in Figure 15), there are cantons from which a significantly higher share of in-comers originated, such as Lucerne (LU), Nidwalden (NW) and Zurich (ZH). Not surprisingly, these cantons are either direct neighbors (LU and NW) or, in the case of Zurich and Aargau (AG) at least relatively close by and have a large total population. In the case of the latter two, the share of treated in-comers is 
Table 3: Characteristics of treatment and control groups, 2001-2010

\begin{tabular}{|c|c|c|c|c|c|c|c|}
\hline & \multicolumn{3}{|c|}{ All Taxpayers } & \multicolumn{4}{|c|}{ New In-comers } \\
\hline & Treated & $\begin{array}{l}\text { Control } \\
60-80 \%\end{array}$ & Total & Treated & $\begin{array}{l}\text { Control } \\
55-75 \%\end{array}$ & $\begin{array}{l}\text { Control } \\
60-80 \%\end{array}$ & Total \\
\hline \multicolumn{8}{|l|}{ Tax burden } \\
\hline $\operatorname{NTR}(t<2006), \%$ & $\begin{array}{l}80.7 \\
(0.98)\end{array}$ & $\begin{array}{c}81.4 \\
(0.97)\end{array}$ & $\begin{array}{c}87.9 \\
(4.79)\end{array}$ & $\begin{array}{c}80.7 \\
(0.79)\end{array}$ & $\begin{array}{c}81.5 \\
(0.93)\end{array}$ & $\begin{array}{c}81.3 \\
(1.09)\end{array}$ & $\begin{array}{c}87.6 \\
(4.56)\end{array}$ \\
\hline $\operatorname{NTR}\left(t \geq 2006^{*}\right), \%$ & $\begin{array}{l}84.4 \\
(1.87)\end{array}$ & $\begin{array}{l}82.5 \\
(0.89)\end{array}$ & $\begin{array}{l}88.8 \\
(4.69)\end{array}$ & $\begin{array}{l}84.6 \\
(2.07)\end{array}$ & $\begin{array}{l}82.6 \\
(0.49)\end{array}$ & $\begin{array}{l}82.5 \\
(0.73)\end{array}$ & $\begin{array}{l}88.5 \\
(4.83)\end{array}$ \\
\hline Wealth tax $(t<2006), \%$ & $\begin{array}{c}0.413 \\
(0.023)\end{array}$ & $\begin{array}{l}0.413 \\
(0.02)\end{array}$ & $\begin{array}{c}0.416 \\
(0.035)\end{array}$ & $\begin{array}{c}0.416 \\
(0.015)\end{array}$ & $\begin{array}{c}0.413 \\
(0.015)\end{array}$ & $\begin{array}{c}0.414 \\
(0.016)\end{array}$ & $\begin{array}{l}0.413 \\
(0.04)\end{array}$ \\
\hline Wealth $\operatorname{tax}\left(t \geq 2006^{*}\right), \%$ & $\begin{array}{c}0.282 \\
(0.059)\end{array}$ & $\begin{array}{c}0.293 \\
(0.038)\end{array}$ & $\begin{array}{c}0.285 \\
(0.022)\end{array}$ & $\begin{array}{c}0.278 \\
(0.054)\end{array}$ & $\begin{array}{c}0.292 \\
(0.042)\end{array}$ & $\begin{array}{c}0.303 \\
(0.06)\end{array}$ & $\begin{array}{c}0.286 \\
(0.026)\end{array}$ \\
\hline \multicolumn{8}{|l|}{ Household characteristics } \\
\hline Female & $\begin{array}{c}0.082 \\
(0.274)\end{array}$ & $\begin{array}{c}0.083 \\
(0.276)\end{array}$ & $\begin{array}{c}0.305 \\
(0.468)\end{array}$ & $\begin{array}{c}0.062 \\
(0.242)\end{array}$ & $\begin{array}{c}0.048 \\
(0.215)\end{array}$ & $\begin{array}{l}0.061 \\
(0.24)\end{array}$ & $\begin{array}{c}0.347 \\
(0.476)\end{array}$ \\
\hline Age & $\begin{array}{c}59.670 \\
(12.6)\end{array}$ & $\begin{array}{c}57.030 \\
(12.62)\end{array}$ & $\begin{array}{l}48.440 \\
(19.83)\end{array}$ & $\begin{array}{l}52.080 \\
(10.86)\end{array}$ & $\begin{array}{r}49.460 \\
(11.08)\end{array}$ & $\begin{array}{l}49.470 \\
(11.16)\end{array}$ & $\begin{array}{c}43.260 \\
(15.9)\end{array}$ \\
\hline Married & $\begin{array}{c}0.773 \\
(0.419)\end{array}$ & $\begin{array}{c}0.769 \\
(0.422)\end{array}$ & $\begin{array}{c}0.467 \\
(0.499)\end{array}$ & $\begin{array}{c}0.767 \\
(0.424)\end{array}$ & $\begin{array}{c}0.745 \\
(0.437)\end{array}$ & $\begin{array}{c}0.756 \\
(0.431)\end{array}$ & $\begin{array}{c}0.442 \\
(0.497)\end{array}$ \\
\hline Double earners & $\begin{array}{c}0.422 \\
(0.494)\end{array}$ & $\begin{array}{c}0.483 \\
(0.5)\end{array}$ & $\begin{array}{l}0.214 \\
(0.41)\end{array}$ & $\begin{array}{c}0.430 \\
(0.496)\end{array}$ & $\begin{array}{c}0.476 \\
(0.501)\end{array}$ & $\begin{array}{c}0.458 \\
(0.5)\end{array}$ & $\begin{array}{c}0.160 \\
(0.366)\end{array}$ \\
\hline Swiss citizen & $\begin{array}{c}0.865 \\
(0.342)\end{array}$ & $\begin{array}{c}0.919 \\
(0.273)\end{array}$ & $\begin{array}{c}0.929 \\
(0.257)\end{array}$ & $\begin{array}{c}0.696 \\
(0.462)\end{array}$ & $\begin{array}{c}0.705 \\
(0.458)\end{array}$ & $\begin{array}{l}0.678 \\
(0.47)\end{array}$ & $\begin{array}{c}0.853 \\
(0.355)\end{array}$ \\
\hline Moved-in from abroad & $\begin{array}{c}0.130 \\
(0.337)\end{array}$ & $\begin{array}{c}0.089 \\
(0.285)\end{array}$ & $\begin{array}{c}0.065 \\
(0.246)\end{array}$ & $\begin{array}{l}0.115 \\
(0.32)\end{array}$ & $\begin{array}{c}0.080 \\
(0.273)\end{array}$ & $\begin{array}{c}0.120 \\
(0.326)\end{array}$ & $\begin{array}{c}0.134 \\
(0.341)\end{array}$ \\
\hline Employment & & & & & & & \\
\hline Employee & $\begin{array}{c}0.517 \\
(0.5)\end{array}$ & $\begin{array}{c}0.550 \\
(0.498)\end{array}$ & $\begin{array}{c}0.608 \\
(0.488)\end{array}$ & $\begin{array}{c}0.637 \\
(0.482)\end{array}$ & $\begin{array}{c}0.772 \\
(0.421)\end{array}$ & $\begin{array}{l}0.740 \\
(0.44)\end{array}$ & $\begin{array}{c}0.780 \\
(0.414)\end{array}$ \\
\hline Self employed & $\begin{array}{l}0.153 \\
(0.36)\end{array}$ & $\begin{array}{c}0.148 \\
(0.355)\end{array}$ & $\begin{array}{c}0.059 \\
(0.236)\end{array}$ & $\begin{array}{c}0.067 \\
(0.251)\end{array}$ & $\begin{array}{c}0.041 \\
(0.2)\end{array}$ & $\begin{array}{l}0.061 \\
(0.24)\end{array}$ & $\begin{array}{c}0.059 \\
(0.235)\end{array}$ \\
\hline Retiree & $\begin{array}{c}0.131 \\
(0.337)\end{array}$ & $\begin{array}{c}0.139 \\
(0.346)\end{array}$ & $\begin{array}{c}0.217 \\
(0.413)\end{array}$ & $\begin{array}{c}0.052 \\
(0.222)\end{array}$ & $\begin{array}{c}0.062 \\
(0.242)\end{array}$ & $\begin{array}{c}0.069 \\
(0.254)\end{array}$ & $\begin{array}{c}0.096 \\
(0.295)\end{array}$ \\
\hline $\begin{array}{l}\text { Share of income from: } \\
\text { emplyoment }\end{array}$ & $\begin{array}{c}0.317 \\
(0.349)\end{array}$ & $\begin{array}{c}0.440 \\
(0.378)\end{array}$ & $\begin{array}{c}0.580 \\
(0.685)\end{array}$ & $\begin{array}{c}0.455 \\
(0.394)\end{array}$ & $\begin{array}{c}0.613 \\
(0.362)\end{array}$ & $\begin{array}{c}0.590 \\
(0.369)\end{array}$ & $\begin{array}{c}0.681 \\
(0.969)\end{array}$ \\
\hline self-employment & $\begin{array}{c}0.185 \\
(0.327)\end{array}$ & $\begin{array}{c}0.144 \\
(0.291)\end{array}$ & $\begin{array}{c}0.038 \\
(24.28)\end{array}$ & $\begin{array}{l}0.131 \\
(0.29)\end{array}$ & $\begin{array}{c}0.118 \\
(0.264)\end{array}$ & $\begin{array}{c}0.130 \\
(0.284)\end{array}$ & $\begin{array}{l}-1.719 \\
(130.9)\end{array}$ \\
\hline capital & $\begin{array}{c}0.484 \\
(0.389)\end{array}$ & $\begin{array}{c}0.347 \\
(0.315)\end{array}$ & $\begin{array}{c}0.139 \\
(19.52)\end{array}$ & $\begin{array}{c}0.440 \\
(0.441)\end{array}$ & $\begin{array}{c}0.246 \\
(0.292)\end{array}$ & $\begin{array}{l}0.262 \\
(0.3)\end{array}$ & $\begin{array}{c}1.372 \\
(91.75)\end{array}$ \\
\hline $\begin{array}{l}\text { Major income source: } \\
\text { employment }\end{array}$ & $\begin{array}{c}0.297 \\
(0.457)\end{array}$ & $\begin{array}{c}0.453 \\
(0.498)\end{array}$ & $\begin{array}{c}0.592 \\
(0.491)\end{array}$ & $\begin{array}{c}0.460 \\
(0.5)\end{array}$ & $\begin{array}{c}0.655 \\
(0.477)\end{array}$ & $\begin{array}{c}0.641 \\
(0.481)\end{array}$ & $\begin{array}{c}0.683 \\
(0.465)\end{array}$ \\
\hline self-employment & $\begin{array}{c}0.169 \\
(0.442)\end{array}$ & $\begin{array}{l}0.130 \\
(0.41)\end{array}$ & $\begin{array}{c}0.047 \\
(0.272)\end{array}$ & $\begin{array}{c}0.121 \\
(0.372)\end{array}$ & $\begin{array}{c}0.099 \\
(0.363)\end{array}$ & $\begin{array}{c}0.108 \\
(0.379)\end{array}$ & $\begin{array}{c}0.041 \\
(0.264)\end{array}$ \\
\hline capital income & $\begin{array}{c}0.443 \\
(0.533)\end{array}$ & $\begin{array}{c}0.279 \\
(0.498)\end{array}$ & $\begin{array}{c}0.062 \\
(0.321)\end{array}$ & $\begin{array}{c}0.368 \\
(0.526)\end{array}$ & $\begin{array}{c}0.127 \\
(0.517)\end{array}$ & $\begin{array}{c}0.131 \\
(0.504)\end{array}$ & $\begin{array}{c}0.082 \\
(0.357)\end{array}$ \\
\hline Observations & 3,827 & 3,150 & 235,867 & 193 & 145 & 131 & 7,682 \\
\hline
\end{tabular}

Note: Sample means, standard errors in parentheses. NTR: average net-of-tax rate, i.e. $(1-\bar{\tau})$. *: 2006-2007; afterwards, income and wealth tax rates are virtually identical for everyone. Source: Personal income and wealth tax data canton Obwalden, 2001-2010. 
larger than the total share of in-movers over the period 2001-2010.

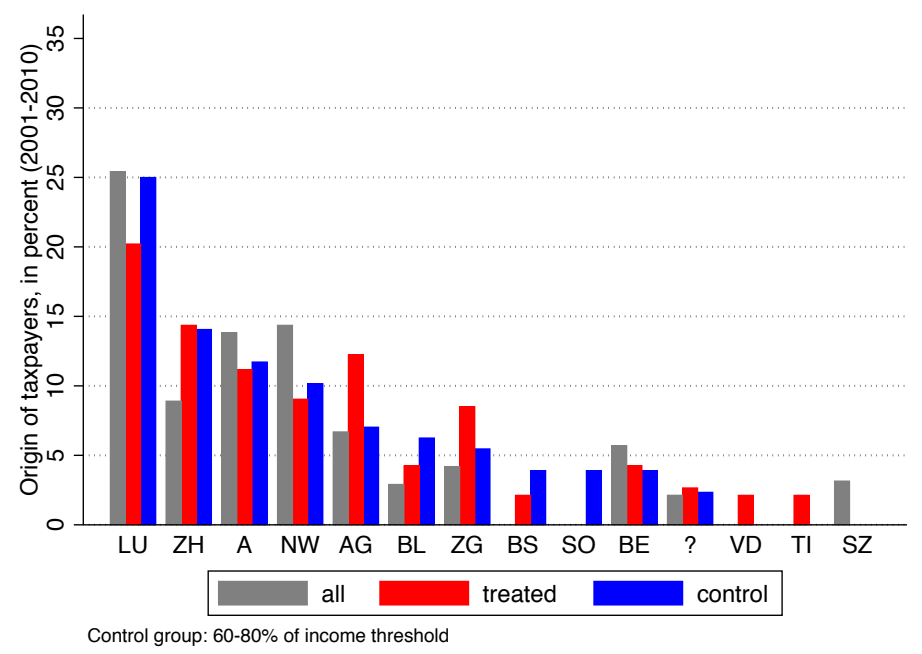

Figure 15: Origin of taxpayers who moved to Obwalden, 2001-2010

Note: Treated are taxpayers with rate-determining income $>300,000 \mathrm{CHF}$, in the control group are all taxpayer with rate-determining income of 180,000-240,000 CHF (corresponding to $60-80 \%$ of the regressive threshold). A stands for in-comers coming from abroad. Origin is irrespective of the nationality, so coming from A is not mean foreigners, and in-comers from other cantons are not necessarily Swiss nationals. The origin is only recorded for the last move, such that the origin before first moving to Obwalden gets lost once taxpayers move within the canton. Taxpayers who have Obwalden as origin are excluded, as they were either born in Obwalden or moved within Obwalden.

Source: Personal income and wealth tax data Obwalden, 2001-2010.

Table B4 in the Appendix further shows the distribution of the origin of taxpayers in the control and treatment groups, respectively, before and after the treatment. While overall there where no shifts in the origin of taxpayers (last two columns of Table B4), the composition of the treatment and the control groups experienced some changes. In the treatment group the share of taxpayers coming from Zurich, Bern (BE), and from abroad has increased in the post-reform years, while the share of in-comers from of the closest neighbors Lucerne, Nidwalden, and Zug, has decreased. This suggests that the reform did not just attract taxpayers living close by, but also those coming from further away, including those from abroad.

\subsubsection{Estimation and results}

Table 4 presents elasticity and reduced form estimates for the total number of rich taxpayers (corresponding to Panels a) and b) of Figure 13), and the number of rich taxpayers moving to Obwalden (corresponding to Panels c) and d) of Figure 13). The reduced form estimations, presented in Columns 1 and 2 of Table 4, are estimated using the following specification. Collapsing the data into year $t$, group $i=\{0,1\}$ cells allows for a simple 
DiD model of the form:

$$
N_{i, t}=\alpha+\beta \cdot(T R \cdot P R)+\lambda \cdot T R+\gamma_{t}+\epsilon_{i, t} \quad,
$$

where $N_{i, t}$ denotes the number of taxpayers in group $i, T R=\mathbb{1}[i=1]$ is the treatment group dummy, $P R=\mathbb{1}[t \geq 2006]$ is the post-reform dummy, and $\gamma_{t}$ are year fixed effects. The coefficient of interest $\beta$ is the DiD estimator on the average annual increase in the number of residents or in-comers, respectively, after the introduction of the tax reform in 2006. I exclude the years after 2007 and hence the 2008 flat rate tax reform from the estimation, since presumably the control group responded to the second reform. With seven years of observations, five pre- and two post-reform, and two groups, this leads to 14 group-year cells for the regression analysis. In Column 2 of Table 4, the dependent variable is the log number of residents or in-comers, respectively, allowing for an interpretation in percentage changes.

The elasticities of the number of rich taxpayers with respect to the net-of-tax rate are estimated using a 2SLS approach (following Kleven et al., 2014). Again I collapse the data into year-group cells for the period 2001-2007. The second stage takes on the form:

$$
\log N_{i, t}=\alpha+\varepsilon \cdot \log \left(1-\tau_{i, t}\right)+\beta \cdot T R+\gamma_{t}+\epsilon_{i, t} \quad,
$$

where $\left(1-\tau_{i, t}\right)$ is the net-of-tax rate of group $i$. Depending on the specification, I estimate the elasticity $\varepsilon$ with respect to the average or the marginal net-of-tax rate. In the first stage, I instrument for the respective net-of-tax rate with the treatment interaction dummy $D i D_{2006}=T R \cdot \mathbb{1}[t \geq 2006]$. The first stage therefore takes on the form:

$$
\log \left(1-\tau_{i, t}\right)=\beta \cdot D i D_{2006}+\lambda \cdot T R+\gamma_{t}+u_{i, t} .
$$

In a second set of regressions I add an instrument for the 2008 reform to equation (11) to make use of the whole time frame available. The first stage is therefore modified to:

$$
\log \left(1-\tau_{i, t}\right)=\beta_{1} \cdot D i D_{2006}+\beta_{2} \cdot D i D_{2008}+\lambda \cdot T R+\gamma_{t}+u_{i, t} .
$$

DiD $D_{2006}=T R \cdot \mathbb{1}[2006 \leq t<2008]$ is the original DiD treatment interaction dummy, and $D i D_{2008}=T R \cdot \mathbb{1}[t \geq 2008]$ identifies the second reform.

The results for the stock of rich taxpayers are reported in Panel A of Table $4 .{ }^{19}$ The reduced form estimates suggest that in the first two years after the introduction of the regressive tax the number of taxpayers increased by 37 , or by $6.3 \% . \varepsilon_{\tau}$ denotes the

\footnotetext{
${ }^{19}$ Detailed regression results are reported in tables B5, B6, and B7 in the Appendix.
} 
elasticity with respect to the marginal tax rate, $\varepsilon_{\bar{\tau}}$ stands for the elasticity with respect to the average tax rate. The corresponding short run elasticity with respect to the marginal net-of-tax rate, $\varepsilon_{\tau}$, is 0.76 (Column 3 ). The elasticity with respect to average net-of-tax rate, $\varepsilon_{\bar{\tau}}$, is 1.94 (Column 4) and therefore above the short-run elasticity estimates found in Kleven et al. (2014), which are in the range of 1.3 to 1.8. The medium-run elasticity, based on the estimation with an instrument for each of the two reforms, leads to very similar yet less precise point estimates.

Columns 5 and 6 of Table 4 further show how the definition of the control group can influence the resulting estimates. In correspondence with Panel b) of Figure 13, the control group is redefined containing taxpayers with rate-determining income of 180,000-285,000 CHF (or $60-95 \%$ of the regressive income threshold). The corresponding estimates are all larger than in the baseline estimates. Interestingly, however, the (statistically not significant) reduced form estimate in Column 5 is substantially smaller than the one in Column 1. Since this control group seems to have responded even more to the 2006 and especially the 2008 reforms, these estimates have to be taken as lower bounds, even though they are already large. Overall, the estimates with respect to the marginal netof-tax rate are all in the upper range or above those of Kleven et al. (2014), who define the control group as having incomes between $80-99 \%$ of the qualifying income threshold.

Panel B of Table 4 reports analogous results for the annual inflow of taxpayers moving into Obwalden. The reduced form estimate in Column 1 suggests that roughly 8 rich taxpayers more arrived in each of the two post reform years 2006 and 2007. While this may seem negligible, this corresponds to an increase in the number of rich in-movers of almost $34 \%$ when estimated in logs (Column 2), although this coefficient is not statistically significant. The corresponding elasticities are very large, which can be explained by the small number of taxpayers in each year-group cell: one additionally attracted rich taxpayer corresponds to and increase of $10 \%$ in 2005. Therefore, and because they are not very precisely estimated, these estimates should be taken with a grain of salt.

Again the use of a different control group affects the size and precision of the estimates. As shown in Figure 13, Panel d), defining the control group as having income between $55 \%$ to $75 \%$ of the threshold may be more appropriate to avoid using a control group which is potentially contaminated by the treatment. Indeed the estimates become more precise, yet they are again even larger. The elasticity of in-comers with respect to the average net-of-tax rate lies between 9.7 and 11.8, which is about 6 times larger than the corresponding estimates of new arrivals in Kleven et al. (2014). The fact that the estimates are smaller in the medium run than in the short run in all specifications suggests 
that moving responses were strongest right after the introduction of the reform.

For all IV regressions, the first stage is highly significant and strong, with large $\mathrm{R}^{2}$ and $\chi^{2}$ statistics. Following the approach by Kleven et al. (2014) allows for direct comparison of these results, by ensuring that differences are not method driven. A robustness check using simple OLS, however, leads to almost identical elasticites. This suggests that endogeneity is not an issue here, which is supported by Hausman tests for exogeneity, reported in tables B5, B6, and B7 in the Appendix. As a further robustness check I have run the the regressions reported in Table 4 with the share of taxpayers in each year-group cell in terms of the corresponding years' total number of taxpayers in the canton. These estimates, reported in Table B8, are again virtually identical to the ones reported in Table 4 .

The large elasticities found here are the result of the small size of the canton and residency-based taxation (as opposed to taxation at the source). Also, with the Agreement on Free Movement of Labor with the European Union the pool of potential inmovers to Obwalden is large. The estimates serve as a reference point for other, small jurisdictions, especially within border regions, in a setting of residence-based taxation and no restrictions on migration. They show that given the absence of restrictions, workers willingness to relocate is high. 
Table 4: Difference-in-Differences of taxpayers in Obwalden

\begin{tabular}{cccccc}
\hline$(1)$ & $(2)$ & $(3)$ & $(4)$ & $(5)$ & $(6)$ \\
Reduced & Reduced & 2SLS & 2SLS & 2SLS & 2SLS \\
$(\operatorname{level})$ & $(\log )$ & $(\log )$ & $(\log )$ & $(\log )$ & $(\log )$ \\
\hline
\end{tabular}

Panel A

Stock of taxpayers (all residents and in-comers)

\begin{tabular}{|c|c|c|c|c|c|c|}
\hline Control group & & $60-8$ & & & 60 & $5 \%$ \\
\hline$D i D_{2006}$ & $\begin{array}{c}36.800^{*} \\
(15.285)\end{array}$ & $\begin{array}{c}0.061 \\
(0.047)\end{array}$ & & & $\begin{array}{c}17.300 \\
(16.730)\end{array}$ & $\begin{array}{c}0.074 \\
(0.047)\end{array}$ \\
\hline$\varepsilon_{\tau}(2006-07)$ & & & $\begin{array}{c}0.762^{* *} \\
(0.350)\end{array}$ & & $\begin{array}{c}0.926^{* * *} \\
(0.350)\end{array}$ & \\
\hline$\varepsilon_{\bar{\tau}}(2006-07)$ & & & & $\begin{array}{c}1.937^{* *} \\
(0.885)\end{array}$ & & $\begin{array}{c}2.371^{* * *} \\
(0.885)\end{array}$ \\
\hline$\varepsilon_{\tau}(2006-10)$ & & & $\begin{array}{l}0.721^{*} \\
(0.425)\end{array}$ & & $\begin{array}{c}0.688 \\
(0.458)\end{array}$ & \\
\hline$\varepsilon_{\bar{\tau}}(2006-10)$ & & & & $\begin{array}{l}1.941^{*} \\
(1.139)\end{array}$ & & $\begin{array}{l}2.310^{*} \\
(1.192)\end{array}$ \\
\hline$\Delta \tau(\% \mathrm{pts})$ & 3.760 & & & & & \\
\hline
\end{tabular}

\section{Panel B}

Flow of taxpayers (in-comers only)

\begin{tabular}{|c|c|c|c|c|c|c|}
\hline Control group & & $60-$ & & & & $75 \%$ \\
\hline$D_{i} D_{2006}$ & $\begin{array}{l}8.400^{*} \\
(3.764)\end{array}$ & $\begin{array}{c}0.291 \\
(0.298)\end{array}$ & & & $\begin{array}{c}9.600^{* *} \\
(3.021)\end{array}$ & $\begin{array}{l}0.446^{*} \\
(0.212)\end{array}$ \\
\hline$\varepsilon_{\tau}(2006-07)$ & & & $\begin{array}{c}3.744 \\
(2.278)\end{array}$ & & $\begin{array}{c}5.641^{* * *} \\
(1.509)\end{array}$ & \\
\hline$\varepsilon_{\bar{\tau}}(2006-07)$ & & & & $\begin{array}{l}7.652^{*} \\
(4.340)\end{array}$ & & $\begin{array}{c}11.760^{* * *} \\
(1.882)\end{array}$ \\
\hline$\varepsilon_{\tau}(2006-10)$ & & & $\begin{array}{c}2.416 \\
(1.939)\end{array}$ & & $\begin{array}{c}4.252^{* * *} \\
(1.495)\end{array}$ & \\
\hline$\varepsilon_{\bar{\tau}}(2006-10)$ & & & & $\begin{array}{c}5.142 \\
(3.837)\end{array}$ & & $\begin{array}{c}9.694^{* * *} \\
(2.492)\end{array}$ \\
\hline$\Delta \tau(\% \mathrm{pts})$ & 4.398 & & & & & \\
\hline
\end{tabular}

*** $\mathrm{p}<0.01,{ }^{* *} \mathrm{p}<0.05,{ }^{*} \mathrm{p}<0.1$

Note: All regressions contain year dummies, a treatment dummy, and a constant. Detailed regression results are reported in tables B5, B6, and B7 in the Appendix. Standard errors in parentheses.

Source: Personal income and wealth tax data Obwalden, 2001-2010.

\subsection{The Elasticity of Taxable Income at the Top}

Following the panel approach by Gruber and Saez (2002), I estimate the elasticity of taxable income for taxpayers with real incomes above 300,000 CHF, since for these income 
groups the tax cuts were remarkably large, not only in 2006 but also with the introduction of the flat rate tax in 2008. Abstracting from income effects leads to the following baseline panel specification

$$
\log \left(z_{i t_{2}} / z_{i t_{1}}\right)=e \cdot \log \left[\left(1-\tau_{t_{2}}\right) /\left(1-\tau_{t_{1}}\right)\right]+v_{i t},
$$

where $z_{i t_{1}}$ and $z_{i t_{2}}$ is reported income in year $t_{1}$ and $t_{2}$, respectively, and $e$ is the ETI. Note that OLS estimates of (13) are biased, as the term capturing the tax rate change is correlated with the error term $v_{i t}$. If there is a positive shock to income $\left(v_{i t}>0\right)$, then, due to the regressive scheme, the marginal tax rate $\tau$ decreases mechanically. Gruber and Saez (2002) propose as a natural instrument the predicted net-of-tax rate change if income does not change from year 1 to year 2 , i.e., $\log \left(1-\tau_{t_{2}}\left(z_{1}\right)\right)$.

Such an IV-estimation is still susceptible to bias, due to mean reversion (because of transitory incomes) and exogenous changes in the income distribution. Both result in a correlation between $z_{i t_{1}}$ and $v_{i t}{ }^{20}$ The solution proposed by Auten and Carroll (1999) and adopted in Gruber and Saez (2002) is to include a large set of base year (i.e., $t_{1}$ ) income controls. However, as Weber (2013) shows, base year incomes are still correlated with the error in a panel setting. She therefore suggests to use lagged base year income controls, $z_{i t_{1}-s}$. Having many years of data, it is possible to add a rich set of such controls, as the effects from mean reversion and changes in the income distribution are probably not linear. Therefore, in addition to log income in period $t_{1}-s$, a 10 -piece spline in lagged log base year income (i.e., a spline for each decile of the gross income distribution in $t_{1}-s$ ) is included, as in Gruber and Saez (2002). Because the endogeneity of $z_{i t_{1}}$ also affects the tax rate instrument, I use a lag of base year income to mitigate potential endogeneity bias, following Weber (2013).

I further include a vector of individual controls, $\mathbf{X}_{\mathbf{i t}}$, containing the age of the main taxpayer and a set of dummies for married, dependents, double-earners (married taxpayers only), retirees and self employed. Time dummies $\lambda_{t}$ control for period effects. Including all these covariates in equation (13), the econometric model reads as follows:

$$
\begin{array}{r}
\log \left(\frac{z_{i t_{2}}}{z_{i t_{1}}}\right)=\alpha_{0}+e \cdot \log \left[\frac{1-\tau_{t_{2}}\left(z_{1}\right)}{1-\tau_{t_{1}}\left(z_{1}\right)}\right]+\mathbf{X}_{\mathbf{i t}} \boldsymbol{\beta} \\
+\alpha_{1} \log \left(z_{i t_{1}-s}\right)+\sum_{k=1}^{10} \alpha_{2 k} S P L I N E_{k}\left(z_{i t_{1}-s}\right)+\lambda_{t}+v_{i t}
\end{array}
$$

This identification strategy relies on the assumption that mean reversion or changes in inequality are not correlated with year-specific tax changes, so that the relationship

\footnotetext{
${ }^{20}$ For an extensive discussion on consistent ETI estimates, circumventing the problems of mean reversion and exogenous income trends, see Weber (2013).
} 
between $z_{i t_{1}}$ and $v_{i t}$ remains constant over time (see Gruber and Saez, 2002, p.12). Since I am interested in the effect of the regressive income tax reform on the reported income, I restrict the sample to taxpayers who had rate-determining income larger than 300,000 $\mathrm{CHF}$ at least once in the sample period. Descriptives of the sample used for regression can be found in Table B9 in the Appendix.

Table 5: ETI: GMM IV regressions of taxable income on net-of-tax rate

\begin{tabular}{|c|c|c|c|c|c|c|}
\hline \multirow[b]{2}{*}{ Taxable income } & \multicolumn{2}{|c|}{ Baseline } & \multicolumn{2}{|c|}{ Base-year } & \multicolumn{2}{|c|}{ Splines } \\
\hline & (1) & $(2)$ & $(3)$ & $(4)$ & $(5)$ & (6) \\
\hline $\ln \Delta(1-\tau)$ & $\begin{array}{c}1.899 \\
(2.325)\end{array}$ & $\begin{array}{c}1.477 \\
(2.429)\end{array}$ & $\begin{array}{c}0.132 \\
(1.667)\end{array}$ & $\begin{array}{l}0.0174 \\
(1.518)\end{array}$ & $\begin{array}{c}0.127 \\
(1.646)\end{array}$ & $\begin{array}{c}0.246 \\
(1.446)\end{array}$ \\
\hline $\begin{array}{l}\text { Log lagged base-year } \\
\quad \text { income }(\Delta=3)\end{array}$ & & & $\begin{array}{c}-0.0588^{* * *} \\
(0.0116)\end{array}$ & $\begin{array}{c}-0.172^{* * *} \\
(0.0512)\end{array}$ & $\begin{array}{c}-0.268^{* * *} \\
(0.104)\end{array}$ & $\begin{array}{l}-0.251 \\
(0.212)\end{array}$ \\
\hline Married & & & $\begin{array}{c}0.0564 \\
(0.0480)\end{array}$ & omitted & $\begin{array}{c}0.0402 \\
(0.0489)\end{array}$ & omitted \\
\hline Double earners & & & $\begin{array}{c}0.0755 \\
(0.0477)\end{array}$ & $\begin{array}{c}0.412^{* * *} \\
(0.124)\end{array}$ & $\begin{array}{l}0.0925^{*} \\
(0.0481)\end{array}$ & $\begin{array}{c}0.422^{* * *} \\
(0.124)\end{array}$ \\
\hline HH with children & & & $\begin{array}{l}-0.0239 \\
(0.0470)\end{array}$ & $\begin{array}{l}0.00736 \\
(0.0983)\end{array}$ & $\begin{array}{r}-0.00391 \\
(0.0479)\end{array}$ & $\begin{array}{c}0.0161 \\
(0.0977)\end{array}$ \\
\hline Self employed & & & $\begin{array}{c}0.0655 \\
(0.0448)\end{array}$ & $\begin{array}{c}0.213 \\
(0.227)\end{array}$ & $\begin{array}{c}0.0466 \\
(0.0471)\end{array}$ & $\begin{array}{c}0.222 \\
(0.222)\end{array}$ \\
\hline Retiree & & & $\begin{array}{l}-0.0450 \\
(0.0673)\end{array}$ & $\begin{array}{c}-0.0872 \\
(0.140)\end{array}$ & $\begin{array}{l}-0.0599 \\
(0.0683)\end{array}$ & $\begin{array}{l}-0.116 \\
(0.136)\end{array}$ \\
\hline Age & & & $\begin{array}{l}-0.00110 \\
(0.00195)\end{array}$ & $\begin{array}{l}-0.0458 \\
(0.0598)\end{array}$ & $\begin{array}{c}-0.000531 \\
(0.00192)\end{array}$ & $\begin{array}{c}-0.0424 \\
(0.0596)\end{array}$ \\
\hline Municipality dummies & $\mathrm{N}$ & $\mathrm{N}$ & $\mathrm{Y}$ & omitted & $\mathrm{Y}$ & omitted \\
\hline Year dummies & $\mathrm{N}$ & $\mathrm{N}$ & $\mathrm{Y}$ & $\mathrm{Y}$ & $\mathrm{Y}$ & $\mathrm{Y}$ \\
\hline 10-piece income splines & $\mathrm{N}$ & $\mathrm{N}$ & $\mathrm{N}$ & $\mathrm{N}$ & $\mathrm{Y}$ & $\mathrm{Y}$ \\
\hline Individual fixed effect & $\mathrm{N}$ & $\mathrm{Y}$ & $\mathrm{N}$ & $\mathrm{Y}$ & $\mathrm{N}$ & $\mathrm{Y}$ \\
\hline Constant & $\begin{array}{l}0.00465 \\
(0.0447)\end{array}$ & & $\begin{array}{c}0.581^{* * *} \\
(0.211)\end{array}$ & & $\begin{array}{c}2.042^{* * *} \\
(0.785)\end{array}$ & \\
\hline Observations & 2,558 & 2,488 & 2,275 & 2,204 & 2,275 & 2,204 \\
\hline R-squared & & -0.020 & 0.028 & 0.042 & 0.037 & 0.048 \\
\hline $\mathrm{N}_{-}$clust & 534 & 464 & 509 & 438 & 509 & 438 \\
\hline Rank & 2 & 1 & 21 & 12 & 30 & 21 \\
\hline
\end{tabular}

*** $\mathrm{p}<0.01,{ }^{* *} \mathrm{p}<0.05,{ }^{*} \mathrm{p}<0.1$

Note: Sample restricted to taxpayers who have an income $>300,000 \mathrm{CHF}$ at least once in 2001-2010. Sample descriptives reported in Table B9 in the Appendix. Robust standard errors in parentheses.

Source: Personal income and wealth tax data Obwalden, 2001-2010. 
Table 6: ETI: GMM IV regressions of rate-determining income on net-of-tax rate

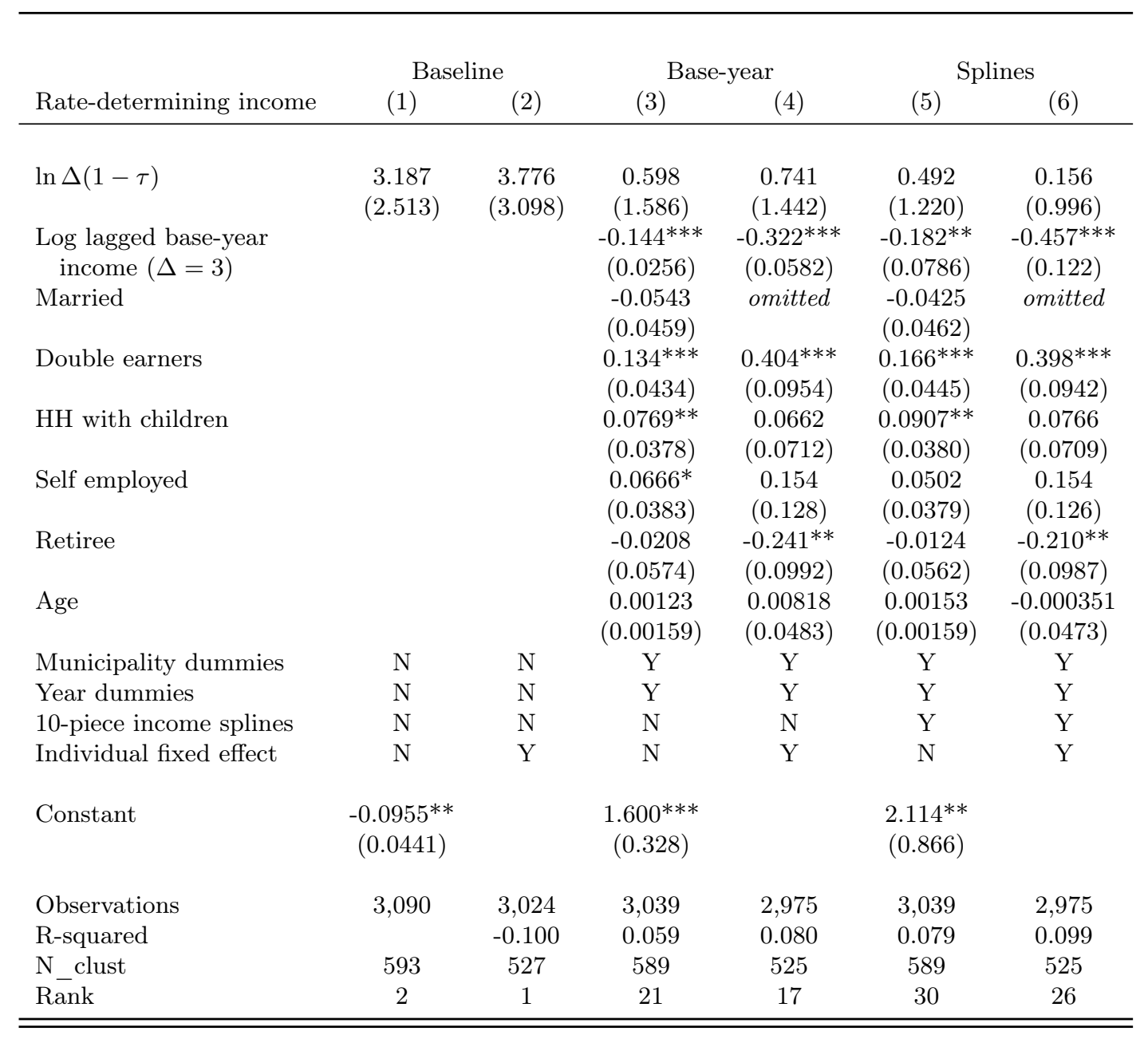

$* * * \mathrm{p}<0.01, * * \mathrm{p}<0.05, * \mathrm{p}<0.1$

Note: Sample restricted to taxpayers who have an income $>300,000 \mathrm{CHF}$ at least once in 2001-2010. Sample descriptives reported in Table B9 in the Appendix. Robust standard errors in parentheses.

Source: Personal income and wealth tax data Obwalden, 2001-2010.

Tables 5 and 6 report different specifications to estimate the elasticity of taxable and rate-determining income, respectively. Table 5 reports the baseline ETI estimates (Colmuns 1 and 2), along with estimates including a set of individual controls and baseyear income (Columns 3 and 4), and including 10-piece income splines (Columns 5 and 6). Even columns additionally include individual fixed effects. Point estimates are in the lower range of what other studies have found (see Gruber and Saez, 2002; Kleven et al., 2014), and are all statistically insignificant. The coefficient on lagged base yearincome on the other hand is significant in three out of four specifications, implying that there is mean-reversion in the income generating process at the top. The dummy for 
the top spline (not reported) is statistically significant and positive in models without fixed effects, but becomes insignificant once fixed effects are included. What is striking is the large and statistically significant coefficient on the dummy for double earners in the fixed effects models. This indicates that large adjustments happen for the second earners or, possibly, through changed marriage behavior. Especially for high income earners, mandatory joint tax filing of married couples is a disincentive to get married. With regressive tax rates at least high-income couples may benefit from marriage, and the discrimination of marriage vanishes completely with the introduction of the uniform flat rate tax in 2008. That second earners respond strongly to taxation is a channel which has found to be important in the literature on labor supply and taxation (Meghir and Phillips, 2010; Crossley and Jeon, 2007; Eissa and Hoynes, 2004). This moving from mandatory joint filing to individual taxation of married couples may therefore have large positive labor supply effects, given that the observed adjustments are the result of increased labor supply.

Table 6 presents the same set of specifications, but with changes in rate-determining income as dependent variables. Due to the distinction between taxable and rate-determining income, taxpayers have an incentive to adjust rate-determining income even more than taxable income. Indeed, point estimates for rate-determining income are higher, yet they remain statistically insignificant and are sensitive to specification. The described effect of double earner married couples remains large and statistically significant, even excluding individual specific fixed effects. Adjustment behavior of the household through the second earner therefore seems to be a particularly strong channel, much more than for example self-employment. This is somewhat surprising since the latter have usually been found to have particularly large behavioral responses to taxation. Also, in the estimation sample of top earners, around $20 \%$ of taxpayers are self-employed, about three times as many as in the whole population of taxpayers.

All these results, however, should be interpreted with prudence. Despite careful considerations of the specification, the identification strategy has turned out to be very sensitive. That the estimated elasticities remain statistically insignificant can be explained by the small sample size. This limitation, however, lies within the nature of the canton of Obwalden itself. Specifications including large parts of the population delivered statistically significant estimates, yet these were often completely out of range of what we might think of as a reasonable ETI and often had the wrong sign. 


\section{Conclusion}

In this paper I studied how responsive migration is to income and wealth tax cuts at the top. I address this question using quasi-experimental variation created by a two-step tax reform in the Swiss Canton of Obwalden. The aim of the reform explicitly was to first attract rich taxpayers, in order to afford an overall lower level of taxation in a second step.

Results show that the share of rich taxpayers living in the canton increased by remarkable $25-30 \%$ in the first five post-reform years. In addition, average incomes of the rich increased in Obwalden, suggesting that the group of rich in the canton grew larger and richer as a result of the reform. Elasticity estimates of the stock of rich taxpayers in the canton with respect to the average net-of-tax rate of lie in the range of 1.9-2.4. The corresponding elasticity of the inflow of rich taxpayers is even larger, ranging between 5.1 and 11.8 .

Indisputably, these elasticities are very large. Two factors help explain the strong measured responses. First, they are partly due to the small size of the canton, where a small increase in the number of in-comers corresponds to a large relative change. It lies in the nature of tax competition, and is in line with theory, that small jurisdictions will be more prone to engage in tax competition because their relative gains are large. Second, this paper highlights the importance of the institutional setting influencing moving elasticities of taxpayers. Given a residency-based income tax system, and that taxpayers are free to relocate to take advantage of low income taxes, they will try to do so to a larger extent than what we may have believed so far. This insight may further explain why in some settings the elasticity has found to be small, such as in Young and Varner (2011) and Young et al. (2014) in the US context. Not only are US states large and distances long. In addition, only some states have reciprocal agreements, allowing to tax individuals in their place of residency, resulting in source-based labor income taxation in most instances.

The findings imply that residence-based taxation, as opposed to source-based taxation, potentially comes at a high cost for the jurisdictions which lose out on their tax base. While source-based taxation could close this leakage of the tax base flowing to low-tax regions, it would at the same time create incentives for businesses to relocate. Reducing one distortion would worsen another. One possible solution to this problem is to combine source-based taxation with apportionment formulas, like it is currently done in many U.S. states. In this case, even if businesses do relocate, their tax liability 
remains partially in the state of origin, as a corporation's total profit is attributed to each jurisdiction, based, for example, on the proportion of sales. In such a small country like Switzerland, however, apportionment would likely bear very high administrative costs, cross-cantonal border shopping is extremely easy, and many firms generate a large share of sales abroad. For these reasons apportionment is not an attractive mechanism to limit the negative externalities of cantonal competition. The mechanism in place in Switzerland which does limit such negative externalities is the new fiscal equalization scheme between cantons and the federal government, "Neuer Finanzausgleich" (NFA), put in place in 2008.

The large tax changes in Obwalden may in addition have triggered adjustments in taxable income of taxpayers. Corresponding estimates of the elasticity of taxable income (ETI) with respect to the marginal net-of-tax rate are in range of what earlier studies have found for the U.S., and vary between 0.13 and 0.75 . However, the estimates are statistically insignificant and sensitive to specification. Nevertheless, all the ETI estimations indicate that especially married double earners respond strongly to taxation, a channel which has found to be important in the literature on labor supply and taxation. This suggests that moving from joint to single tax filing of married couples may have large positive labor supply effects.

Simple DiD estimates of the change in cantonal tax revenue due to the reform in Obwalden show how in comparison with almost every Swiss canton, the reform was at best revenue neutral. Despite the increase in the share of rich taxpayers after the reform, Obwalden was therefore not necessarily on the wrong side of the famous Laffer curve prior to the reform. The elasticity estimates suggest that in-migration and possibly retention of rich taxpayers were likely to have played an important role in absorbing the revenue losses caused by the reform. It is an exciting question for future research to assess whether the tax strategy of the canton of Obwalden has paid off in the long run and allowed the canton to reach a new, revenue-neutral equilibrium with lower taxes. 


\section{References}

Auten, G. and Carroll, R. (1999) The effect of income taxes on household income, The Review of Economics and Statistics, 81, 681-693.

Blundell, R. and MaCurdy, T. (1999) Labor Supply: A Review of Alternative Approaches, in Handbook of Labor Economics, Volume 3 (Eds.) O. Ashenfelter and D. Card, Elsevier Science B.V., vol. 3, chap. 27, pp. 1559-1695.

Crossley, T. F. and Jeon, S.-H. (2007) Joint Taxation and the Labour Supply of Married Women: Evidence from the Canadian Tax Reform of 1988, Fiscal Studies, 28, 343-365.

Eissa, N. and Hoynes, H. W. (2004) Taxes and the labor market participation of married couples: the earned income tax credit, Journal of Public Economics, 88, 1931-1958.

Feenberg, D. and Coutts, E. (1993) An Introduction to the TAXSIM Model, Journal of Policy Analysis and Management, 12, 189-194.

Feld, L. P. and Kirchgässner, G. (2001) Income tax competition at the State and Local Level in Switzerland, Regional Science and Urban Economics, 31, 181-213.

Föllmi, R. and Martínez, I. (2014) Volatile Top Income Shares in Switzerland? Reassessing the Evolution Between 1981 and 2009, CEPR Discussion Paper No. 10006, www.cepr.org/pubs/ dps/DP10006.asp.

Gruber, J. and Saez, E. (2002) The Elasticity of Taxable Income: Evidence and Implications, Journal of Public Economics, 84, 1-32.

Habermacher, F. and Kirchgässner, G. (2012) Asymmetric Tax Competition: Theoretical and Empirical Results, Mimeo, presented at the IIPF Annual Congress 2012.

Kirchgässner, G. and Pommerehne, W. W. (1996) European Union: Lessons from Switzerland, Journal of Public Economics, 60, 351-371.

Kleven, H. J., Landais, C. and Saez, E. (2013) Taxation and International Migration of Superstars: Evidence from the European Football Market, American Economic Review, 103, 1892-1924.

Kleven, H. J., Landais, C., Saez, E. and Schultz, E. A. (2014) Migration and Wage Effects of Taxing Top Earners: Evidence from the Foreigner Tax Scheme in Denmark, The Quarterly Journal of Economics, 129, 333-378.

Kleven, H. J. and Schultz, E. A. (2014) Estimating Taxable Income Responses Using Danish Tax Reforms, American Economic Journal: Economic Policy.

Liebig, T., Puhani, P. a. and Sousa-Poza, A. (2007) Taxation and Internal Migration? Evidence From the Swiss Census Using Community-Level Variation in Income Tax Rates, Journal of Regional Science, 47, 807-836.

Meghir, C. and Phillips, D. (2010) Labour Supply and Taxes, in Dimensions of Tax Design. The Mirrlees Review (Eds.) J. Mirrlees, S. Adam, T. Besley, R. Blundell, S. Bond, R. Chote, M. Gammie, P. Johnson, G. Myles and J. Poterba, Oxford University Press, chap. 3, pp. 202-274.

Morger, M. (2013) Heterogeneity in Income Tax Capitalization and Its Effects on Segregation within Switzerland, Eidgenössische Steuerverwaltung ESTV, Bern., http://www.estv.admin.ch/dokumentation/00075/00805/index.html?lang= de\&download=NHzLpZeg7t, Inp6IONTU04212Z61n1acy4Zn4Z2qZpn02Yuq2Z6gpJCDeIR7e2ym162epYbg2c _JjKbNoKSn6A--. 
Oates, W. E. (1969) The Effects of Property Taxes and Local Public Spending on Property Values: An Empirical Study of Tax Capitalization and the Tiebout Hypothesis, Journal of Political Economy, 77, 957-971.

Parchet, R. (2012) Are Local Tax Rates Strategic Complements or Strategic Substitutes?, European Regional Science Association ERSA, Conference Paper No. 12-313.

Piketty, T., Saez, E. and Stantcheva, S. (2014) Optimal Taxation of Top Labor Incomes: A Tale of Three Elasticities, American Economic Journal: Economic Policy, 6, 230-271.

Saez, E. (2013) Optimal progressive capital income taxes in the infinite horizon model, Journal of Public Economics, 97, 61-74.

Saez, E., Slemrod, J. and Giertz, S. H. (2012) The Elasticity of Taxable Income with Respect to Marginal Tax Rates: A Critical Review, Journal of Economic Literature, 50, 3-50.

Schaltegger, C., Somogyi, F. and Sturm, J.-E. (2011) Tax Competition and Income Sorting: Evidence from the Zurich Metropolitan Area, European Journal of Political Economy, 27, $455-470$.

Schmidheiny, K. (2006) Income Segregation and Local Progressive Taxation: Empirical Evidence from Switzerland, Journal of Public Economics, 90, 429-458.

Stadelmann, D. and Billon, S. (2012) Capitalisation of Fiscal Variables and Land Scarcity, Urban Studies, 49, 1571-1594.

Tiebout, C. M. (1956) A Pure Theory of Local Expenditures, Journal of Political Economy, 64, 416-424.

Train, K. E. (2009) Discrete Choice Methods with Simulation, Cambridge University Press, 2nd edn.

Weber, C. E. (2013) Toward Obtaining a Consistent Estimate of the Elasticity of Taxable Income Using Difference-in-Differences, working paper, department of Economics, University of Oregon.

Wilson, J. D. (1991) Tax competition with interregional differences in factor endowments, Regional science and Urban Economics, 21, 423-451.

Wilson, J. D. (1999) Theories of Tax Competition, National Tax Journal, pp. 269-304.

Winner, H. (2005) Has tax Competition Emerged in OECD Countries? Evidence from Panel Data, International Tax and Public Finance, 12, 667-687.

Young, C. and Varner, C. (2011) Millionaire Migration and State Taxation of Top Incomes: Evidence From a Natural Experiment, National Tax Journal, 64, 255-284.

Young, C., Varner, C., Lurie, I. and Prisinzano, R. (2014) Millionaire Migration and the Taxation of the Elite: Evidence from Administrative Data, mimeo, Stanford University. 


\section{Appendix A Cantonal and Municipality Income and Wealth Taxation in Switzerland}

The Swiss tax system is characterized by a strong degree of decentralization, and income is taxed at three levels: at the federal, the cantonal, and the municipality level. This federal system gives cantons and municipalities large autonomy in taxing residents' income and wealth (the latter is not taxed at the federal level). Each canton therefore has its own tax code, defining itemized and social deductions. These differ widely across cantons and hence so does taxable income. Cantonal taxable income also constitutes the tax base for municipality taxes.

The cantonal and municipality income and wealth taxes are determined in two steps. The cantonal law stipulates marginal tax rates which determine the socalled "simple tax".Figure A1 illustrates the changes in the marginal rate of the simple income and wealth tax for a single taxpayer between 1995 and 2010 in the canton of Obwalden. The effective cantonal and municipality taxes are then obtained by multiplying the simple tax by a cantonal and a municipality multiplier, respectively. This system allows cantons and municipalities regular adjustments to their revenue needs without need of going through the cumbersome work of adjusting the tax scheme. Since many cantons have some sort of balanced budget rule, multiplier are adjusted regularly. This is especially true for the municipality multipliers. Figure A2 depicts the changes in the cantonal and municipality multipliers in Obwalden, and Figure A3 finally shows the effective marginal income tax rates in all seven municipalities of the canton, after applying the cantonal and municipal multipliers. ${ }^{21}$ Married couples constitute a single tax unit, their incomes are therefore pooled together and no splitting factor is applied in Obwalden. There is only a married-specific and a double-earner deduction of taxable income as means to reduce the tax burden for these taxpayers.

\footnotetext{
${ }^{21}$ The procedure for the wealth tax is analogous.
} 


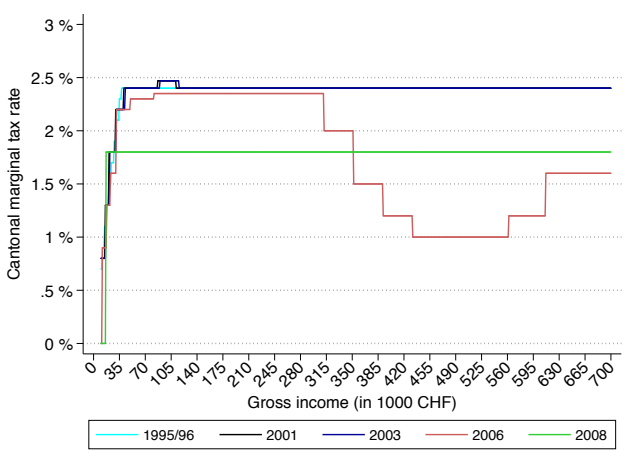

(a) Income tax

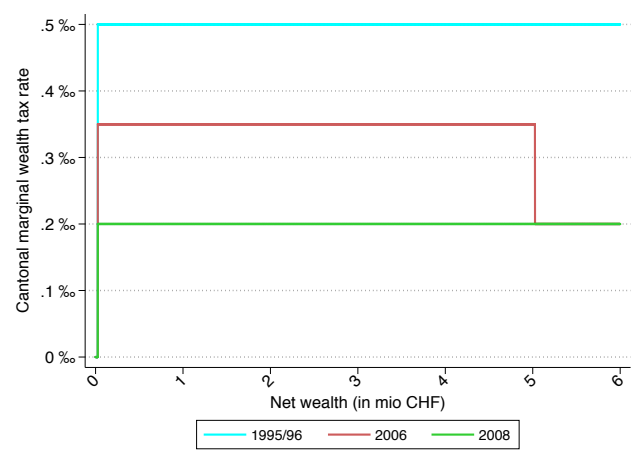

(b) Wealth tax

Figure A1: Simple income and wealth tax rates ("Einfache Steuer") in the Canton of Obwalden, 1995-2010

Note: Marginal tax rates for gross income / wealth of a single taxpayer. Own calculations.
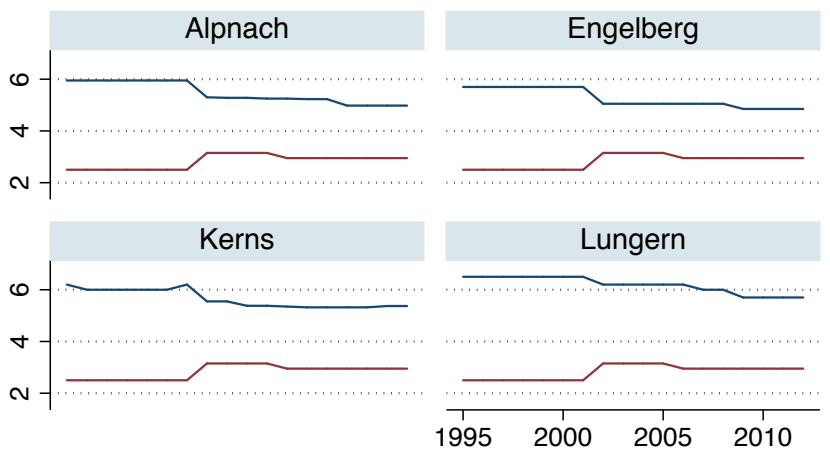

Sarnen

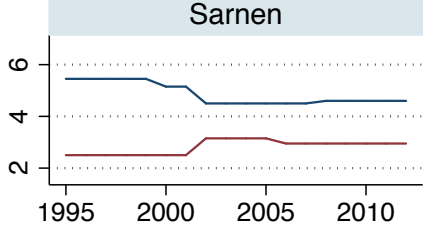

municipality tax multiplier
Engelberg
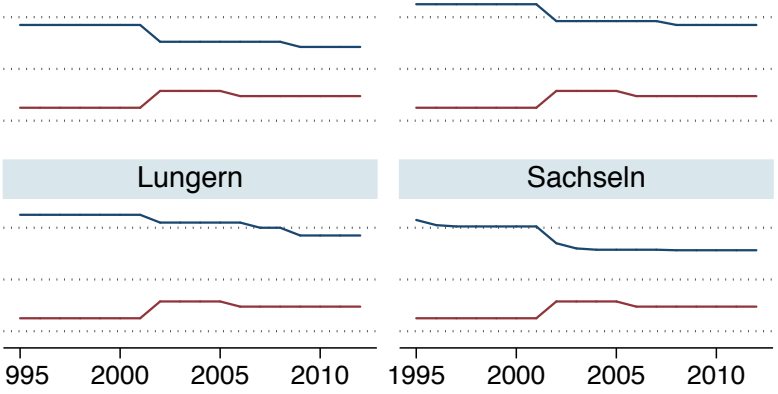

Giswil

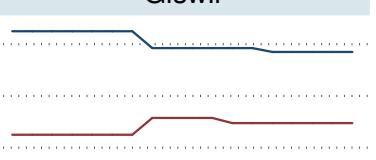

Graphs by municipality

Figure A2: Municipaltiy multipliers and cantonal tax multiplier OW, 1995-2013 Source: Federal Tax Administration ESTV and Parchet (2012) 


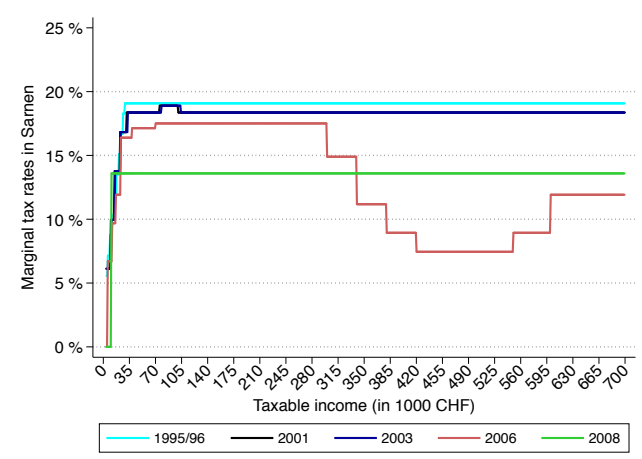

(a) Sarnen

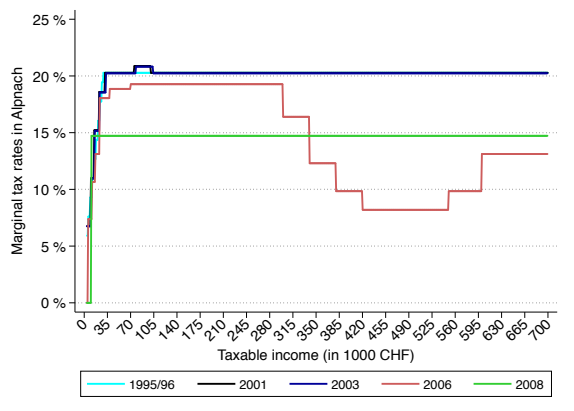

(b) Alpnach

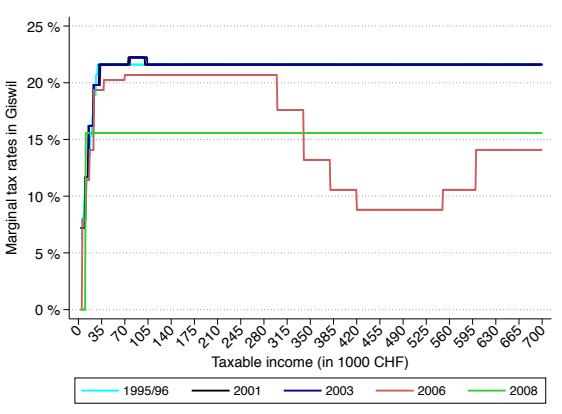

(d) Giswil

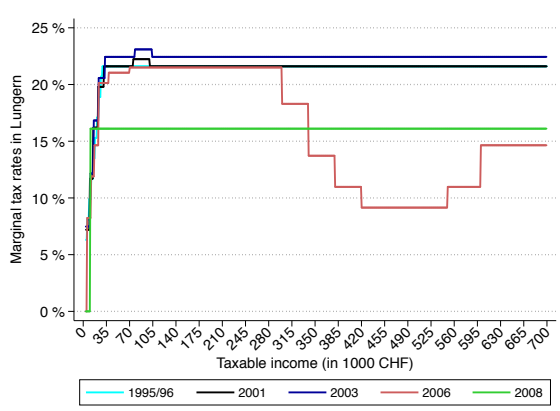

(f) Lungern

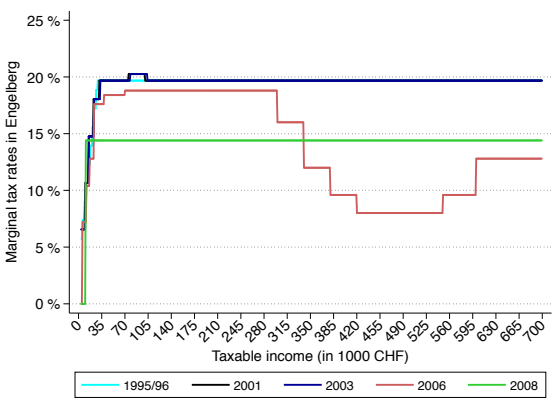

(c) Engelberg

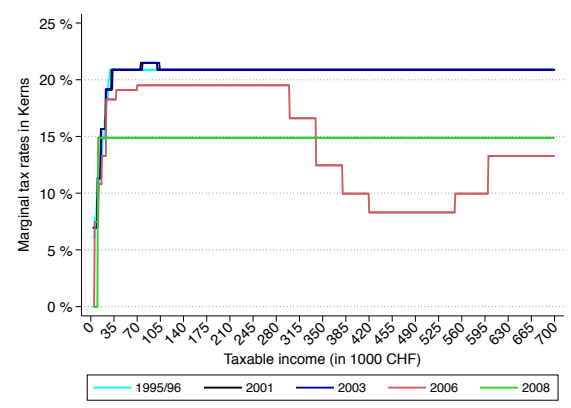

(e) Kerns

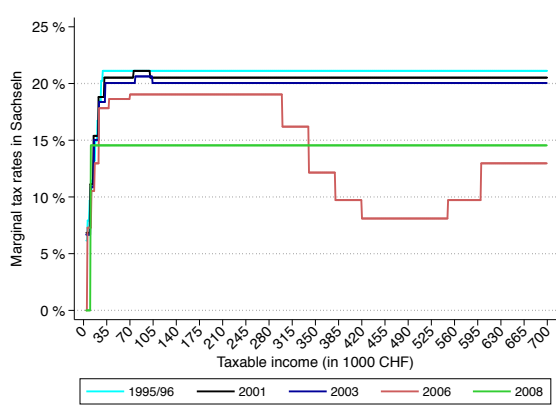

(g) Sachseln

Figure A3: Effective marginal tax rates across municipalities in OW, 1995-2010

Note: Marginal tax rates for taxable income of a single taxpayer, multiplied by the cantonal and the local tax multipliers. Own calculations. 


\section{Appendix B Additional Tables and Figures}

\section{B.1 Additional Tables}

Table B3: DiD Estimates of log share of rich in the canton, corrected for movers

\begin{tabular}{|c|c|c|c|c|}
\hline & $\begin{array}{c}(1) \\
\text { Baseline }\end{array}$ & $\begin{array}{c}(2) \\
\text { Canton } \\
\text { trend }\end{array}$ & $\begin{array}{l}(3) \\
\text { Year } \\
\text { FE }\end{array}$ & $\begin{array}{c}(4) \\
\text { Municipality } \\
\text { FE }\end{array}$ \\
\hline & \multicolumn{4}{|c|}{ Panel A: Lucerne } \\
\hline DiD & $\begin{array}{c}0.333^{*} \\
(0.169)\end{array}$ & $\begin{array}{c}0.413^{* * *} \\
(0.137)\end{array}$ & $\begin{array}{l}0.332^{*} \\
(0.168)\end{array}$ & $\begin{array}{c}0.208^{*} \\
(0.107)\end{array}$ \\
\hline Canton-specific trend & No & Yes & No & No \\
\hline Year FE & No & No & Yes & Yes \\
\hline Municipality FE & No & No & No & Yes \\
\hline Observations & 1,419 & 1,419 & 1,419 & 1,419 \\
\hline R-squared & 0.017 & 0.018 & 0.027 & 0.085 \\
\hline \multirow[t]{2}{*}{ No. of clusters } & 110 & 110 & 110 & 110 \\
\hline & \multicolumn{4}{|c|}{ Panel B: Nidwalden } \\
\hline DiD & $\begin{array}{c}0.295 \\
(0.181)\end{array}$ & $\begin{array}{l}0.321^{*} \\
(0.170)\end{array}$ & $\begin{array}{c}0.289 \\
(0.178)\end{array}$ & $\begin{array}{c}0.261 \\
(0.165)\end{array}$ \\
\hline Canton-specific trend & No & Yes & No & No \\
\hline Year FE & No & No & Yes & Yes \\
\hline Municipality FE & No & No & No & Yes \\
\hline Observations & 291 & 291 & 291 & 291 \\
\hline R-squared & 0.123 & 0.125 & 0.136 & 0.174 \\
\hline No. of clusters & 18 & 18 & 18 & 18 \\
\hline $\mathrm{F}$ & 4.849 & 9.342 & . & 9.619 \\
\hline
\end{tabular}

$* * * \mathrm{p}<0.01, * * \mathrm{p}<0.05, * \mathrm{p}<0.1$

Note: In Models (1)-(3), standard errors are clustered at the municipality level, in Model (4) robust standard errors are reported. The shares of rich taxpayers are corrected by the number of taxpayers moving from Nidwalden, or Lucerne, respectively, to Obwalden after 2005. The number of taxpayers who moved to Obwlden after 2005, as identified in the personal income and wealth tax data from the Cantonal Tax Administration of Obwladen, was subtracted from the municipality of destination in Obwalden and added back to the municipality of origin in Nidwalden or Lucerne, respectively. All regressions include a constant, a post-treatment dummy $(t>2005)$, and a treatment group dummy. DiD denotes the interaction of the post-treatment with the treatment group dummy, hence the DiD estimator.

Source: Individual federal income tax data, ESTV Bern. 
Table B1: DiD Regressions of net income per taxpayer, detailed results canton Lucerne

\begin{tabular}{|c|c|c|c|c|c|}
\hline & $\begin{array}{c}(1) \\
\text { Baseline }\end{array}$ & $\begin{array}{c}(2) \\
\text { Canton } \\
\text { trend }\end{array}$ & $\begin{array}{c}(3) \\
\text { Municip. } \\
\text { FE }\end{array}$ & $\begin{array}{c}(4) \\
\text { Sample: } \\
<300 \mathrm{~K}\end{array}$ & $\begin{array}{c}(5) \\
\text { Sample: } \\
>300 K\end{array}$ \\
\hline DiD & $\begin{array}{c}0.051 \\
(0.070)\end{array}$ & $\begin{array}{c}0.145^{* * *} \\
(0.055)\end{array}$ & $\begin{array}{c}0.036 \\
(0.057)\end{array}$ & $\begin{array}{l}-0.005 \\
(0.012)\end{array}$ & $\begin{array}{l}0.129^{*} \\
(0.067)\end{array}$ \\
\hline Treated & $\begin{array}{c}0.054 \\
(0.062)\end{array}$ & $\begin{array}{c}21.366^{* * *} \\
(3.745)\end{array}$ & $\begin{array}{c}0.377^{* * *} \\
(0.017)\end{array}$ & $\begin{array}{c}0.216^{* * *} \\
(0.004)\end{array}$ & $\begin{array}{c}0.583^{* * *} * \\
(0.057)\end{array}$ \\
\hline Period $t>2005$ & $\begin{array}{c}0.079^{* * *} \\
(0.013)\end{array}$ & $\begin{array}{c}0.081^{* * *} \\
(0.011)\end{array}$ & $\begin{array}{c}0.131^{* * *} \\
(0.021)\end{array}$ & $\begin{array}{c}-0.020^{* *} \\
(0.010)\end{array}$ & $\begin{array}{c}0.007 \\
(0.044)\end{array}$ \\
\hline Non-working & & $\begin{array}{c}-0.600 * * * \\
(0.034)\end{array}$ & $\begin{array}{c}-0.000^{* * *} \\
(0.000)\end{array}$ & $\begin{array}{c}0.051^{* * *} \\
(0.007)\end{array}$ & $\begin{array}{c}0.036 \\
(0.039)\end{array}$ \\
\hline Retiree & & $\begin{array}{c}-0.277^{* * *} \\
(0.018)\end{array}$ & $\begin{array}{c}-0.677^{* * *} \\
(0.029)\end{array}$ & $\begin{array}{l}-0.009 \\
(0.009)\end{array}$ & $\begin{array}{c}0.063 \\
(0.041)\end{array}$ \\
\hline Self-employed & & $\begin{array}{c}0.075^{* * *} \\
(0.012)\end{array}$ & $\begin{array}{c}-0.303^{* * *} \\
(0.015)\end{array}$ & $\begin{array}{l}-0.006 \\
(0.010)\end{array}$ & $\begin{array}{c}0.027 \\
(0.026)\end{array}$ \\
\hline Married & & $\begin{array}{c}0.594^{* * *} \\
(0.012)\end{array}$ & $\begin{array}{c}0.052^{* * *} \\
(0.011)\end{array}$ & $\begin{array}{c}0.670^{* * *} \\
(0.013)\end{array}$ & $\begin{array}{c}0.066 \\
(0.043)\end{array}$ \\
\hline Single parents & & $\begin{array}{c}0.430 * * * \\
(0.015)\end{array}$ & $\begin{array}{c}0.585^{* * *} \\
(0.012)\end{array}$ & $\begin{array}{c}0.446^{* * *} \\
(0.015)\end{array}$ & $\begin{array}{l}-0.040 \\
(0.097)\end{array}$ \\
\hline Married with children & & $\begin{array}{c}0.759 * * * \\
(0.011)\end{array}$ & $\begin{array}{c}0.395^{* * *} \\
(0.018)\end{array}$ & $\begin{array}{c}0.835^{* * *} \\
(0.010)\end{array}$ & $\begin{array}{c}-0.033 \\
(0.049)\end{array}$ \\
\hline \# taxpayers in cell & & $\begin{array}{c}0.000^{* * *} \\
(0.000)\end{array}$ & $\begin{array}{c}0.754^{* * *} \\
(0.011)\end{array}$ & $\begin{array}{c}0.000^{* * *} \\
(0.000)\end{array}$ & $\begin{array}{l}-0.000 \\
(0.001)\end{array}$ \\
\hline Constant & $\begin{array}{c}4.140^{* * *} \\
(0.021)\end{array}$ & $\begin{array}{c}3.628 * * * \\
(0.020)\end{array}$ & $\begin{array}{c}3.427^{* * *} \\
(0.017)\end{array}$ & $\begin{array}{c}3.467^{* * *} \\
(0.012)\end{array}$ & $\begin{array}{c}6.055 * * * \\
(0.057)\end{array}$ \\
\hline Canton-specific trend & No & Yes & No & No & No \\
\hline Time FE & No & No & Yes & Yes & Yes \\
\hline Municipality FE & No & No & Yes & Yes & Yes \\
\hline Controls & No & Yes & Yes & Yes & Yes \\
\hline Observations & 1,748 & 46,001 & 46,001 & 7,193 & 3,644 \\
\hline R-squared & 0.025 & 0.227 & 0.288 & 0.868 & 0.245 \\
\hline No. of clusters & 115 & 115 & 115 & 115 & 110 \\
\hline
\end{tabular}

$* * * \mathrm{p}<0.01, * * \mathrm{p}<0.05, * \mathrm{p}<0.1$

Note: Standard errors clustered at the municipality level. Observations are municipality-year cells. In Columns 2-5 cells are further split into different binary characteristics of the taxpayers, namely: married, single parents, married with children (with single taxpayers with no dependents being the reference category), and self-employed, non-working, retiree (with employees being the reference category). By splitting up the municipality-year cells into these categories, the number of observations increases. Models (2)-(5) further control for cell size. Source: Individual federal income tax data, ESTV Bern. 
Table B2: DiD Regressions of net income per taxpayer, detailed results canton Nidwalden

\begin{tabular}{|c|c|c|c|c|c|}
\hline & $\begin{array}{c}(1) \\
\text { Baseline }\end{array}$ & $\begin{array}{c}(2) \\
\text { Canton } \\
\text { trend }\end{array}$ & $\begin{array}{c}(3) \\
\text { Municip. } \\
\text { FE }\end{array}$ & $\begin{array}{c}(4) \\
\text { Sample: } \\
<300 \mathrm{~K}\end{array}$ & $\begin{array}{c}(5) \\
\text { Sample: } \\
>300 K\end{array}$ \\
\hline DiD & $\begin{array}{c}0.156^{*} \\
(0.081)\end{array}$ & $\begin{array}{c}0.153^{* *} \\
(0.060)\end{array}$ & $\begin{array}{c}0.003 \\
(0.065)\end{array}$ & $\begin{array}{l}-0.008 \\
(0.014)\end{array}$ & $\begin{array}{c}0.234^{* *} \\
(0.088)\end{array}$ \\
\hline Treated & $\begin{array}{c}-0.316^{* *} \\
(0.125)\end{array}$ & $\begin{array}{c}28.011^{* * *} \\
(8.440)\end{array}$ & $\begin{array}{c}0.172^{* * *} \\
(0.019)\end{array}$ & $\begin{array}{c}0.115^{* * *} \\
(0.009)\end{array}$ & $\begin{array}{c}0.170 * * * \\
(0.043)\end{array}$ \\
\hline Period $t>2005$ & $\begin{array}{c}-0.026 \\
(0.039)\end{array}$ & $\begin{array}{c}0.069^{* * *} \\
(0.023)\end{array}$ & $\begin{array}{c}0.132^{* *} \\
(0.052)\end{array}$ & $\begin{array}{l}-0.015 \\
(0.015)\end{array}$ & $\begin{array}{c}-0.032 \\
(0.099)\end{array}$ \\
\hline Non-working & & $\begin{array}{c}-0.652^{* * *} \\
(0.087)\end{array}$ & $\begin{array}{c}-0.000^{* * *} \\
(0.000)\end{array}$ & $\begin{array}{c}0.077^{* * *} \\
(0.012)\end{array}$ & $\begin{array}{c}0.034 \\
(0.131)\end{array}$ \\
\hline Retiree & & $\begin{array}{c}-0.164^{* * *} \\
(0.027)\end{array}$ & $\begin{array}{c}-0.716^{* * *} \\
(0.080)\end{array}$ & $\begin{array}{l}-0.021 \\
(0.015)\end{array}$ & $\begin{array}{c}0.092 \\
(0.090)\end{array}$ \\
\hline Self-employed & & $\begin{array}{c}-0.073^{*} \\
(0.042)\end{array}$ & $\begin{array}{c}-0.212^{* * *} \\
(0.027)\end{array}$ & $\begin{array}{c}0.034 \\
(0.021)\end{array}$ & $\begin{array}{c}0.020 \\
(0.050)\end{array}$ \\
\hline Married & & $\begin{array}{c}0.524^{* * *} \\
(0.040)\end{array}$ & $\begin{array}{c}-0.110^{* *} \\
(0.043)\end{array}$ & $\begin{array}{c}0.621^{* * *} \\
(0.035)\end{array}$ & $\begin{array}{c}-0.068 \\
(0.107)\end{array}$ \\
\hline Single parents & & $\begin{array}{c}0.293^{* * *} \\
(0.057)\end{array}$ & $\begin{array}{c}0.512^{* * *} \\
(0.040)\end{array}$ & $\begin{array}{c}0.337^{* * *} \\
(0.025)\end{array}$ & $\begin{array}{c}-0.193 \\
(0.202)\end{array}$ \\
\hline Married with children & & $\begin{array}{c}0.588^{* * * *} \\
(0.040)\end{array}$ & $\begin{array}{c}0.260 * * * \\
(0.060)\end{array}$ & $\begin{array}{c}0.718^{* * *} \\
(0.019)\end{array}$ & $\begin{array}{c}-0.231 \\
(0.139)\end{array}$ \\
\hline \# taxpayers in cell & & $\begin{array}{l}-0.000 \\
(0.000)\end{array}$ & $\begin{array}{c}0.572^{* * *} \\
(0.040)\end{array}$ & $\begin{array}{l}-0.000 \\
(0.000)\end{array}$ & $\begin{array}{c}-0.006 \\
(0.004)\end{array}$ \\
\hline Constant & $\begin{array}{c}4.510^{* * *} \\
(0.109)\end{array}$ & $\begin{array}{l}-4.743 \\
(7.406)\end{array}$ & $\begin{array}{c}3.601^{* * *} \\
(0.036)\end{array}$ & $\begin{array}{c}3.609^{* * *} \\
(0.029)\end{array}$ & $\begin{array}{c}6.035^{* * *} \\
(0.154)\end{array}$ \\
\hline Canton-specific trend & No & Yes & No & No & No \\
\hline Time FE & No & No & Yes & Yes & Yes \\
\hline Municipality FE & No & No & Yes & Yes & Yes \\
\hline Controls & No & Yes & Yes & Yes & Yes \\
\hline Observations & 288 & 10,264 & 10,264 & 1,203 & 1,002 \\
\hline R-squared & 0.121 & 0.166 & 0.253 & 0.926 & 0.303 \\
\hline No. of clusters & 18 & 18 & 18 & 18 & 18 \\
\hline
\end{tabular}

$* * * \mathrm{p}<0.01,{ }^{* *} \mathrm{p}<0.05,{ }^{*} \mathrm{p}<0.1$

Note: Standard errors clustered at the municipality level. Observations are municipality-year cells. In Columns $2-5$ cells are further split into different binary characteristics of the taxpayers, namely: married, single parents, married with children (with single taxpayers with no dependents being the reference category), and self-employed, non-working, retiree (with employees being the reference category). By splitting up the municipality-year cells into these categories, the number of observations increases. Models (2)-(5) further control for cell size. Source: Individual federal income tax data, ESTV Bern. 
Table B4: Origin of in-comers before and after the 2006 reform (in \%)

\begin{tabular}{|c|c|c|c|c|c|c|}
\hline \multirow[b]{2}{*}{ Origin } & \multicolumn{2}{|c|}{ Treatment } & \multicolumn{2}{|c|}{ Control } & \multicolumn{2}{|c|}{ Total } \\
\hline & $\begin{array}{c}\text { before } 2006 \\
\%\end{array}$ & $\begin{array}{c}\text { after } 2006 \\
\%\end{array}$ & $\begin{array}{c}\text { before } 2006 \\
\%\end{array}$ & $\begin{array}{c}\text { after } 2006 \\
\%\end{array}$ & $\begin{array}{c}\text { before } 2006 \\
\%\end{array}$ & $\begin{array}{c}\text { after } 2006 \\
\%\end{array}$ \\
\hline $\mathrm{ZH}$ & 11.63 & 15.17 & 21.62 & 10.99 & 8.33 & 9.35 \\
\hline $\mathrm{BE}$ & 2.33 & 4.83 & 2.70 & 4.40 & 5.55 & 5.81 \\
\hline LU & 23.26 & 19.31 & 18.92 & 27.47 & 25.93 & 24.99 \\
\hline UR & 2.33 & & & & 1.78 & 1.35 \\
\hline $\mathrm{SZ}$ & & 2.07 & & 1.10 & 3.14 & 3.16 \\
\hline NW & 13.95 & 7.59 & 8.11 & 10.99 & 13.64 & 14.92 \\
\hline GL & & & & & 0.12 & 0.17 \\
\hline $\mathrm{ZG}$ & 11.63 & 7.59 & 5.41 & 5.49 & 4.35 & 4.12 \\
\hline $\mathrm{FR}$ & & & & 1.10 & 0.42 & 0.27 \\
\hline $\mathrm{SO}$ & & & 5.41 & 3.30 & 2.05 & 1.64 \\
\hline $\mathrm{BS}$ & 4.65 & 1.38 & 5.41 & 3.30 & 1.51 & 1.33 \\
\hline BL & 2.33 & 4.83 & 5.41 & 6.59 & 3.08 & 2.77 \\
\hline $\mathrm{SH}$ & & & & & 0.30 & 0.36 \\
\hline $\mathrm{AR}$ & & 0.69 & & & 0.18 & 0.24 \\
\hline $\mathrm{AI}$ & & 0.69 & & & 0.03 & 0.17 \\
\hline SG & 2.33 & & 2.70 & & 1.99 & 1.69 \\
\hline GR & & 0.69 & & 2.20 & 1.42 & 1.47 \\
\hline $\mathrm{AG}$ & 16.28 & 11.03 & 8.11 & 6.59 & 6.55 & 6.80 \\
\hline TG & & & & & 0.81 & 0.80 \\
\hline $\mathrm{TI}$ & 2.33 & 2.07 & 2.70 & 1.10 & 0.66 & 0.92 \\
\hline VD & & 2.76 & & & 0.30 & 0.77 \\
\hline VS & & & & & 0.97 & 0.67 \\
\hline $\mathrm{NE}$ & & 0.69 & & & 0.09 & 0.27 \\
\hline GE & & 2.07 & 2.70 & & 0.24 & 0.31 \\
\hline JU & & 0.69 & & & 0.03 & 0.10 \\
\hline Abroad & 6.98 & 12.41 & 10.81 & 12.09 & 14.13 & 13.62 \\
\hline Unknown & & 3.45 & & 3.30 & 2.35 & 1.95 \\
\hline Total & 100.00 & 100.00 & 100.00 & 100.00 & 100.00 & 100.00 \\
\hline
\end{tabular}

Note: Treatment group: taxpayers with rate-determining income $>$ CHF 300,000. Control group defined as those having rate-determining income of $180,000-240,000 \mathrm{CHF}$, i.e, $60-80 \%$ of the regressive threshold.

Source: Personal income and wealth tax data Obwalden, 2001-2010. 
Table B5: Detailed results: DiD of stock of taxpayers in OW, control group 60-80\%

\begin{tabular}{|c|c|c|c|c|c|c|c|c|}
\hline & (1) & $(2)$ & $(3)$ & (4) & (5) & (6) & $(7)$ & (8) \\
\hline & \multicolumn{6}{|c|}{$2001-2007$} & \multicolumn{2}{|c|}{$2001-2010$} \\
\hline & $\begin{array}{l}\text { Reduced } \\
\text { (level) }\end{array}$ & $\begin{array}{c}\text { Reduced } \\
\quad(\log )\end{array}$ & $\begin{array}{c}2 \mathrm{SLS} \\
(\log )\end{array}$ & $\begin{array}{c}2 \mathrm{SLS} \\
(\log )\end{array}$ & $\begin{array}{l}\text { OLS } \\
(\log )\end{array}$ & $\begin{array}{l}\text { OLS } \\
(\log )\end{array}$ & $\begin{array}{c}2 \text { SLS } \\
(\log )\end{array}$ & $\begin{array}{c}2 \mathrm{SLS} \\
(\log )\end{array}$ \\
\hline DiD & $\begin{array}{c}36.80^{*} \\
(15.29)\end{array}$ & $\begin{array}{c}0.06 \\
(0.05)\end{array}$ & & & & & & \\
\hline$\varepsilon_{\tau}$ & & & $\begin{array}{c}0.76^{* *} \\
(0.35)\end{array}$ & & $\begin{array}{c}0.75 \\
(0.59)\end{array}$ & & $\begin{array}{l}0.72^{*} \\
(0.42)\end{array}$ & \\
\hline$\varepsilon_{\bar{\tau}}$ & & & & $\begin{array}{c}1.94^{* *} \\
(0.88)\end{array}$ & & $\begin{array}{c}1.95 \\
(1.48)\end{array}$ & & $\begin{array}{l}1.94^{*} \\
(1.14)\end{array}$ \\
\hline Treatment & $\begin{array}{c}53.20^{* * *} \\
(8.17)\end{array}$ & $\begin{array}{c}0.18^{* * *} \\
(0.03)\end{array}$ & $\begin{array}{c}0.18^{* * *} \\
(0.02)\end{array}$ & $\begin{array}{c}0.20 * * * \\
(0.01)\end{array}$ & $\begin{array}{c}0.18^{* * *} \\
(0.03)\end{array}$ & $\begin{array}{c}0.20 * * * \\
(0.02)\end{array}$ & $\begin{array}{c}0.18^{* * *} \\
(0.02)\end{array}$ & $\begin{array}{c}0.19^{* * *} \\
(0.01)\end{array}$ \\
\hline year $=2002$ & $\begin{array}{c}-1.00 \\
(12.92)\end{array}$ & $\begin{array}{c}0.00 \\
(0.04)\end{array}$ & $\begin{array}{c}0.00 \\
(0.02)\end{array}$ & $\begin{array}{c}0.00 \\
(0.02)\end{array}$ & $\begin{array}{c}0.00 \\
(0.04)\end{array}$ & $\begin{array}{c}0.00 \\
(0.04)\end{array}$ & $\begin{array}{c}0.00 \\
(0.03)\end{array}$ & $\begin{array}{c}0.00 \\
(0.03)\end{array}$ \\
\hline year $=2003$ & $\begin{array}{c}7.00 \\
(12.92)\end{array}$ & $\begin{array}{c}0.03 \\
(0.04)\end{array}$ & $\begin{array}{c}0.03 \\
(0.02)\end{array}$ & $\begin{array}{c}0.02 \\
(0.02)\end{array}$ & $\begin{array}{c}0.03 \\
(0.04)\end{array}$ & $\begin{array}{c}0.02 \\
(0.04)\end{array}$ & $\begin{array}{c}0.03 \\
(0.03)\end{array}$ & $\begin{array}{c}0.02 \\
(0.03)\end{array}$ \\
\hline year $=2004$ & $\begin{array}{c}13.50 \\
(12.92)\end{array}$ & $\begin{array}{c}0.05 \\
(0.04)\end{array}$ & $\begin{array}{c}0.05^{* *} \\
(0.02)\end{array}$ & $\begin{array}{c}0.05^{* *} \\
(0.02)\end{array}$ & $\begin{array}{c}0.05 \\
(0.04)\end{array}$ & $\begin{array}{c}0.05 \\
(0.04)\end{array}$ & $\begin{array}{c}0.05 \\
(0.03)\end{array}$ & $\begin{array}{c}0.05 \\
(0.03)\end{array}$ \\
\hline year $=2005$ & $\begin{array}{c}17.50 \\
(12.92)\end{array}$ & $\begin{array}{c}0.06 \\
(0.04)\end{array}$ & $\begin{array}{c}0.06^{* * *} \\
(0.02)\end{array}$ & $\begin{array}{c}0.06^{* *} \\
(0.02)\end{array}$ & $\begin{array}{c}0.06 \\
(0.04)\end{array}$ & $\begin{array}{c}0.06 \\
(0.04)\end{array}$ & $\begin{array}{c}0.06^{* *} \\
(0.03)\end{array}$ & $\begin{array}{l}0.06^{*} \\
(0.03)\end{array}$ \\
\hline year $=2006$ & $\begin{array}{l}51.10^{* *} \\
(15.01)\end{array}$ & $\begin{array}{c}0.19^{* * *} \\
(0.05)\end{array}$ & $\begin{array}{c}0.18^{* * *} \\
(0.03)\end{array}$ & $\begin{array}{c}0.16^{* * *} \\
(0.04)\end{array}$ & $\begin{array}{c}0.18^{* *} \\
(0.05)\end{array}$ & $\begin{array}{l}0.16^{* *} \\
(0.06)\end{array}$ & $\begin{array}{c}0.18^{* * *} \\
(0.04)\end{array}$ & $\begin{array}{c}0.16^{* * *} \\
(0.05)\end{array}$ \\
\hline year $=2007$ & $\begin{array}{c}79.10^{* * *} \\
(15.01)\end{array}$ & $\begin{array}{c}0.26^{* * *} \\
(0.05)\end{array}$ & $\begin{array}{c}0.25^{* * *} \\
(0.03)\end{array}$ & $\begin{array}{c}0.23^{* * *} \\
(0.04)\end{array}$ & $\begin{array}{c}0.25^{* * *} \\
(0.05)\end{array}$ & $\begin{array}{l}0.23^{* *} \\
(0.06)\end{array}$ & $\begin{array}{c}0.25^{* * *} \\
(0.04)\end{array}$ & $\begin{array}{c}0.23^{* * *} \\
(0.05)\end{array}$ \\
\hline year $=2008$ & & & & & & & $\begin{array}{c}0.26^{* * *} \\
(0.04)\end{array}$ & $\begin{array}{c}0.20^{* * *} \\
(0.07)\end{array}$ \\
\hline year $=2009$ & & & & & & & $\begin{array}{c}0.32^{* * *} \\
(0.04)\end{array}$ & $\begin{array}{c}0.26^{* * *} \\
(0.07)\end{array}$ \\
\hline year $=2010$ & & & & & & & $\begin{array}{c}0.38^{* * *} \\
(0.04)\end{array}$ & $\begin{array}{c}0.31^{* * *} \\
(0.07)\end{array}$ \\
\hline Constant & $\begin{array}{c}263.40^{* * *} \\
(10.01)\end{array}$ & $\begin{array}{c}5.57^{* * *} \\
(0.03)\end{array}$ & $\begin{array}{c}5.74^{* * *} \\
(0.08)\end{array}$ & $\begin{array}{c}5.97 * * * \\
(0.19)\end{array}$ & $\begin{array}{c}5.74^{* * *} \\
(0.14)\end{array}$ & $\begin{array}{c}5.98 * * * \\
(0.31)\end{array}$ & $\begin{array}{c}5.73^{* * *} \\
(0.10)\end{array}$ & $\begin{array}{c}5.98^{* * *} \\
(0.24)\end{array}$ \\
\hline Observations & 14 & 14 & 14 & 14 & 14 & 14 & 20 & 20 \\
\hline R-squared & 0.98 & 0.97 & 0.97 & 0.97 & 0.97 & 0.97 & 0.97 & 0.97 \\
\hline$\Delta \tau 2006(\% \mathrm{pts})$ & 3.76 & & & & & & 3.76 & \\
\hline$\Delta \tau 2008(\% \mathrm{pts})$ & 1.29 & & & & & & 1.29 & \\
\hline $\mathrm{F}$ & 24.74 & 23.17 & & & 23.03 & 23.36 & & \\
\hline$\chi^{2}$ & & & 515.90 & 523.10 & & & 726.60 & 728.70 \\
\hline Hausman $^{1}$ & & & 0.00 & 0.00 & & & 0.00 & -0.01 \\
\hline $\mathrm{P}$-value & & & 1 & 1 & & & 1 & \\
\hline
\end{tabular}

$* * * \mathrm{p}<0.01, * * \mathrm{p}<0.05, * \mathrm{p}<0.1$. Standard errors in parentheses.

${ }^{1}$ Test statistic of a Hausman exogeneity test comparing OLS and 2SLS models.

Source: Personal income and wealth tax data Obwalden, 2001-2010. 
Table B6: Detailed results: DiD of inflow of taxpayers to OW, control group 60-80\%

\begin{tabular}{|c|c|c|c|c|c|c|c|c|}
\hline & (1) & (2) & (3) & (4) & (5) & (6) & (7) & (8) \\
\hline & \multicolumn{6}{|c|}{ 2001-2007 } & \multicolumn{2}{|c|}{ 2001-2010 } \\
\hline & $\begin{array}{c}\text { Reduced } \\
\text { (level) }\end{array}$ & $\begin{array}{c}\text { Reduced } \\
(\log )\end{array}$ & $\begin{array}{r}2 \text { SLS } \\
(\log ) \\
\end{array}$ & $\begin{array}{l}\text { 2SLS } \\
(\log ) \\
\end{array}$ & $\begin{array}{l}\text { OLS } \\
(\log ) \\
\end{array}$ & $\begin{array}{l}\text { OLS } \\
(\log ) \\
\end{array}$ & $\begin{array}{l}\text { 2SLS } \\
(\log ) \\
\end{array}$ & $\begin{array}{l}\text { 2SLS } \\
(\log ) \\
\end{array}$ \\
\hline DiD & $\begin{array}{l}8.40^{*} \\
(3.76)\end{array}$ & $\begin{array}{c}0.29 \\
(0.30)\end{array}$ & & & & & & \\
\hline$\varepsilon_{\tau}$ & & & $\begin{array}{c}3.74 \\
(2.28)\end{array}$ & & $\begin{array}{c}3.87 \\
(3.79)\end{array}$ & & $\begin{array}{c}2.42 \\
(1.94)\end{array}$ & \\
\hline$\varepsilon_{\bar{\tau}}$ & & & & $\begin{array}{l}7.65^{*} \\
(4.34)\end{array}$ & & $\begin{array}{c}8.95 \\
(6.31)\end{array}$ & & $\begin{array}{c}5.14 \\
(3.84)\end{array}$ \\
\hline Treatment & $\begin{array}{l}1.60 \\
(2.01)\end{array}$ & $\begin{array}{c}0.22 \\
(0.16)\end{array}$ & $\begin{array}{c}0.22^{* *} \\
(0.09)\end{array}$ & $\begin{array}{c}0.26^{* * *} \\
(0.08)\end{array}$ & $\begin{array}{c}0.22 \\
(0.16)\end{array}$ & $\begin{array}{l}0.26^{*} \\
(0.13)\end{array}$ & $\begin{array}{c}0.31^{* * *} \\
(0.07)\end{array}$ & $\begin{array}{c}0.34^{* * *} \\
(0.06)\end{array}$ \\
\hline year $=2002$ & $\begin{array}{c}2.00 \\
(3.18)\end{array}$ & $\begin{array}{c}0.29 \\
(0.25)\end{array}$ & $\begin{array}{l}0.28^{*} \\
(0.15)\end{array}$ & $\begin{array}{c}0.34^{* *} \\
(0.14)\end{array}$ & $\begin{array}{c}0.28 \\
(0.25)\end{array}$ & $\begin{array}{c}0.35 \\
(0.24)\end{array}$ & $\begin{array}{c}0.29^{* *} \\
(0.14)\end{array}$ & $\begin{array}{c}0.32^{* *} \\
(0.14)\end{array}$ \\
\hline year $=2003$ & $\begin{array}{c}4.00 \\
(3.18)\end{array}$ & $\begin{array}{c}0.49 \\
(0.25)\end{array}$ & $\begin{array}{c}0.48^{* * *} \\
(0.15)\end{array}$ & $\begin{array}{c}0.50^{* * * *} \\
(0.14)\end{array}$ & $\begin{array}{c}0.48 \\
(0.25)\end{array}$ & $\begin{array}{l}0.50^{*} \\
(0.23)\end{array}$ & $\begin{array}{c}0.49^{* * *} \\
(0.14)\end{array}$ & $\begin{array}{c}0.49^{* * * *} \\
(0.13)\end{array}$ \\
\hline year $=2004$ & $\begin{array}{c}2.50 \\
(3.18)\end{array}$ & $\begin{array}{c}0.34 \\
(0.25)\end{array}$ & $\begin{array}{c}0.32^{* *} \\
(0.15)\end{array}$ & $\begin{array}{c}0.37^{* * *} \\
(0.14)\end{array}$ & $\begin{array}{c}0.32 \\
(0.25)\end{array}$ & $\begin{array}{c}0.37 \\
(0.23)\end{array}$ & $\begin{array}{c}0.33^{* *} \\
(0.14)\end{array}$ & $\begin{array}{c}0.36^{* * *} \\
(0.13)\end{array}$ \\
\hline year $=2005$ & $\begin{array}{c}0.50 \\
(3.18)\end{array}$ & $\begin{array}{c}0.09 \\
(0.25)\end{array}$ & $\begin{array}{l}0.06 \\
(0.15)\end{array}$ & $\begin{array}{c}0.07 \\
(0.14)\end{array}$ & $\begin{array}{c}0.06 \\
(0.25)\end{array}$ & $\begin{array}{c}0.07 \\
(0.23)\end{array}$ & $\begin{array}{c}0.07 \\
(0.14)\end{array}$ & $\begin{array}{c}0.08 \\
(0.13)\end{array}$ \\
\hline year $=2006$ & $\begin{array}{l}7.80^{*} \\
(3.70)\end{array}$ & $\begin{array}{c}0.89^{* *} \\
(0.29)\end{array}$ & $\begin{array}{c}0.85^{* * *} \\
(0.19)\end{array}$ & $\begin{array}{c}0.82^{* * *} \\
(0.19)\end{array}$ & $\begin{array}{c}0.84^{* *} \\
(0.31)\end{array}$ & $\begin{array}{c}0.78^{* *} \\
(0.29)\end{array}$ & $\begin{array}{c}0.91^{* * *} \\
(0.17)\end{array}$ & $\begin{array}{c}0.89^{* * * *} \\
(0.17)\end{array}$ \\
\hline year $=2007$ & $\begin{array}{l}9.80^{* *} \\
(3.70)\end{array}$ & $\begin{array}{c}0.92^{* *} \\
(0.29)\end{array}$ & $\begin{array}{c}0.85^{* * *} \\
(0.20)\end{array}$ & $\begin{array}{c}0.79^{* * *} \\
(0.21)\end{array}$ & $\begin{array}{c}0.85^{* *} \\
(0.33)\end{array}$ & $\begin{array}{l}0.74^{*} \\
(0.33)\end{array}$ & $\begin{array}{c}0.93^{* * *} \\
(0.18)\end{array}$ & $\begin{array}{c}0.88^{* * *} \\
(0.19)\end{array}$ \\
\hline year $=2008$ & & & & & & & $\begin{array}{c}1.05^{* * *} \\
(0.18)\end{array}$ & $\begin{array}{c}0.94^{* * *} \\
(0.23)\end{array}$ \\
\hline year $=2009$ & & & & & & & $\begin{array}{c}1.27^{* * *} \\
(0.18)\end{array}$ & $\begin{array}{c}1.16^{* * *} \\
(0.24)\end{array}$ \\
\hline year $=2010$ & & & & & & & $\begin{array}{c}1.21^{* * *} \\
(0.18)\end{array}$ & $\begin{array}{c}1.10^{* * *} \\
(0.23)\end{array}$ \\
\hline Constant & $\begin{array}{l}6.20^{*} \\
(2.46)\end{array}$ & $\begin{array}{c}1.80^{* * *} \\
(0.20)\end{array}$ & $\begin{array}{c}2.63^{* * *} \\
(0.54)\end{array}$ & $\begin{array}{c}3.37^{* * *} \\
(0.92)\end{array}$ & $\begin{array}{c}2.66^{* *} \\
(0.91)\end{array}$ & $\begin{array}{c}3.64^{* *} \\
(1.34)\end{array}$ & $\begin{array}{c}2.29 * * * \\
(0.46)\end{array}$ & $\begin{array}{c}2.81^{* * *} \\
(0.81)\end{array}$ \\
\hline Observations & 14 & 14 & 14 & 14 & 14 & 14 & 20 & 20 \\
\hline R-squared & 0.91 & 0.89 & 0.89 & 0.91 & 0.89 & 0.91 & 0.94 & 0.94 \\
\hline$\Delta \tau 2006(\% \mathrm{pts})$ & 4.40 & & & & & & 4.40 & \\
\hline$\Delta \tau 2008$ (\% pts) & 0.16 & & & & & & 0.16 & \\
\hline $\mathrm{F}$ & 6.05 & 5.01 & & & 5.10 & 6.02 & & \\
\hline$\chi^{2}$ & & & 114.00 & 131.20 & & & 309.10 & 336.40 \\
\hline Hausman $^{1}$ & & & 0.00 & -0.08 & & & -0.01 & -0.06 \\
\hline P-value & & & 1 & 1 & & & 1 & 1 \\
\hline
\end{tabular}

*** $\mathrm{p}<0.01,{ }^{* *} \mathrm{p}<0.05,{ }^{*} \mathrm{p}<0.1$. Standard errors in parentheses.

${ }^{1}$ Test statistic of a Hausman exogeneity test comparing OLS and 2SLS models.

Source: Personal income and wealth tax data Obwalden, 2001-2010. 
Table B7: Detailed results: DiD of inflow of taxpayers to OW, control group 55-75\%

\begin{tabular}{|c|c|c|c|c|c|c|c|c|}
\hline & (1) & $(2)$ & $(3)$ & (4) & $(5)$ & (6) & $(7)$ & $(8)$ \\
\hline & \multicolumn{6}{|c|}{$2001-2007$} & \multicolumn{2}{|c|}{$2001-2010$} \\
\hline & $\begin{array}{c}\text { Reduced } \\
\text { (level) }\end{array}$ & $\begin{array}{l}\text { Reduced } \\
\quad(\log )\end{array}$ & $\begin{array}{c}2 \mathrm{SLS} \\
(\log )\end{array}$ & $\begin{array}{c}2 \mathrm{SLS} \\
(\log )\end{array}$ & $\begin{array}{l}\text { OLS } \\
(\log )\end{array}$ & $\begin{array}{l}\text { OLS } \\
(\log )\end{array}$ & $\begin{array}{c}2 \mathrm{SLS} \\
(\log )\end{array}$ & $\begin{array}{c}2 \mathrm{SLS} \\
(\log )\end{array}$ \\
\hline DiD & $\begin{array}{c}9.60^{* *} \\
(3.02)\end{array}$ & $\begin{array}{l}0.45^{*} \\
(0.21)\end{array}$ & & & & & & \\
\hline$\varepsilon_{\tau}$ & & & $\begin{array}{c}5.64^{* * *} \\
(1.51)\end{array}$ & & $\begin{array}{l}5.99 * \\
(2.51)\end{array}$ & & $\begin{array}{c}4.25^{* * *} \\
(1.49)\end{array}$ & \\
\hline$\varepsilon_{\bar{\tau}}$ & & & & $\begin{array}{c}11.76^{* * *} \\
(1.88)\end{array}$ & & $\begin{array}{c}13.39^{* * *} \\
(2.57)\end{array}$ & & $\begin{array}{c}9.69^{* * *} \\
(2.49)\end{array}$ \\
\hline Treatment & $\begin{array}{c}0.40 \\
(1.61)\end{array}$ & $\begin{array}{c}0.05 \\
(0.11)\end{array}$ & $\begin{array}{c}0.07 \\
(0.06)\end{array}$ & $\begin{array}{c}0.15^{* * *} \\
(0.03)\end{array}$ & $\begin{array}{c}0.06 \\
(0.10)\end{array}$ & $\begin{array}{c}0.14^{* *} \\
(0.05)\end{array}$ & $\begin{array}{c}0.17^{* * *} \\
(0.05)\end{array}$ & $\begin{array}{c}0.22^{* * *} \\
(0.04)\end{array}$ \\
\hline year $=2002$ & $\begin{array}{c}3.00 \\
(2.55)\end{array}$ & $\begin{array}{c}0.36 \\
(0.18)\end{array}$ & $\begin{array}{c}0.36^{* * *} \\
(0.10)\end{array}$ & $\begin{array}{c}0.41^{* * *} \\
(0.06)\end{array}$ & $\begin{array}{l}0.36^{*} \\
(0.17)\end{array}$ & $\begin{array}{c}0.42^{* * *} \\
(0.10)\end{array}$ & $\begin{array}{c}0.36 * * * \\
(0.11)\end{array}$ & $\begin{array}{c}0.40^{* * *} \\
(0.08)\end{array}$ \\
\hline year $=2003$ & $\begin{array}{c}3.50 \\
(2.55)\end{array}$ & $\begin{array}{l}0.40^{*} \\
(0.18)\end{array}$ & $\begin{array}{c}0.41^{* * *} \\
(0.10)\end{array}$ & $\begin{array}{c}0.40^{* * *} \\
(0.06)\end{array}$ & $\begin{array}{l}0.41^{*} \\
(0.17)\end{array}$ & $\begin{array}{c}0.41^{* * *} \\
(0.10)\end{array}$ & $\begin{array}{c}0.40^{* * *} \\
(0.11)\end{array}$ & $\begin{array}{c}0.40^{* * *} \\
(0.08)\end{array}$ \\
\hline year $=2004$ & $\begin{array}{l}1.00 \\
(2.55)\end{array}$ & $\begin{array}{c}0.14 \\
(0.18)\end{array}$ & $\begin{array}{c}0.13 \\
(0.10)\end{array}$ & $\begin{array}{c}0.17^{* * *} \\
(0.06)\end{array}$ & $\begin{array}{c}0.13 \\
(0.17)\end{array}$ & $\begin{array}{c}0.17 \\
(0.10)\end{array}$ & $\begin{array}{c}0.13 \\
(0.11)\end{array}$ & $\begin{array}{l}0.16^{*} \\
(0.08)\end{array}$ \\
\hline year $=2005$ & $\begin{array}{c}2.00 \\
(2.55)\end{array}$ & $\begin{array}{c}0.26 \\
(0.18)\end{array}$ & $\begin{array}{c}0.24^{* *} \\
(0.10)\end{array}$ & $\begin{array}{c}0.23^{* * *} \\
(0.06)\end{array}$ & $\begin{array}{c}0.23 \\
(0.17)\end{array}$ & $\begin{array}{c}0.22^{*} \\
(0.10)\end{array}$ & $\begin{array}{c}0.24^{* *} \\
(0.11)\end{array}$ & $\begin{array}{c}0.23^{* * *} \\
(0.08)\end{array}$ \\
\hline year $=2006$ & $\begin{array}{l}6.20^{*} \\
(2.97)\end{array}$ & $\begin{array}{c}0.69^{* *} \\
(0.21)\end{array}$ & $\begin{array}{c}0.64^{* * *} \\
(0.12)\end{array}$ & $\begin{array}{c}0.57^{* * *} \\
(0.08)\end{array}$ & $\begin{array}{c}0.62^{* *} \\
(0.21)\end{array}$ & $\begin{array}{c}0.52^{* * *} \\
(0.12)\end{array}$ & $\begin{array}{c}0.71^{* * *} \\
(0.13)\end{array}$ & $\begin{array}{c}0.63^{* * *} \\
(0.11)\end{array}$ \\
\hline year $=2007$ & $\begin{array}{c}9.20^{* *} \\
(2.97)\end{array}$ & $\begin{array}{c}0.79^{* *} \\
(0.21)\end{array}$ & $\begin{array}{c}0.71^{* * *} \\
(0.13)\end{array}$ & $\begin{array}{c}0.57^{* * *} \\
(0.09)\end{array}$ & $\begin{array}{c}0.70^{* *} \\
(0.21)\end{array}$ & $\begin{array}{c}0.51^{* *} \\
(0.14)\end{array}$ & $\begin{array}{c}0.79 * * * \\
(0.13)\end{array}$ & $\begin{array}{c}0.65^{* * *} \\
(0.12)\end{array}$ \\
\hline year $=2008$ & & & & & & & $\begin{array}{c}0.90^{* * *} \\
(0.14)\end{array}$ & $\begin{array}{c}0.67^{* * *} \\
(0.15)\end{array}$ \\
\hline year $=2009$ & & & & & & & $\begin{array}{c}1.18^{* * *} \\
(0.14)\end{array}$ & $\begin{array}{c}0.94^{* * *} \\
(0.15)\end{array}$ \\
\hline year $=2010$ & & & & & & & $\begin{array}{c}1.06^{* * *} \\
(0.14)\end{array}$ & $\begin{array}{c}0.84^{* * *} \\
(0.15)\end{array}$ \\
\hline Constant & $\begin{array}{c}7.30^{* *} \\
(1.98)\end{array}$ & $\begin{array}{c}1.97^{* * *} \\
(0.14)\end{array}$ & $\begin{array}{c}3.20 * * * \\
(0.36)\end{array}$ & $\begin{array}{c}4.38^{* * *} \\
(0.40)\end{array}$ & $\begin{array}{c}3.28^{* * *} \\
(0.59)\end{array}$ & $\begin{array}{c}4.72^{* * *} \\
(0.55)\end{array}$ & $\begin{array}{c}2.85 * * * \\
(0.35)\end{array}$ & $\begin{array}{c}3.91^{* * *} \\
(0.52)\end{array}$ \\
\hline Observations & 14 & 14 & 14 & 14 & 14 & 14 & 20 & 20 \\
\hline R-squared & 0.93 & 0.93 & 0.93 & 0.98 & 0.93 & 0.98 & 0.96 & 0.97 \\
\hline$\Delta \tau 2006(\% \mathrm{pts})$ & 4.40 & & & & & & & \\
\hline$\Delta \tau 2008(\% \mathrm{pts})$ & 0.16 & & & & & & & \\
\hline $\mathrm{F}$ & 8.57 & 7.79 & & & 8.90 & 27.99 & & \\
\hline$\chi^{2}$ & & & 196.7 & 549.5 & & & 456.8 & 755.3 \\
\hline Hausman $^{1}$ & & & -0.03 & -0.86 & & & -0.01 & -0.96 \\
\hline $\mathrm{P}$-value & & & 1 & 1 & & & 1 & 1 \\
\hline
\end{tabular}

$* * * \mathrm{p}<0.01, * * \mathrm{p}<0.05, * \mathrm{p}<0.1$. Standard errors in parentheses.

${ }^{1}$ Test statistic of a Hausman exogeneity test comparing OLS and 2SLS models.

Source: Personal income and wealth tax data Obwalden, 2001-2010. 
Table B8: Difference-in-Differences in shares of taxpayers

\begin{tabular}{cccccc}
\hline$(1)$ & $(2)$ & $(3)$ & $(4)$ & $(5)$ & $(6)$ \\
Reduced & Reduced & 2SLS & 2SLS & 2SLS & 2SLS \\
$(\operatorname{level})$ & $(\log )$ & $(\log )$ & $(\log )$ & $(\log )$ & $(\log )$ \\
\hline
\end{tabular}

Panel A

Stock of taxpayers (all residents and in-comers)

$$
\begin{aligned}
& \text { Control group } \\
& \text { DiD } \\
& \varepsilon_{\tau}(2006-07) \\
& \varepsilon_{\bar{\tau}}(2006-07)
\end{aligned}
$$

Observations

R-squared

F

$\chi^{2}$
$60-80 \%$

0.061

$0.001^{*}$

$(0.047)$

$(0.001)$

.

$0.762^{* *}$
$(0.350)$

$1.937^{* *}$

$(0.885)$
$60-95 \%$

$0.926^{* * *}$

(0.350)

$2.371^{* * *}$

(0.885)

$\begin{array}{cccccc}14 & 14 & 14 & 14 & 14 & 14 \\ 0.97 & 0.97 & 0.97 & 0.97 & 0.96 & 0.93 \\ 20.55 & 19.52 & & & & \\ & & 434.7 & 440.7 & 369.1 & 179.0\end{array}$

\section{Panel B}

Flow of taxpayers (in-comers only)

Control group

$60-80 \%$

$55-75 \%$

$$
\begin{aligned}
& \mathrm{DiD} \\
& \varepsilon_{\tau}(2006-07) \\
& \varepsilon_{\bar{\tau}}(2006-07)
\end{aligned}
$$

$\begin{array}{cc}0.000^{*} & 0.290 \\ (0.000) & (0.298)\end{array}$

3.739

(2.275)

\begin{tabular}{ccc}
\multicolumn{3}{c}{$5.625^{* * *}$} \\
& $(1.507)$ & \\
$7.643^{*}$ & & $11.726^{* * *}$ \\
$(4.335)$ & & $(1.888)$ \\
& & 14 \\
14 & 14 & 0.97 \\
0.90 & 0.93 & 500.9 \\
122.2 & 180.7 & \\
\hline
\end{tabular}

$* * * \mathrm{p}<0.01, * * \mathrm{p}<0.05, * \mathrm{p}<0.1$. Standard errors in parentheses.

Note: The dependent variable is the share of taxpayers (Panel A) or in-comers (Panel B) in the treatment and control group, respectively, as fraction of total population in the canton in a given year. All regressions include a constant, a treatment dummy, and year dummies. Source: Personal income and wealth tax data Obwalden, 2001-2010. 
Table B9: ETI estimation sample descriptives

\begin{tabular}{lcc}
\hline Variable & Mean & SD \\
Log change in NTR (lagged) & 0.015 & 0.060 \\
& & \\
Rate-determining income (in 1,000 CHF) & 498 & 1,418 \\
Taxable income (in 1,000 CHF) & 197 & 974 \\
Rate-determining wealth (in 1,000 CHF) & 3,120 & 13,897 \\
Taxable wealth (in 1,000 CHF) & 8,092 & 25,877 \\
& & \\
Log change in taxable income & 0.066 & 0.953 \\
Log of lagged taxable base-year income ( $\Delta=3)$ & 10.630 & 2.118 \\
Log change in rate-determining income & -0.035 & 0.895 \\
Log of lagged rate-determining base-year income $(\Delta=3)$ & 12.490 & 1.061 \\
& & \\
Married & 0.709 & 0.454 \\
Double earners & 0.409 & 0.492 \\
Children (dummy) & 0.388 & 0.487 \\
Self employed & 0.204 & 0.403 \\
Retiree & 0.104 & 0.306 \\
Age & 57.00 & 12.66 \\
Engelberg & 0.428 & 0.495 \\
Giswil & 0.036 & 0.185 \\
Kerns & 0.076 & 0.264 \\
Sangern & 0.031 & 0.172 \\
Sarnen & 0.086 & 0.280 \\
Observations & 0.264 & 0.441 \\
\hline \hline & 5,381 & \\
\hline
\end{tabular}

Source: Personal income and wealth tax data Obwalden, 2001-2010. 


\section{B.2 Additional Figures}

Average Income Tax on 500,000 CHF Gross Income, 2005

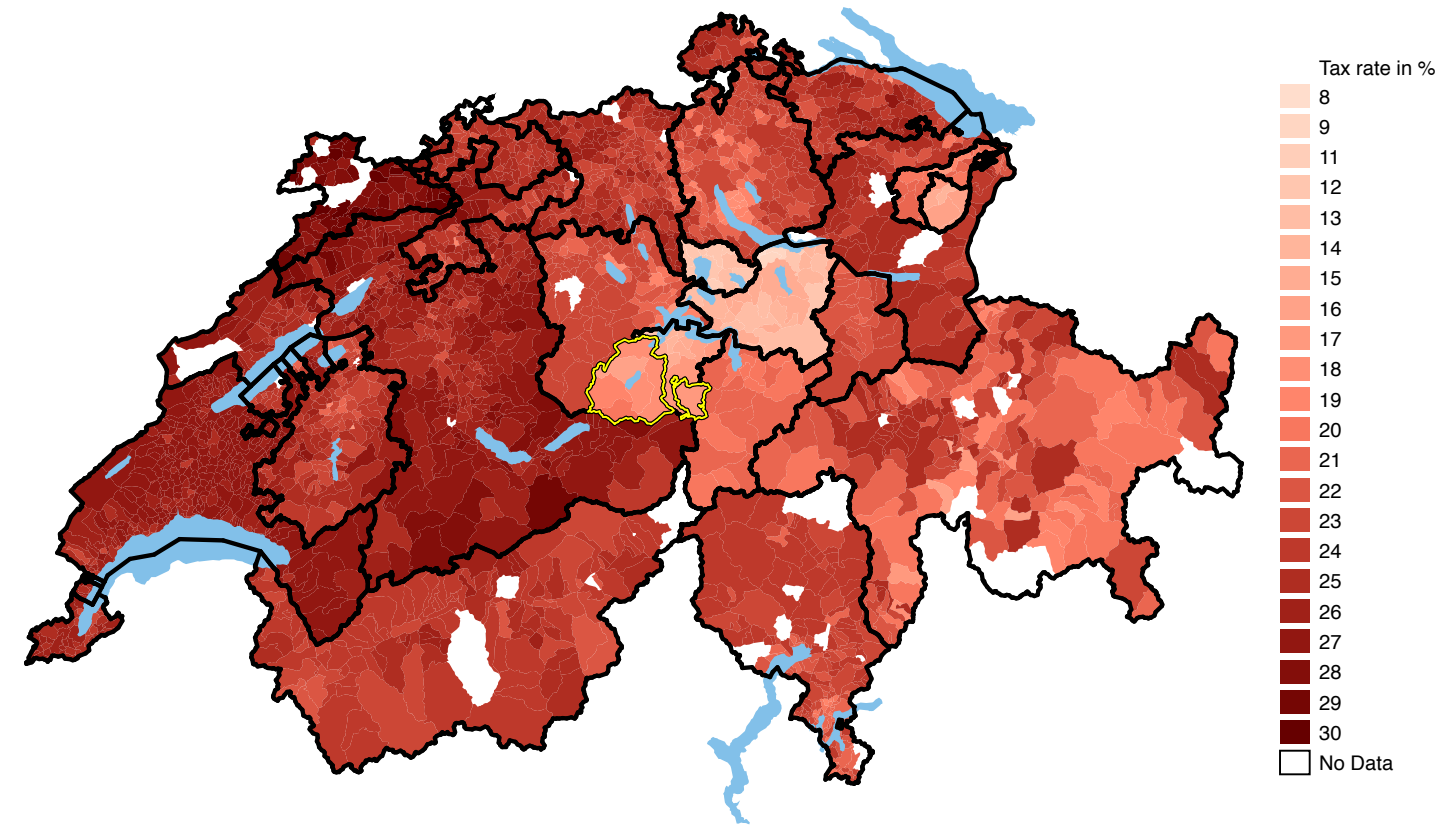

Figure B1: Average income tax for single taxpayer with gross income of 500,000 CHF

Note: Gross labor income net of social security contributions. Average tax load from cantonal, municipality and church taxes. Obwalden is the yellow-rimmed canton in the center of Switzerland.

Source: Tax rates courtesy of Raphaël Parchet (2012); geo-data provided by the Federal Statistical Office, Neuchâtel. 


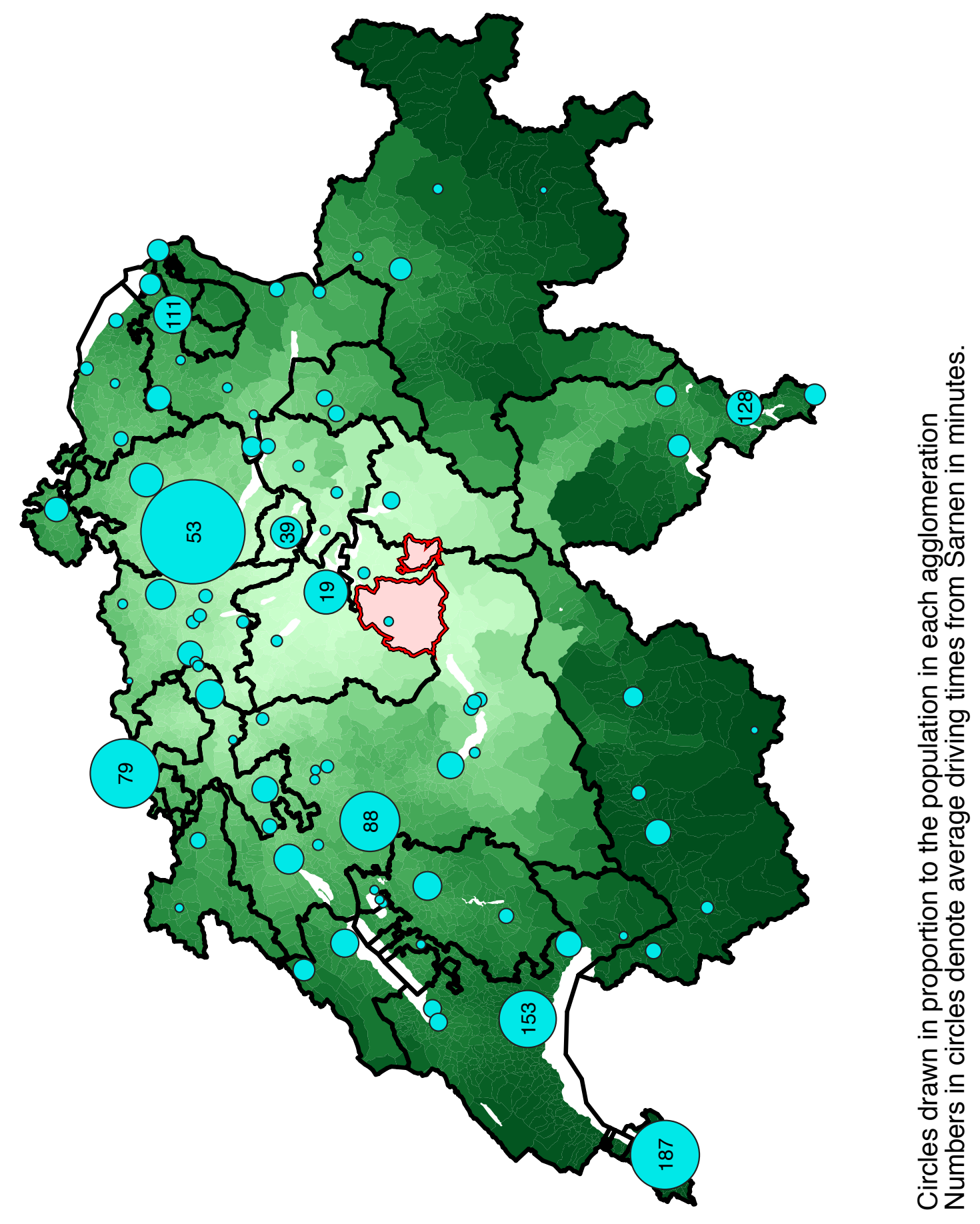

Figure B2: Commuting distances from Sarnen (OW), and urban agglomerations 

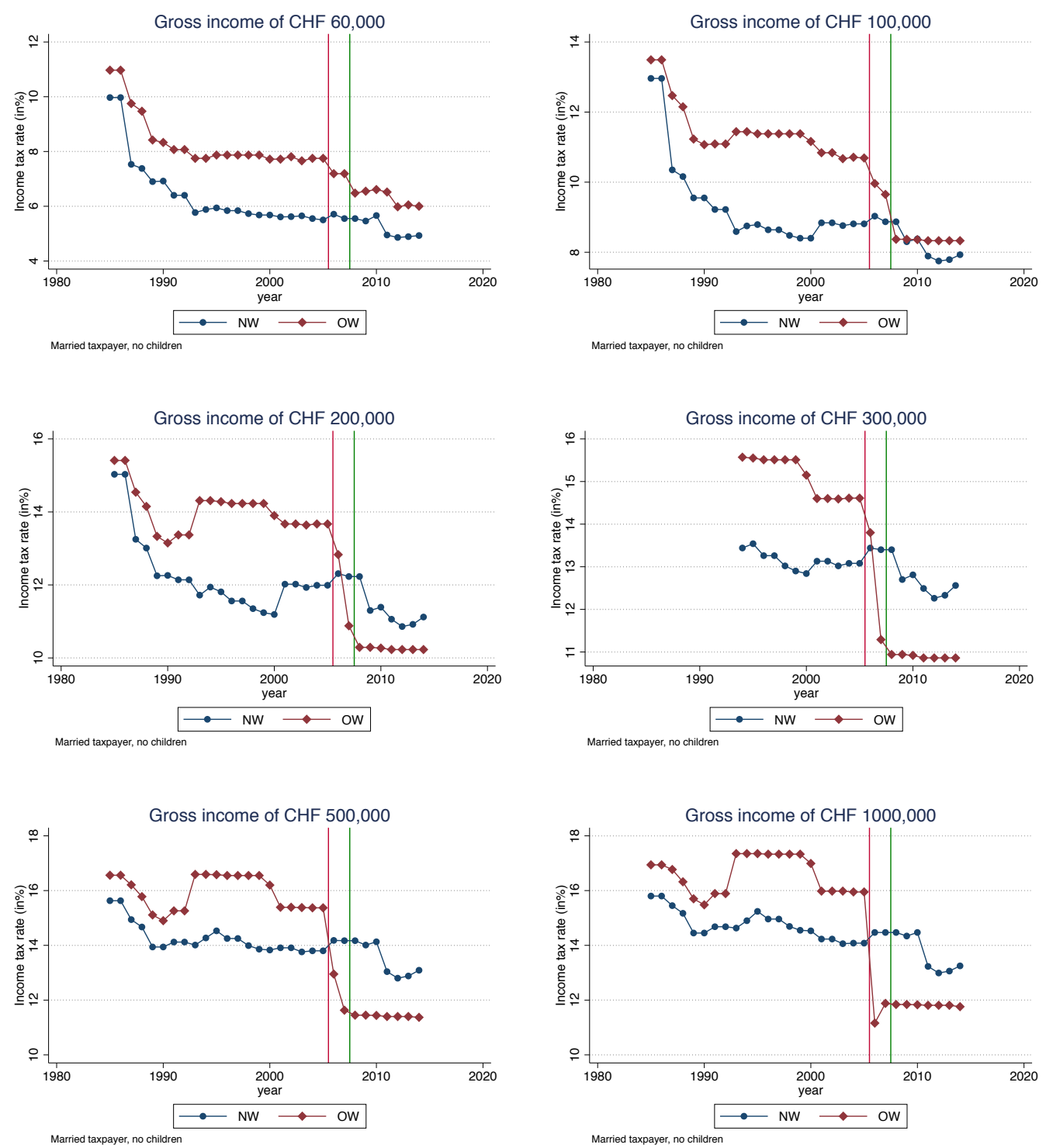

Figure B3: Average income tax rates at gross income levels in Obwalden and Nidwalden

Note: Average tax rates on gross income for a married couple with no children as published by the Federal Tax Administration ESTV, Bern. Tax rates refer to the the average cantonal and municipality tax in the main city of each canton, i.e. Sarnen in Obwalden and Stans in Nidwalden. 

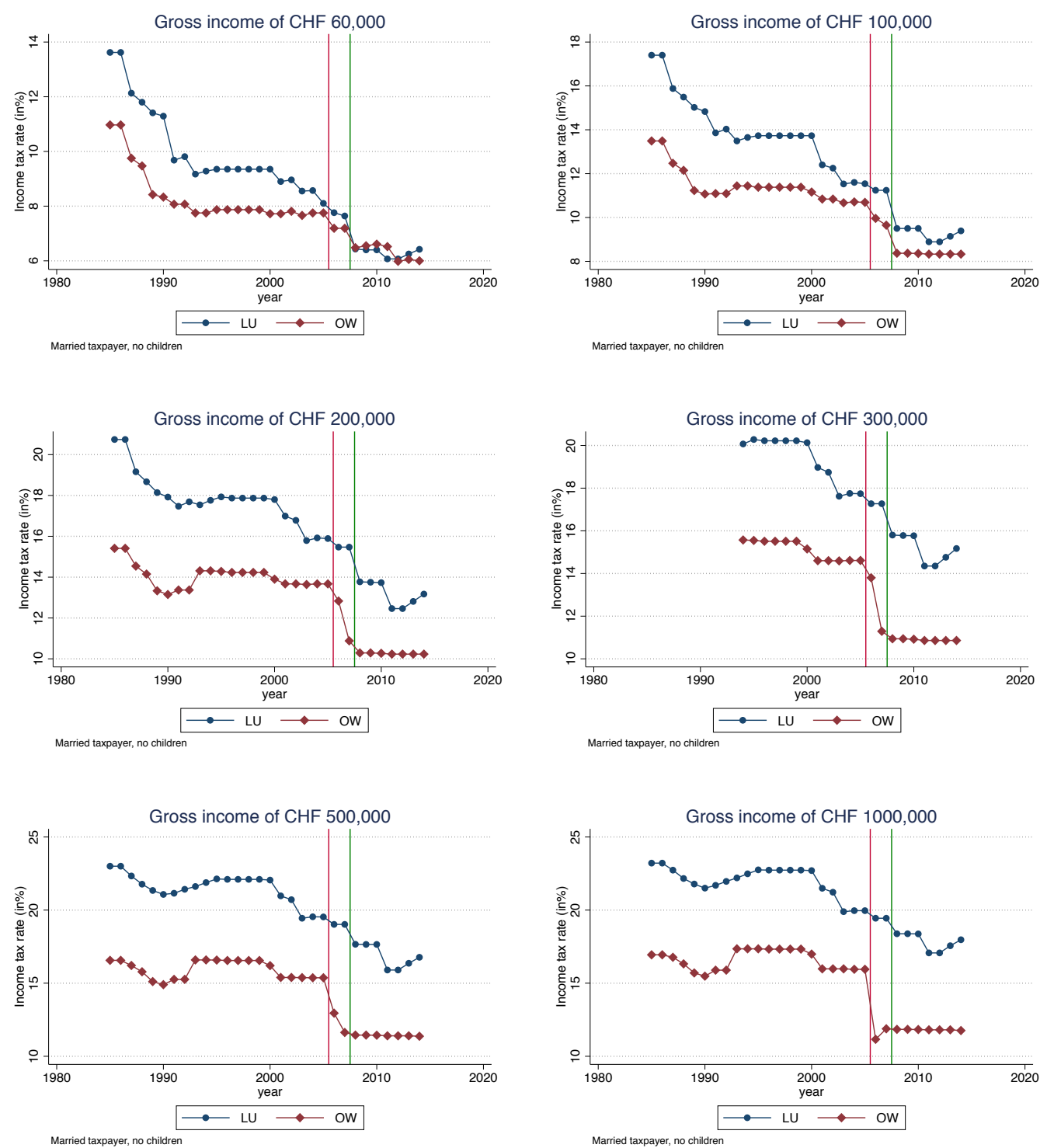

Figure B4: Average income tax rates at gross income levels in Obwalden and Lucerne

Note: Average tax rates on gross income for a married couple with no children as published by the Federal Tax Administration ESTV, Bern. Tax rates refer to the the average cantonal and municipality tax in the main city of each canton, i.e. Sarnen in Obwalden and Lucerne in Lucerne. 


\section{Abbreviations}

List of Cantons

ZH Zurich

SH Schaffhausen

BE Bern

AR Appenzell Ausserrhoden

LU Lucerne

AI Appenzell Innerrhoden

UR Uri

SG St. Gallen

SZ Schwyz

GR Grisons

OW Obwalden

AG Aargau

NW Nidwalden

TG Thurgau

GL Glarus

TI Ticino

ZG Zug

VD Vaud

FR Fribourg

SO Solothurn

BS Basel-Stadt

BL Basel-Landschaft

VS Valais

NE Neuchâtel

GE Geneva

JU Jura

\section{Acronyms}

2SLS Two-Stages Least Squares

DiD Difference-in-Differences

ETI Elasticity of taxable income 